\title{
THE NEED FOR A STRUCTURED APPROACH TO EXTRADITION BETWEEN CHINA AND NEW ZEALAND
}

by

Joseph Griffiths

A thesis submitted to Victoria University of Wellington in fulfilment of the requirements for the degree of a Master of Laws by thesis

\section{FACULTY OF LAW}

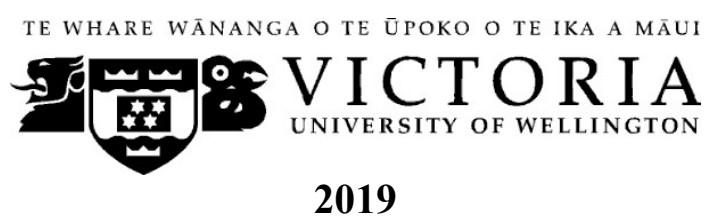




\begin{abstract}
New Zealand will increasingly be confronted with human rights issues arising from the extradition of individuals to China due to perceived inadequacies in China's criminal justice system and the practice of using force to extract confessions by China's law enforcement agencies. This thesis examines the failings of New Zealand's current ad hoc extradition system with its reliance on diplomatic assurances to guarantee fair trial rights and protection against torture for individuals extradited to China. Due to these inadequacies it is possible that the only way in which New Zealand can fulfil its obligations under the United Nations Convention against Corruption in cases involving corruption is for New Zealand to exercise its extraterritorial jurisdiction as an alternative to extradition. The Law Commission's approach in its 2016 report recommending changes to the Extradition Act 1999 fails to comprehend the essential role bilateral treaties are likely to play in terms of New Zealand's extradition relationships with countries such as China in the future. It is argued that a more structured approach is needed by concluding a legally binding treaty with China that provides for specific human rights guarantees and a monitoring regime. This treaty should also allow either state party to offer to try an individual sought for extradition by exercising the requested party's extraterritorial jurisdiction as an alternative to extradition. Furthermore, consideration should be given to expanding the scope of New Zealand's extraterritorial criminal jurisdiction in cases involving individuals requested for extradition under the treaty.
\end{abstract}

\title{
Word length
}

The text of this thesis (including the appendices, bibliography, abbreviations and acronyms, abstract, and table of contents) comprises 49,980 words.

\section{Subjects and Topics}

Extradition law, China, bilateral extradition treaty, Extradition Act 1999, extraterritorial jurisdiction, mutual legal assistance, diplomatic assurances, United Nations Convention against Corruption. 


\section{Contents}

I

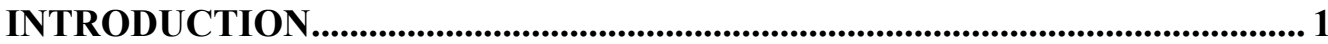

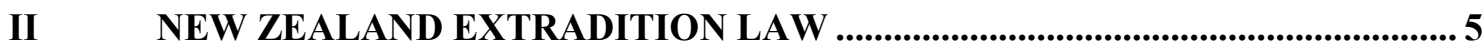

A Extradition Requests under the Extradition Act 1999 ..................................................5 5

1 Procedure for issuing a warrant and subsequent arrest............................ 6

2 Procedure following arrest ........................................................................... 7

$3 \quad$ Determining eligibility for surrender......................................................... 8

$4 \quad$ Deciding whether an individual should be surrendered .............................. 9

B Grounds for Refusing Surrender under the Extradition Act 1999 ........................ 10

1 Mandatory grounds for refusing surrender under section 7 ................... 10

2 Discretionary grounds for refusing surrender under section 8 .............. 13

$3 \quad$ Minister's mandatory grounds for refusal under section 30 ................... 14

$4 \quad$ Minister's discretionary grounds for refusal under section 30 ............... 16

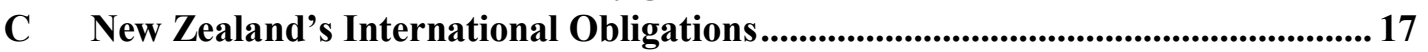

1 New Zealand's multilateral obligations ......................................................... 17

2 Convention against Torture and Other Cruel, Inhuman or Degrading Treatment or Punishment......................................................... 17

3 International Covenant on Civil and Political Rights ............................... 18

$4 \quad$ United Nations Convention against Corruption ....................................... 19

$5 \quad$ Other multilateral agreements involving extradition................................ 21

III CASE STUDY: KYUNG YUP KIM..................................................................... 22

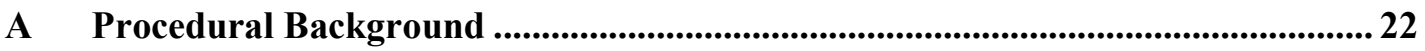

B Relevant Country Information .......................................................................... 23

C High Court Decisions: Kyung Yup Kim v Minister of Justice................................ 29

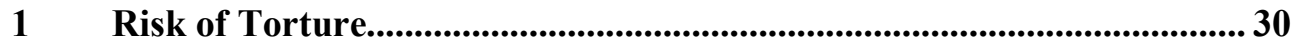

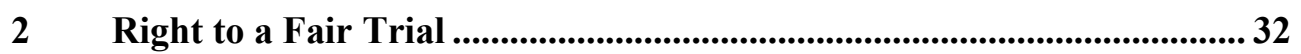

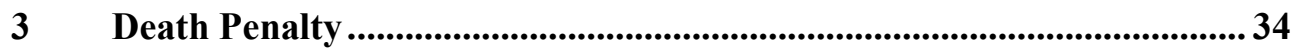

D Court of Appeal Decision: Kyung Yup Kim v Minister of Justice .......................... 35

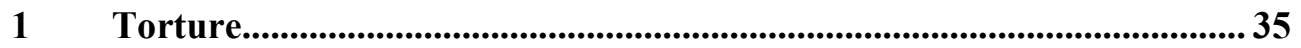

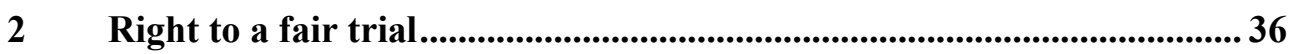

3 Account for time spent in custody pending trial.........................................40

E Diplomatic Assurances ....................................................................................................... 40

IV XI JINPING'S ANTI-CORRUPTION CAMPAIGN, CHINESE COMMUNIST PARTY FACTIONALISM AND EXTRADITION FROM NEW ZEALAND TO CHINA ................................................................................. 44

A The Underlying Motivation for Xi Jinping's Anti-Corruption Campaign ............ 44

B Factional Rivalry in the Chinese Communist Party in the Era of President

$\mathrm{Xi}$

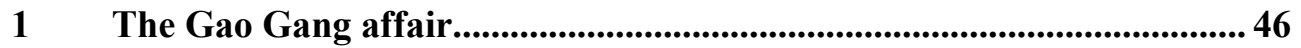

2 The purging of $\mathrm{Hu}$ Yaobang................................................................ 47

C Factionalism and the Prosecution of Bo Xilai for Corruption ................................... 48

D Anti-corruption Campaign under President Xi Jinping ......................................49

E Unilateral Persuasion by China's Security Organs ................................................5 51

F Extradition from New Zealand to China and Xi Jinping's Anti-Corruption

Campaign .................................................................................................................................5 52 
1 China's extraterritorial jurisdiction in criminal matters .......................56

2 New Zealand's extraterritorial jurisdiction in criminal matters ............ 56

3 Interrelationship between extraterritorial jurisdiction and extradition .........................................................................................................6 60

$4 \quad$ Competing jurisdictions and offending on the internet ............................62 62

5 Extraterritorial prosecutions and human rights issues...........................6 64

6 Provision of an alternative to extradition in certain cases ........................ 68

B China and New Zealand's Mutual Assistance in Criminal Matters........................ 69

1 Treaty between New Zealand and the People's Republic of China on Mutual Legal Assistance in Criminal Matters....................................... 70

2 Mutual assistance in criminal matters with China and the risk of

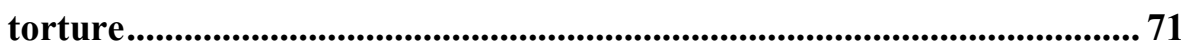

C Aut Dedere Aut Judicare Clause ................................................................................... 74

VI THE IMPACT OF THE LAW COMMISSION'S RECOMMENDATIONS ON EXTRADITION PRACTICE BETWEEN CHINA AND NEW

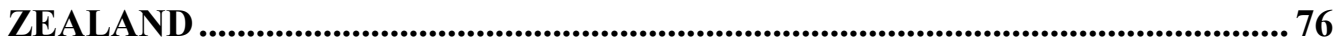

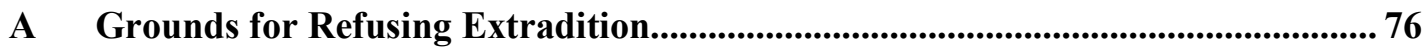

1 Grounds for the court to refuse extradition ............................................. 77

2 Grounds for the Minister to refuse extradition............................................. 78

B Procedural Changes.............................................................................................................. 79

C Further Codification of the Practice of Seeking Diplomatic Assurances.............. 80

D The Law Commission's Approach to the Role of Bilateral Treaties....................... 81

1 Section 11 of the Extradition Act 1999 .................................................... 81

2 The Law Commission's recommendation in respect of bilateral

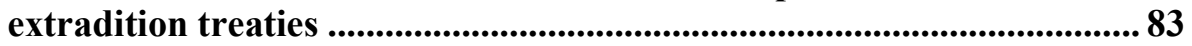

3 The Law Commission's approach to bilateral extradition treaties........ 84

E The Essential Role of Bilateral Extradition Treaties in New Zealand's Extradition Relationships with Countries such as China ........................................86

VII TOWARDS CONCLUDING AN EXTRADITION TREATY WITH CHINA.... 88

A Analysis of Extradition Treaties between China and other Developed Nations

1 Extradition Treaty between the People's Republic of China and the Kingdom of Spain .................................................................................................. 89

2 Treaty between the Portuguese Republic and the People's Republic of China on Extradition .................................................................................... 90

3 Extradition Treaty between the French Republic and the People's Republic of China.

4 Extradition Treaty between the People's Republic of China and the Italian Republic ....................................................................................................... 91

5 Treaty on Extradition between Australia and the People's Republic

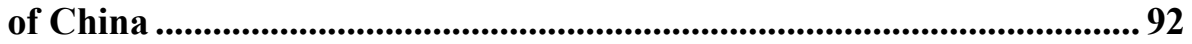

B The Need for an Unconventional Extradition Treaty with China .......................... 96

C Proposals for an Extradition Treaty between New Zealand and China ................ 98

1 Incorporation of international treaties into China's domestic law ........ 99 
2 Proposed human rights protections under the treaty........................... 101

3 Proposed grounds for refusing surrender ............................................ 103

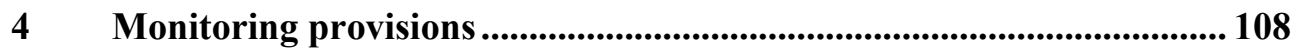

5 Taking account of pre-trial detention at sentencing.............................. 108

6 Aut dedere aut judicare - obligation to exercise extraterritorial jurisdiction ..................................................................................................... 109

$7 \quad$ Termination and suspension.......................................................................... 109

VIII CONCLUSION: THE NEED FOR A STRUCTURED APPROACH TO EXTRADITION BETWEEN CHINA AND NEW ZEALAND ............................. 111

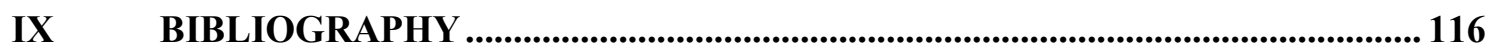

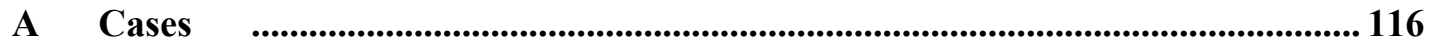

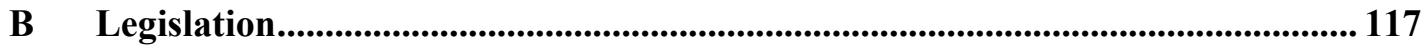

C Treaties and Model Treaties .............................................................................. 118

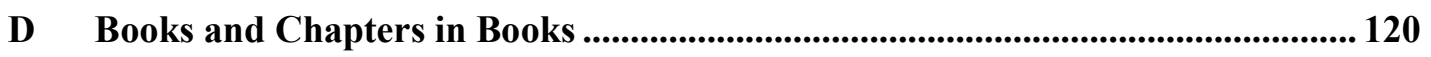

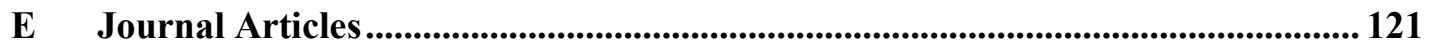

F Parliamentary and Government Materials ........................................................... 123

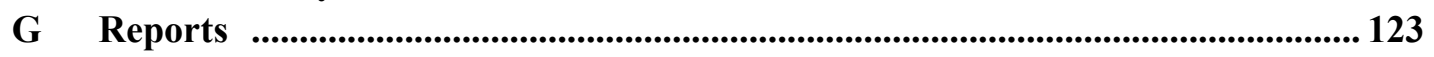

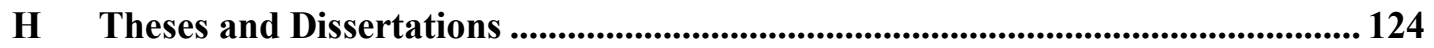

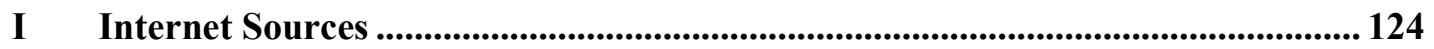

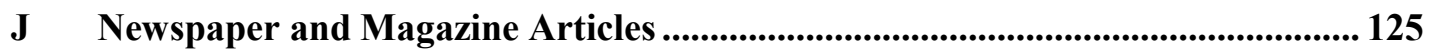

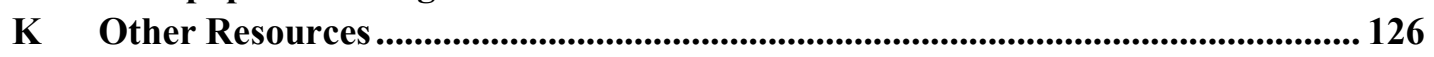

Appendix 1................................................................................127

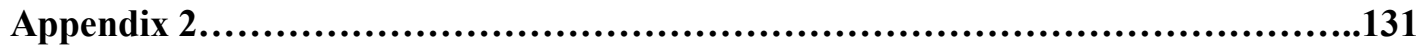




\section{Abbreviations and Acronyms}

AGM

CAT

CCDI

CCP

CL

CPL

DEA

ECHR

ECtHR

EL

ICCPR

ICJ

JSCOT

LCA

MACMA

MFAT

MOU

NZBORA

OIA

SPC

UNCAC

UNTOC

VCLT
Australian Attorney-General's Department

Convention against Torture and Other Cruel, Inhuman or

Degrading Treatment or Punishment

Central Commission for Discipline Inspection

Communist Party of China

Criminal Law of the People's Republic of China

Criminal Procedure Law of the People's Republic of China 2012

Drug Enforcement Administration

European Convention on Human Rights

European Court of Human Rights

Extradition Law of the People's Republic of China

International Covenant on Civil and Political Rights

International Court of Justice

Joint Standing Committee on Treaties - Parliament of Australia

Law Council of Australia

Mutual Assistance in Criminal Matters Act 1992

Ministry of Foreign Affairs and Trade

Memorandum of Understanding

New Zealand Bill of Rights Act 1990

Official Information Act 1982

Supreme People's Court of the People's Republic of China

United Nations Convention against Corruption

United Nations Convention against Transnational Organised

Crime

Vienna Convention on the Law of Treaties 


\section{Introduction}

China $^{1}$ is increasingly seeking bilateral extradition agreements and the extradition of individuals accused of criminal offending in China as part of its far-reaching campaign against corruption, particularly in relation to alleged corruption by Chinese government officials who have fled to other jurisdictions. At the same time, crime in New Zealand is increasingly taking on an international dimension. This means that New Zealand will increasingly be confronted with human rights issues arising from the extradition of individuals to China due to perceived inadequacies in China's criminal justice system and the practice of using force to extract confessions by China's law enforcement agencies despite efforts to deter this practice. This is especially likely in the absence of a bilateral extradition treaty which provides for specific human rights guarantees.

This thesis will examine these human rights issues and the possibility of an extradition treaty being agreed between the two countries to address these problems. This will encompass consideration of what should be included in a bilateral agreement with China and whether the current system, with its reliance on ad hoc assurances and reciprocity, will provide adequate human rights protections for the foreseeable future. It is argued that a binding bilateral agreement, providing a structured legal framework and monitoring regime, must be agreed in order for New Zealand to meet its human rights obligations when extraditing individuals to China in the future. This would provide more certainty and specificity than the current system, and potentially reduce delay by averting the need to negotiate assurances on a case-by-case basis.

Chapter II examines current extradition law and procedure in New Zealand under the Extradition Act 1999 (NZ) focusing on extradition from New Zealand to China. This will involve an overview of New Zealand's extradition system, namely how requests are processed, the grounds for refusing requests and New Zealand's international obligations preventing the surrender of an individual to China when there is a risk that that individual will be executed, subject to torture or inhuman treatment, or deprived of fair trial rights. This chapter will also examine some of the international instruments which place an obligation on New Zealand to extradite individuals accused of committing particular kinds of offending.

Chapter III will undertake a case study of the extradition of Kyung Yup Kim a Korean citizen and New Zealand permanent resident accused of murdering a woman in Shanghai

${ }^{1}$ All references to China in this thesis are references to the People's Republic of China. 
in 2009. This is the first and only time China has requested the extradition of an individual from New Zealand. This case demonstrates the international human rights issues that arise when extraditing an individual from New Zealand to China and the many inadequacies of the ad hoc process for extradition currently applied between the two countries. This chapter necessarily encompasses a short overview of China's criminal justice system and the human rights issues that arise as a result of extradition of an individual to ultimately stand trial in China. It is clear that China hopes to set a precedent by way of Kim's extradition proceedings paving the way for it to seek the extradition of so called "economic fugitives" who are alleged to be residing in New Zealand. Kim's extradition was approved by the High Court in August 2017. The Court of Appeal overturned this decision on appeal in June 2019 remitting Kim's case back to the Minister of Justice to reconsider whether to surrender Kim for extradition. There is currently only uncertainty as to whether China can successfully seek extradition of an individual from New Zealand under the current ad hoc system with its reliance on non-binding diplomatic assurances to protect against torture and ensure fair trial rights.

Chapter IV examines President Xi Jinping's global anti-corruption campaign, the driving force behind China's desire to extradite individuals who have allegedly fled abroad to escape prosecution for crimes committed in China. This will involve an analysis of the murky world of factional rivalry within the Chinese Communist Party (CCP) and how Xi Jinping's anti-corruption campaign appears to have been utilised to suppress political rivals. This analysis indicates that even if China one day succeeded in obtaining the extradition of an ordinary criminal suspect like Kim, the Chinese government would still find it almost impossible to successfully extradite a 'high profile' individual accused of economic crimes under the current ad hoc extradition process. Even a bilateral extradition treaty may not be sufficient to safely extradite such individuals. This is due to both the high risk of political interference in court proceedings involving such 'high profile' individuals and the increased risk of these individuals being subject to torture by the CCP's highest internal disciplinary agency, the Central Commission for Discipline Inspection (CCDI). This may mean, that for cases involving high profile individuals, the only way New Zealand can meet its obligations under UNCAC is to conclude a bilateral agreement allowing New Zealand to initiate an extraterritorial prosecution in the event that New Zealand declines to extradite such an individual.

Chapter V examines both China and New Zealand's extraterritorial jurisdictions in respect of criminal offending and mutual assistance between the two countries in criminal matters. This chapter looks at whether New Zealand could better address its human rights 
obligations while playing its part in combatting international crime by exercising its extraterritorial jurisdiction over an individual sought by China for extradition instead of granting an extradition request. This chapter also argues that any extradition treaty signed with China should include a comprehensive asset sharing regime. The analysis in this chapter traverses some of the issues that arise when exercising a country's extraterritorial jurisdiction, such as when jurisdictions compete for jurisdiction over offending that has been facilitated by the internet and issues that arise with respect to mutual legal assistance and equality of arms when instituting extraterritorial prosecutions. This chapter then goes on to undertake an analysis of how mutual legal assistance requests to China could place such individuals at risk of being subject to torture, particularly in respect of requests for the attendance of individuals resident in China to give evidence in New Zealand.

Chapter VI comprises an analysis of the Law Commission's recommendations ${ }^{2}$ for modernising New Zealand's extradition law and what the recommendations mean for China and New Zealand's current extradition relationship. Notably, the recommendations do not address the intrinsic problems arising from reliance on diplomatic assurances to address human rights concerns. Instead, the Commission's primary focus is on the implementation of a streamlined version of the current ad hoc process. Although extradition will continue to be possible without an extradition treaty under the proposed law, the Commission's approach essentially relegates extradition treaties to a supplementary role unable to derogate from the proposed law's 'baseline requirements'. This chapter considers how the Law Commission's recommendations do not address the problems with the current ad hoc process and how the Commission's view regarding the supplementary nature of bilateral extradition treaties fails to comprehend the essential role bilateral treaties could play with respect to New Zealand's extradition relationship with countries such as China in the future.

Chapter VII undertakes an exploration of what should be included in a bilateral agreement with China through a short analysis of the bilateral extradition treaties China has signed with other developed nations. This chapter explores in which ways a binding treaty with China would provide better human rights protections for the foreseeable future than the current and recommended approaches, with their reliance on ad hoc assurances and reciprocity. It examines how a more structured approach will be necessary to better address the human rights issues associated with extraditing individuals to and from China. It is argued that a binding bilateral agreement, containing specific human

${ }^{2}$ Law Commission Modernising New Zealand's Extradition and Mutual Assistance Laws (NZLC R137, 2016). 
rights guarantees and a monitoring regime, would not only provide more certainty and specificity than the current system, but also provide New Zealand with a means by which to enforce assurances after extradition has occurred through the use of countermeasures such as suspension and termination of the treaty.

Chapter VIII concludes by arguing that a binding bilateral extradition treaty between New Zealand and China is necessary to ensure that New Zealand continues to meet its international obligations while at the same time playing its part in combatting transnational crime now and into the future. However, a treaty following the traditional model similar to the United Nations Model Treaty on Extradition and the model adopted by other developed countries which have signed agreements with China would do little more than incorporate into the current extradition system an obligation for New Zealand to extradite suspects to China. This is because the imposition of an extradition treaty that follows the traditional model would do nothing to remove New Zealand's reliance on diplomatic assurances to ensure that New Zealand adheres to its international obligations when extraditing an individual to China. 


\section{New Zealand Extradition Law}

Before embarking on an analysis of the benefits a bilateral extradition treaty would bring to the extradition relationship between China and New Zealand, it is necessary to fully understand how the current extradition system functions. What follows is an analysis of the current extradition system as it relates to extradition from New Zealand to China, including a short analysis of its historical origins.

\section{A Extradition Requests under the Extradition Act 1999}

The Extradition Act 1999 applies to extradition requests made by New Zealand to other countries and from other countries to New Zealand. It provides both the procedure and the terms on which extradition can occur. However, an extradition treaty with a foreign country can both complement and to some extent supersede the provisions of the Act. The Act provides for two different procedures for extradition from New Zealand, depending on which county makes a request. The standard procedure, under Part 3 of the Act, applies to extradition requests from a Commonwealth country, a country with which there is a bilateral treaty, a country designated by Order in Council to have Part 3 apply and an individual request by a country under Part 5 of the Act. ${ }^{3}$ The back-warranted procedure, in Part 4 of the Act, is a fast-track procedure which only applies to Australia and any country designated by Order in Council, currently the United Kingdom, including the Pitcairn Islands. ${ }^{4}$ This thesis will focus on the standard procedure as it applies to requests from China under Part 3 of the Act. The Minister has a fairly broad discretion whether to designate China's request under the Act, ${ }^{5}$ meaning that it would be a rare occurrence for the Minister not to allow a request from China to be dealt with under the Act.

The standard procedure under Part 3 has four stages: ${ }^{6}$

(a) issuing a warrant and arresting the individual subject to the request;

(b) bringing the individual before the court as soon as possible;

(c) determining the eligibility of the individual for extradition; and

\footnotetext{
${ }^{3}$ Extradition Act 1999, s 13.

${ }^{4}$ Section 39.

${ }^{5}$ Section 60(3).

${ }^{6}$ Kyung Yup Kim v Minister of Justice [discharge application] [2016] NZHC 1491 at [19].
} 
(d) deciding whether the individual should be surrendered.

\section{Procedure for issuing a warrant and subsequent arrest}

Essentially, once the Minister has decided that a request from China can be dealt with under the Act, the request proceeds to the first stage. The request must be supported by a copy of a warrant for the arrest of the individual issued in China, a description of the offence, the prescribed penalty for the offence in China and the conduct constituting the offence. In the case of a requested individual who has already been convicted, the request must include a copy of the conviction, the sentence imposed and the extent to which a sentence imposed has not been completed. ${ }^{7}$

The Minister has a discretion as to whether to notify the District Court of the extradition request and make a request that the Court issue a warrant to arrest the subject of the extradition request and bring the individual before the Court. ${ }^{8}$ The Minister may decline to notify the District Court. ${ }^{9}$ There are no grounds provided by the Act on which the Minister is to make this decision. ${ }^{10}$ If the Minister decides to notify the District Court, the District Court Judge has a discretion as to whether to issue a warrant for the individual's arrest. The Judge must be satisfied that the individual is, or is suspected of being, in New Zealand or on his or her way to New Zealand and there are reasonable grounds to believe that the individual is an extraditable person, China is an extradition country and the offence is an extraditable offence under the Act. ${ }^{11}$ In the case of a request made by China, an extraditable person is an individual who is accused of having committed or has been convicted of an extradition offence against the law of China. ${ }^{12}$ An extradition country is one to which the Act applies. ${ }^{13}$ As the Minister will have decided that the Act applies to the request before deciding to notify the District Court, China would be deemed to be an extradition country. An extradition offence is an offence under the law of China, if the same criminal conduct constituting that offence, would also constitute an offence, if proven to have occurred within the jurisdiction of New Zealand at the time the conduct is alleged to have occurred in China; and the offences for the relevant conduct in both

\footnotetext{
${ }^{7}$ Extradition Act 1999, s 18(4).

${ }^{8}$ Section 19(1).

${ }^{9}$ Section 19(3).

${ }^{10}$ Law Commission Extradition and Mutual Assistance in Criminal Matters (NZLC IP37, 2014) at 17.

${ }^{11}$ Extradition Act 1999, s 19(2).

12 Section 3.

${ }^{13}$ Section 2.
} 
jurisdictions are punishable by a maximum penalty of not less than 12 months' imprisonment. This definition of an extradition offence is subject to any definition within any applicable treaty. ${ }^{14}$

The District Court also has the power to issue a provisional warrant if China makes an urgent request without supporting documentation, or without making a request for surrender to the Minister and subsequent notification from the Minister to the District Court. In addition to the same matters outlined above for non-provisional warrant requests, in the case of urgent requests, the District Court Judge must also be satisfied that it is necessary or desirable for an arrest warrant to be issued urgently. ${ }^{15}$ If a provisional warrant is issued, the applicant for the warrant must report this fact to the Minister. ${ }^{16}$ The report must include a copy of the warrant issued in China and the other documentary evidence provided to the Court when applying for the warrant. ${ }^{17}$ On receipt of the report, the Minister, if he or she thinks fit, may order the discontinuance of the extradition proceedings. ${ }^{18}$ This is discretionary as there are no grounds provided under the Act for making a decision to discontinue the proceedings at this stage. If the Minister orders such, the Minister may cancel the warrant and order the release of any individual arrested under the warrant. ${ }^{19}$ The proceedings against an individual subject to a provisional warrant cannot proceed until the Minister notifies the Court that a request for the individual's surrender has been transmitted to him or her. ${ }^{20}$ Therefore, the supporting documentation usually supplied with a non-provisional warrant must be provided to the Minister within a reasonable time before the following stages of the extradition process can proceed. ${ }^{21}$ If the Court does not receive the notice from the Minister within a reasonable time, the Court must discharge the individual. ${ }^{22}$

\section{Procedure following arrest}

An individual arrested under a warrant, whether provisional or not, unless already discharged, must be brought before a court as soon as possible. ${ }^{23}$ Such an individual is

\footnotetext{
${ }^{14}$ Section 4.

${ }^{15}$ Section 20.

${ }^{16}$ Section 21(1).

${ }^{17}$ Section 21(2).

${ }^{18}$ Section 21(3).

${ }^{19}$ Section 21(4).

${ }^{20}$ Section 23(4)(a).

${ }^{21}$ Law Commission, above n 10, at 17.

${ }^{22}$ Extradition Act 1999, s 23(4)(c).

${ }^{23}$ Section 23(1).
} 
not bailable as of right and may only be released on bail. ${ }^{24}$ The provisions of the Bail Act 2000 apply but with some modifications. ${ }^{25}$ The individual must be released on reasonable terms and conditions unless the Court is satisfied there is just cause for continued detention. $^{26}$ The onus to show just cause for continued detention is on the party seeking the individual's extradition. The Court must take into account a number of factors when considering whether there is just cause for continued detention. ${ }^{27}$ Usually, the most relevant consideration in extradition cases will be the particular individual's flight risk. If bail is declined, the Court has the power to detain the individual pending disposition of the proceedings. ${ }^{28}$

\section{Determining eligibility for surrender}

Once an individual facing extradition has been detained subject to an arrest warrant and either remanded in custody or on bail, the District Court must subsequently decide if the individual is eligible for surrender. The Court must be satisfied that the necessary documentation has been produced to the Court, that the alleged offending constitutes an extradition offence and that the evidence given at the hearing would justify the individual's trial if the conduct constituting the offence had occurred within New Zealand's jurisdiction. ${ }^{29}$ The onus is on China, the party seeking extradition, to satisfy the Court of these matters. ${ }^{30}$ In respect of the evidence provided to the Court, the onus is on China to satisfy the Court that there is a prima facie case. ${ }^{31}$ This means that the Court must determine whether a properly directed jury could convict the individual on the evidence. $^{32}$ The Court must also consider whether any mandatory or discretionary restrictions on surrender apply. If the Court is satisfied that any restrictions apply, the individual will not be eligible for surrender. ${ }^{33}$ The onus is on the individual facing extradition to satisfy the Court that a mandatory or discretionary restriction applies. ${ }^{34}$

\footnotetext{
${ }^{24}$ Section 23(2).

25 Section 22(1)(b)(ii). Interestingly, none of the reverse onus restrictions of the Bail Act, including restrictions for a person charged with murder, apply to an individual facing extradition, except for the restriction relating to class A drug offending, which was inserted into the Bail Act in 2013.

${ }^{26}$ Bail Act 2000, s 7(5).

27 Section 8.

${ }^{28}$ Kyung Yup Kim v The Prison Manager Mt Eden Correctional Facility [2012] NZCA 471, [2012] 3 NZLR 845.

${ }^{29}$ Extradition Act 1999, s 24(2).

${ }^{30}$ Kyung Yup Kim v The Prison Manager, Mt Eden Corrections Facility, above n 28, at [25].

${ }^{31}$ Dotcom v United States of America [2014] NZSC 24, [2014] 1 NZLR 355 at [184].

${ }^{32}$ Criminal Procedure Act, s 147(4)(c).

${ }^{33}$ Extradition Act 1999, s 24(3).

${ }^{34}$ Kyung Yup Kim v The Prison Manager, Mt Eden Corrections Facility, above n 28.
} 
If the Court is not satisfied that the individual is eligible for surrender, it must discharge and release the individual from custody unless the Court is notified of an intention to appeal the determination. ${ }^{35}$ The matter will not proceed to be considered by the Minister if the Court makes such a determination, unless the Court's decision is overturned on appeal. If the Court determines that the individual is eligible for surrender, the Court must issue a warrant for the detention of the individual pending the individual's surrender or discharge. ${ }^{36}$ The Court must also make a written record of the extradition offence to which the individual is eligible for surrender ${ }^{37}$ and then send a copy of that written record, the warrant and a report regarding the case to the Minister, including a copy of the application and any evidence that was before the Court. ${ }^{38}$ The Court must also inform the individual that he or she will not be extradited within 15 days of the issue of the warrant and the individual's right to make an application for writ of habeas corpus and lodge an appeal. ${ }^{39}$ The Court may reconsider whether to grant the individual bail pending surrender. ${ }^{40}$

\section{Deciding whether an individual should be surrendered}

The issuing of a warrant by the District Court to the Minister on a finding of eligibility for surrender triggers the fourth stage of the process. The Minister must decide whether the requested individual should be surrendered to China, even if the individual consents to being surrendered. ${ }^{41}$ The Act sets out the mandatory and discretionary grounds for declining to surrender an individual. ${ }^{42}$ In considering whether to surrender an individual, the Minister may seek any undertakings from China the Minister thinks fit. If the Minister decides not to order the surrender of an individual, that individual must be released from custody. ${ }^{43}$ If the Minister decides that the individual is to be surrendered, the Minister must make a surrender order in respect of the individual. ${ }^{44}$ Such an order cannot be made until 15 days after the warrant for detention was issued, unless a determination under the Act is subject to an appeal, judicial review or an application for writ of habeas corpus. In

\footnotetext{
${ }^{35}$ Extradition Act 1999, ss 26 and 70.

${ }^{36}$ Section 26(1)(a).

${ }^{37}$ Section 26(1)(b).

${ }^{38}$ Section 26(1)(c).

${ }^{39}$ Section 26(1)(d).

${ }^{40}$ Section 26(2).

${ }^{41}$ Section 30(1).

${ }^{4}$ Sections 7, 8 and 30 .

${ }^{43}$ Section 35.

${ }^{44}$ Section 31(1).
} 
such a case, the Minister must wait until final determination of the relevant proceedings and a finding that the individual is eligible for surrender before making an order. ${ }^{45}$

An individual may also apply to the High Court to be discharged from the extradition proceedings if the individual is not conveyed out of New Zealand under a surrender order two months from the date a warrant for detention is issued. In the event that an individual subject to an extradition request appeals and/or applies for judicial review or a writ of habeas corpus, this date changes until two months after such proceedings are finally determined. An individual can also apply for discharge of the extradition, if the individual has not been conveyed from New Zealand to China within two months from the date a surrender order takes effect. ${ }^{46}$ Once a surrender order is issued, the authorities in New Zealand and China will liaise as to the logistics of transferring the individual to China to face trial. $^{47}$

\section{B Grounds for Refusing Surrender under the Extradition Act 1999}

The Act provides for both mandatory and discretionary grounds for refusing surrender of an individual to China. The mandatory grounds are provided for in section 7, while the discretionary grounds are provided for under section 8 . These grounds are considered by the Court when considering an individual's eligibility for surrender. ${ }^{48}$ The Minister also considers these grounds for refusal when considering whether to surrender an individual. ${ }^{49}$ In addition to the section 7 and 8 grounds, the Minister also takes into consideration a number of other mandatory and discretionary grounds for refusal under s 30 of the Act.

\section{Mandatory grounds for refusing surrender under section 7}

(a) Political offence

Section 7 provides for a mandatory restriction on surrender where the offence for which surrender is sought is an offence of a political character. ${ }^{50}$ There is no definition for what is meant by "political character". The provision has not been considered by the courts in

\footnotetext{
${ }^{45}$ Section 31(2).

${ }^{46}$ Section 36.

${ }^{47}$ Law Commission, above n 10, at 17.

${ }^{48}$ Extradition Act 1999, s 24(3)(a) and (4).

${ }^{49}$ Section 30(2)(a) and (3)(b).

${ }^{50}$ Section 7(a).
} 
New Zealand in the context of an extradition. ${ }^{51}$ However, in the context of an application for recognition of refugee status, the Supreme Court in The Attorney-General (Minister of Immigration) $v$ Tamil $X^{52}$ held that a political offence is one which is motivated by a political objective; although the context, methods, motivation and proportionality of a particular crime will be relevant to the question of whether an offence is of a political character. $^{53}$

This ground for refusing extradition has been around since extradition statutes were first established in the 19th century. The principle underlying such a prohibition is that it is considered inappropriate to suppress resistance to political oppression and nation states should not interfere in the internal political struggles of other states. However, with the advent of international terrorism at the turn of the 21 st century many countries have moved to exclude terrorist acts from the definition of a political offence. Similarly, many multilateral conventions have excluded terrorist offences, crimes against humanity, torture and hostage taking from the exception. ${ }^{54}$ Despite there being no definition under the Act, an orthodox interpretation of the legislation would mean that it is not a country's underlying motivation for seeking a particular individual's extradition that denotes a political character to a particular offence, but the underlying motivations of an individual, subject to extradition proceedings, for committing the offence in question. ${ }^{55}$

(b) Discriminatory motivations for extradition and prosecution

Unlike with the political offence exception above, the first discriminatory ground for refusal is concerned with the requesting country's underlying motivation for extraditing an individual. Section 7 provides that there is a mandatory restriction on extradition where the real motivation behind seeking an individual's extradition is to prosecute or punish that individual on account of his or her race, ethnic origin, religion, nationality, sex, other status, political opinions or for a political offence. ${ }^{56}$ The second discriminatory ground which provides for a mandatory restriction on extradition arises where an individual would be prejudiced in his or her trial or detained by reason of his or her race, ethnic group, religion, nationality, sex, other status or political opinion. ${ }^{57}$ Interestingly,

\footnotetext{
${ }^{51}$ Law Commission, above n 10, at 94.

${ }^{52}$ Attorney-General (Minister of Immigration) v Tamil X [2010] NZSC 107, [2011] 1 NZLR 721.

${ }^{53}$ At [90].

${ }^{54}$ Law Commission, above n 10, at 93-94.

${ }^{55}$ Attorney-General (Minister of Immigration) v Tamil X, above $\mathrm{n}$ 52, at [90].

${ }^{56}$ Extradition Act 1999, s 7(b).

${ }^{57}$ Section 7(c).
} 
this second discriminatory ground does not include prejudice at trial or detention for an offence of a political character. The catch-all "or other status" in the provisions would likely be interpreted to include other common discriminatory exceptions to extradition such as sexual orientation, age, and mental or physical disabilities. In the context of extradition to China, the grounds would require an assessment of the likelihood of the discrimination occurring against an individual after extradition to China. ${ }^{58}$

(c) Military offence

Section 7 provides for a mandatory restriction on extradition where the offence for which extradition is sought is an offence under military law only. This is when the offence is not an offence under the ordinary criminal law of the extradition country. ${ }^{59}$ The rationale behind this exception is that the purpose of extradition arrangements is usually to combat crimes, not enforce foreign military discipline. Accordingly, because military offences that are not also an offence under ordinary criminal law usually relate to disciplinary matters rather than crime, it is widely considered inappropriate for military offences to be the focus of extradition proceedings. ${ }^{60}$

\section{(d) Double jeopardy}

Section 7 provides that it would be a mandatory ground for refusing surrender, if an individual had been acquitted, pardoned, or had already undergone punishment in respect of the extradition offence, or another offence constituting the same conduct as the extradition offence, in either China or New Zealand. ${ }^{61}$ This in in keeping with both New Zealand's domestic human rights law and international human rights law. ${ }^{62}$ However, this ground for refusal does not include the situation where an individual may have been acquitted, pardoned or punished for the offending in another state, which is not party to the extradition proceedings. ${ }^{63}$ Consideration of whether to extradite an individual in these circumstances would require the Minister, when considering any other reasons for refusing surrender under s 30(3)(e) of the Act, to factor in both domestic and international law that prohibits double jeopardy.

\footnotetext{
${ }^{58}$ Law Commission, above $\mathrm{n} 10$, at 95-96.

${ }^{59}$ Extradition Act 1999, s 7(d).

${ }^{60}$ Law Commission, above $\mathrm{n} 10$, at 96.

${ }^{61}$ Extradition Act 1999, s 7(e).

${ }^{62}$ New Zealand Bill of Rights Act 1990 [NZBORA], s 26(2) and the International Covenant on Civil and Political Rights 999 UNTS 171 (opened for signature 16 December 1966, entered into force 23 March 1976) [ICCPR], art 14(7).

${ }^{63}$ Law Commission, above n 10, at 97-98.
} 
(e) Detention due to mental health or intellectual disability

Section 7 provides for a mandatory restriction on surrender where an individual is already being detained in New Zealand as a special patient under the Mental Health (Compulsory Assessment and Treatment) Act 1992 or in a facility as a special care recipient under the Intellectual Disability (Compulsory Care and Rehabilitation) Act 2003. ${ }^{64}$ This covers the situation where an individual has been found unfit to stand trial or acquitted on account of insanity by the New Zealand courts in respect of related or unrelated offending. ${ }^{65}$ The principle behind this mandatory restriction appears to be the need to protect an individual from extradition, where it is considered inappropriate to prosecute or punish that individual in New Zealand. However, this ground only covers a situation where an individual has already been prosecuted for offending in New Zealand and does not include circumstances where an individual has not committed an offence in New Zealand, but the individual's mental health or intellectual disability is such that extradition should nevertheless be considered inappropriate. ${ }^{66}$

\section{Discretionary grounds for refusing surrender under section 8}

(a) Triviality, bad faith and delay

Section 8 of the Act provides for three discretionary grounds for refusing extradition. This is where it would be unjust or oppressive to surrender an individual because of the trivial nature of the case; or because the allegations made against the individual are not made in good faith in the interests of justice; or due to the amount of time that has passed since the offence occurred or is alleged to have occurred. ${ }^{67}$ The provision provides the Minister or the Court with a means by which to consider the particular circumstances of an individual's case, but confines that enquiry to just these three grounds. ${ }^{68}$

\section{(b) Prosecution in New Zealand}

Section 8 also provides a discretionary ground for refusing surrender where the individual subject to extradition proceedings has been accused of committing an offence in New

\footnotetext{
${ }^{64}$ Extradition Act 1999, s 7(f) and 7(g).

${ }^{65}$ Criminal Procedure (Mentally Impaired Persons) Act 2003, s 24.

${ }^{66}$ Law Commission, above $n$ 10, at 98-99.

${ }^{67}$ Extradition Act 1999, s 8(1).

${ }^{68}$ Law Commission, above n 10, at 99-100.
} 
Zealand and the proceedings relating to that offence have not been concluded. The offence the individual has been accused of committing must not be the offence for which the individual's surrender is sought. ${ }^{69}$ This provision is peculiar to New Zealand as other comparable jurisdictions do not provide for this ground in their extradition law. ${ }^{70}$

\section{Minister's mandatory grounds for refusal under section 30}

(a) Any mandatory restriction under a treaty

Section 30 provides that the Minister must not surrender an individual if a mandatory restriction on surrender applies under the provisions of a treaty between New Zealand and China. $^{71}$ It is not clear if this provision only applies to bilateral treaties or includes multilateral treaties in force between the countries. An "extradition treaty" or "treaty" is defined by the Act as a treaty or agreement between New Zealand and any country or countries relating to the surrender of individuals accused or convicted of offences. ${ }^{72}$ It appears that this would include both bilateral and multilateral extradition treaties although there is uncertainty concerning the correct interpretation of this definition as the term "multilateral treaty" has a separate definition under the Act. ${ }^{73}$ There is currently no extradition agreement between China and New Zealand.

\section{(b) Torture}

Section 30 creates a mandatory restriction against surrender where it appears to the Minister that there are substantial grounds for believing that an individual would be in danger of being subject to an act of torture in China. ${ }^{74}$ This is in keeping with New Zealand's international obligations as a party to the Convention against Torture and Other Cruel, Inhuman or Degrading Treatment or Punishment ${ }^{75}$ (CAT) and the International Covenant on Civil and Political Rights (ICCPR). Notably the provision does not include

\footnotetext{
${ }^{69}$ Extradition Act 1999, s 8(2).

${ }^{70}$ Law Commission, above n 10, at 102.

${ }^{71}$ Extradition Act 1999, s 30(2)(ab).

72 Section 2.

${ }^{73}$ Section 60(5).

${ }^{74}$ Section 30(2)(b).

75 United Nations Convention against Torture and Other Cruel, Inhuman or Degrading Treatment or Punishment, 1465 UNTS 85, (opened for signature 10 December 1984, entered into force 26 June 1987) [CAT], art 3(1).
} 
"cruel, inhuman or degrading treatment or punishment"76 falling short of the Convention's definition of torture. ${ }^{77}$

(c) New Zealand citizenship

It is mandatory for the Minister to refuse the surrender of a New Zealand citizen under section 30, if either a bilateral treaty or an Order in Council designating the requesting country to use the standard procedure prohibits New Zealand citizens from being surrendered. ${ }^{78}$ If there is no bilateral treaty or Order in Council providing for such a prohibition, the Minister must not surrender a New Zealand citizen if a specific undertaking or arrangement with the requesting country prohibits the surrender of a citizen. ${ }^{79}$ There is no applicable treaty, Order in Council, or undertaking or arrangement precluding the surrender of New Zealand citizens to China. However, the Minister still has a discretionary ground for refusing to surrender a New Zealand citizen if it would not be in the interests of justice to do so. ${ }^{80}$ This is generally in keeping with the common law tradition of not distinguishing between citizens and non-citizens with respect to extradition. ${ }^{81}$ This approach is very different from most civil law countries where the extradition of citizens is usually prohibited.

\section{(d) Speciality}

Section 30 provides that the Minister must not surrender an individual unless the requesting country's law, a provision in an applicable extradition treaty, or an undertaking is given by the requesting country that the individual will not be detained or tried in that country for an offence committed before surrender other than the offence or offences for which surrender was ordered. ${ }^{82}$ This principle of speciality developed out of a concern that a requesting country might prosecute an individual for a political offence after the individual had been surrendered in relation to a non-political offence. Prosecution for an unrelated offence for which an individual was not surrendered would amount to false pretences and an abuse of process. ${ }^{83}$ It is also mandatory for the Minister to refuse surrender unless the requesting country's law, an applicable treaty or an

\footnotetext{
${ }^{76} \mathrm{ICCPR}$, art 7.

${ }^{77}$ Law Commission, above n 10, at 103-104.

${ }^{78}$ Extradition Act 1999, s 30(2)(c)(i) and (ii).

${ }^{79}$ Section 30(2)(c)(iii).

${ }^{80}$ Section 30(3)(c).

${ }^{81}$ Law Commission, above n 10, at 105.

${ }^{82}$ Extradition Act 1999, s 30(5).

${ }^{83}$ Law Commission, above n 10 , at 108.
} 
undertaking from the requesting country assures that an individual will not be surrendered to a third country for prosecution or punishment in respect of an unrelated offence committed before surrender. ${ }^{84}$

\section{Minister's discretionary grounds for refusal under section 30}

(a) Death penalty

The Minister has a discretionary ground under section 30 to refuse surrender where an individual may be or has been sentenced to death in China. ${ }^{85}$ This ground for refusal is subject to China's ability to sufficiently assure the Minister that an individual will not be sentenced to death or, if a death sentence has already been imposed, that sentence will not be carried out once extradited to China. ${ }^{86}$ The provision of this ground is in line with New Zealand's abolition of the death penalty and its commitment to abolition of the death penalty internationally. ${ }^{87}$

\section{(b) Compelling or extraordinary circumstances}

The Minister has a discretionary ground for refusing surrender where compelling or extraordinary circumstances relating to an individual would make it unjust or oppressive to surrender such an individual. Such circumstances include without limitation the age or health of the individual. ${ }^{88}$ After deciding to extradite an individual, the Minister may also make an order delaying an extradition until after the expiration of a specified period, where such compelling or extraordinary circumstances would make it unjust or oppressive to extradite the individual immediately. ${ }^{89}$

\section{(c) Any other reason}

Finally, section 30 provides for a broad discretionary ground allowing the Minister to determine that an individual is not to be surrendered "for any other reason the Minister considers that the person should not be surrendered". 90 Arguably, this has become the most significant ground when the Minister considers whether to surrender an individual

\footnotetext{
${ }^{84}$ Extradition Act 1999, s 30(5)(e).

${ }^{85}$ Section 30(3)(a).

${ }^{86}$ Section 30(3)(a)(i) and (ii).

${ }^{87}$ Law Commission, above $\mathrm{n} 10$, at 105.

${ }^{88}$ Extradition Act 1999, s 30(3)(d).

${ }^{89}$ Section 32(4).

${ }^{90}$ Section 30(3)(e).
} 
for extradition to China. This ground is engaged when the Minister considers whether there is any reason to have concern regarding an individual's fair trial rights if extradited to China. ${ }^{91}$

C New Zealand's International Obligations

\section{New Zealand's multilateral obligations}

Issues with respect to New Zealand's international legal obligations inevitably arise when extraditing an individual from New Zealand to China. The most notable are New Zealand's obligations under international human rights instruments such as CAT and the ICCPR. This is because the use of torture by China's state law enforcement is still endemic despite moves to outlaw such practices and China's justice system still struggles to meet international standards in terms of its administration of justice despite recent changes to China's laws of criminal procedure. ${ }^{92}$ Accordingly, New Zealand's international human rights obligations work to disincline the Minister to surrender an individual for extradition to China. However, New Zealand has other international obligations which directly oblige the Minister to surrender an individual for extradition in respect of certain kinds of serious offending, such as terrorism, human trafficking, drug trafficking and corruption. For example, as China and New Zealand are both state parties to the United Nations Convention against Corruption (UNCAC), there is an obligation on New Zealand to extradite an individual to China where the extradition offence for which the individual is sought is corruption as defined under UNCAC.

2 Convention against Torture and Other Cruel, Inhuman or Degrading Treatment or Punishment

Article 3 of CAT provides:

No State Party shall expel, return (refouler) or extradite a person to another State where there are substantial grounds for believing that he would be in danger of being subjected to torture.

\footnotetext{
${ }^{91}$ Kyung Yup Kim v Minister of Justice [2016] NZHC 1490, [2016] 3 NZLR 425 at [85] [first judicial review]; and Kyung Yup Kim v Minister of Justice [2017] NZHC 2109, [2017] 3 NZLR 823 at [68] [second judicial review].

${ }_{92}$ Ira Belkin "China's Tortuous Path Towards Ending Torture in Criminal Investigations" (2010-2011) 24 Colum J Asian L 273.
} 
Notably, this international prohibition on extradition where there is a risk of torture only applies to cases involving torture and does not include cases involving other cruel, inhuman or degrading treatment that would not amount to torture as defined by the Convention. ${ }^{93}$

\section{International Covenant on Civil and Political Rights}

\section{Article 7 of the ICCPR provides:}

No one shall be subjected to torture or to cruel, inhuman or degrading treatment or punishment.

Article 14 of the Covenant provides for the following relevant minimum standards of criminal procedure and administration of justice:

1. All persons shall be equal before the courts and tribunals. In the determination of any criminal charge against him... everyone shall be entitled to a fair and public hearing by a competent, independent and impartial tribunal established by law....

2. Everyone charged with a criminal offence shall have the right to be presumed innocent until proved guilty according to law.

3. In the determination of any criminal charge against him, everyone shall be entitled to the following minimum guarantees, in full equality:

(a) To be informed promptly and in detail in a language which he understands of the nature and cause of the charge against him;

(b) To have adequate time and facilities for the preparation of his defence and to communicate with counsel of his own choosing;

(c) To be tried without undue delay;

(d) To be tried in his presence, and to defend himself in person or through legal assistance of his own choosing; to be informed, if he does not have legal assistance, of this right; and to have legal assistance assigned to him, in any case where the interests of justice so require, and without payment by him in any such case if he does not have sufficient means to pay for it;

${ }^{93}$ Law Commission, above n 10, at 103. 
(e) To examine, or have examined, the witnesses against him and to obtain the attendance and examination of witnesses on his behalf under the same conditions as witnesses against him;

(f) To have the free assistance of an interpreter if he cannot understand or speak the language used in court;

(g) Not to be compelled to testify against himself or to confess guilt.

...

7. No one shall be liable to be tried or punished again for an offence for which he has already been finally convicted or acquitted in accordance with the law and penal procedure of each country.

In the context of a Ministerial decision on whether to extradite an individual from New Zealand to China, New Zealand's international obligations mean that the Minister must assess "whether there is a real risk of a departure from the standard [under article 14] such as to deprive the defendant of a key benefit of the right in question". ${ }^{94}$ The trial need not comply with article 14 in the same way a trial would be conducted in New Zealand. There is some room for differences in approach between countries' legal systems provided the individual receives the key benefits of the rights outlined in article $14 .{ }^{95}$

\section{United Nations Convention against Corruption}

UNCAC is a multilateral agreement aimed at combating corruption through prevention, criminalisation, international cooperation and asset recovery. UNCAC obliges state parties to establish domestic criminal offences relating to corruption as outlined in the Convention. Broadly these offences include bribery, embezzlement, abuse of public functions, money laundering and obstruction of justice. ${ }^{96}$ While UNCAC predominately deals with mutual assistance in criminal and civil matters, the international cooperation component of the Convention deals specifically with extradition. In fact the Convention can be used as a legal basis for extradition between state parties to the Convention in the absence of a bilateral treaty between the parties when extradition is sought to prosecute offences relating to corruption as established by the Convention.

\footnotetext{
${ }^{94}$ Kyung Yup Kim v Minister of Justice [2019] NZCA 209 at [179].

${ }^{95}$ At [179].

${ }^{96}$ United Nations Convention against Corruption 2349 UNTS 41 (opened for signature 9 December 2003, entered into force 14 December 2005) [UNCAC], arts 15 to 25.
} 
UNCAC places an obligation on state parties to extradite individuals facing prosecution or punishment for corruption offences established in accordance with the Convention to other state parties to the Convention. ${ }^{97}$ However, there is no obligation to extradite an individual where a state party has substantial grounds for believing that a request from another state party has been made for the purpose of prosecuting or punishing an individual for a discriminatory reason, such as, an individual's sex, race, religion, nationality, ethnic origin or political opinions, or would prejudice an individual's position for one or more of these discriminatory reasons. ${ }^{98}$ State parties to UNCAC are obliged to seek to conclude bilateral and multilateral agreements and arrangements to facilitate and enhance the effectiveness of extradition ${ }^{99}$ and mutual legal assistance ${ }^{100}$ under the Convention. There is also an obligation on state parties to consider transferring proceedings for prosecution of offences established by UNCAC where such a transfer is considered to be in the interests of the proper administration of justice, particularly where several jurisdictions are involved. ${ }^{101}$ A state party may take all necessary measures to establish jurisdiction over UNCAC offences when an alleged offender is in its territory and the party does not extradite him or her. ${ }^{102}$

UNCAC entered into force on 14 December 2005. New Zealand and China both signed the Convention as early as 10 December 2003, but New Zealand did not ratify it until 1 December 2015. China ratified the Convention on 13 January 2006 but made the reservation that it does not consider itself bound by the Convention's dispute resolution process. ${ }^{103}$ This process recognises the jurisdiction of the International Court of Justice (ICJ) to adjudicate disputes as to the interpretation and application of the Convention when arbitration is requested by a state party to resolve a dispute and the state parties to the dispute are unable to agree on the organisation of the arbitration. ${ }^{104}$ At the time of writing this thesis, UNCAC had never been used as the basis of an extradition request to New Zealand.

\footnotetext{
${ }^{97}$ Article 43(1).

${ }^{98}$ Article 44(15).

${ }^{99}$ Article 44(18).

${ }^{100}$ Article 46(30).

${ }^{101}$ Article 47.

${ }^{102}$ Article 42(4).

${ }^{103}$ Article 66(3).

${ }^{104}$ Article 66(2).
} 


\section{Other multilateral agreements involving extradition}

In 2014, the Law Commission estimated that there were at least 25 multilateral treaties containing extradition obligations. ${ }^{105}$ These treaties have come into existence from the 1970s onwards and deal with serious crimes such as hostage taking, genocide, drug trafficking and terrorism. Some of these treaties, to which both New Zealand and China are state parties, also place an obligation on both countries to extradite for particular kinds of offending. Most of these treaties include an obligation to "extradite or prosecute". ${ }^{106}$ For example, both China and New Zealand have signed and ratified the Convention against Transnational Organised Crime (UNTOC). The Convention applies specifically to forms of transnational crime, such as participating in an organised criminal group, money laundering, corruption and obstruction of justice. There are also two Protocols specifically dealing with human trafficking. New Zealand has signed and ratified both Protocols. China has only ratified the first. The provisions of the Convention relating to extradition are almost identical to those under UNCAC, although the language of UNTOC does not explicitly place an onus on member states to cooperate in extradition in the same way that UNCAC does. ${ }^{107}$

In the next chapter, this thesis will consider a specific case study involving the extradition of Kyung Yup Kim, the first and only extradition request by China to New Zealand at the time of writing this thesis. This will allow an analysis of how New Zealand's domestic law and international law are applied to an extradition request from China to New Zealand and how the law in this area has developed as the decision to surrender Kyung Yup Kim has been reviewed by the New Zealand courts.

\footnotetext{
${ }^{105}$ Law Commission, above n 10, at 22.

106 At 23.

${ }^{107}$ Compare article 16 of the United Nations Convention against Transnational Organised Crime 2225 UNTS 209 (opened for signature 15 November 2000, entered into force 29 September 2003) [UNTOC] and UNCAC, art 43(1).
} 


\section{Case Study: Kyung Yup Kim}

This chapter undertakes a case study of the extradition of Kyung Yup Kim a Korean citizen and New Zealand permanent resident accused of murdering a woman in Shanghai in 2009. This is the first and only time China has requested the extradition of an individual from New Zealand. This case demonstrates the international human rights issues that arise when extraditing an individual from New Zealand to China and the limitations of the current ad hoc extradition system currently in place between the two countries. It is clear that China hopes to set a precedent by way of Kim's extradition proceedings paving the way for it to seek the extradition of so called "economic fugitives" who are alleged to be residing in New Zealand. However, this has proved a difficult precedent to set. After nearly eight years since the extradition proceedings were commenced, the Court of Appeal quashed the Minister of Justice's decision to surrender Kim in June 2019 remitting Kim's case back to the Minister to reconsider whether to surrender Kim for extradition. The Crown has since applied to the Supreme Court for leave to appeal that decision. There is currently only uncertainty as to whether China can successfully seek extradition of an individual from New Zealand under the current ad hoc system with its reliance on non-binding diplomatic assurances. As will be shown in later chapters, Kim's case demonstrates why a more structured extradition relationship is needed through the implementation of a legally binding extradition treaty between New Zealand and China.

\section{A Procedural Background}

By the time Pei Yun Chen's body was discovered in a wasteland in Qibao town in Shanghai on 31 December 2009, Kim had already left China for South Korea. A warrant for his arrest was not issued in Shanghai until March 2010. ${ }^{108}$ Despite an Interpol alert being issued in May that same year, Kim left Korea and returned to New Zealand in October 2010. New Zealand received a request from China for Kim's extradition in May 2011. The District Court issued a provisional arrest warrant for Kim resulting in his arrest on 10 June $2011 .{ }^{109} \mathrm{Kim}$ was to remain in custody for just over five years until he was eventually granted bail on 21 September 2016 following the first judicial review of the Minister's decision to surrender him for extradition. ${ }^{110}$

\footnotetext{
${ }^{108}$ At [4].

${ }^{109}$ Kyung Yup Kim v Minister of Justice [discharge application], above $\mathrm{n}$ 6, at [38]-[40].

${ }^{110}$ Kyung Yup Kim v Attorney General [bail decision] [2016] NZHC 2235.
} 
The District Court determined that Kim was eligible for surrender on 29 November 2013 and accordingly held that there was a prima facie case against Kim. This decision was initially subject to appeal proceedings, but Kim abandoned the appeal on 12 September 2014. After much consultation with the Chinese authorities regarding adequate assurances for Kim's extradition, the then Minister of Justice, the Hon Amy Adams, finally decided to surrender Kim on 30 November 2015. On 11 December 2015, Kim applied to the High Court for judicial review of the decision to surrender him. ${ }^{111}$ On 1 July 2016 Mallon J granted Kim's application for review of the order to surrender him. ${ }^{112}$ The matter was remitted back to the Minister for her to reconsider whether to surrender Kim. On 19 September 2016, after further information had been provided to the Minister, she again decided to surrender Kim to China. Kim once again applied for review of her decision. This time, Mallon J decided that the Minister's decision was a lawful exercise of her discretionary power under the Act and accordingly dismissed Kim's application in August 2017. ${ }^{113}$ This decision was further appealed to the Court of Appeal. On 11 June 2019, the Court of Appeal granted Kim's appeal remitting the case back to the Minister for reconsideration for a second time. ${ }^{114}$

\section{$B$ Relevant Country Information}

In order to understand the human rights issues surrounding Kim's case, it is necessary to consider the evidence before the Minister and the courts relating to human rights issues in China and the Chinese criminal justice system at the time she made her decision. The Minister made her first decision to surrender Kim on the basis of information provided to her in a briefing paper which drew on information regarding China's judicial system from a number of sources, including submissions made on behalf of Kim by his lawyer Dr Tony Ellis. This information covered the widespread use of torture to extract confessions in China, the nature of China's criminal justice system and the likelihood of Kim receiving a fair trial if surrendered, the death penalty and Kim's mental health. The briefing paper also outlined the assurances that China had given with respect to Kim's treatment after surrender and the monitoring arrangements to ensure that China would adhere to its assurances after surrender. ${ }^{115}$

${ }_{111}^{11}$ Kyung Yup Kim v Minister of Justice [discharge application], above $\mathrm{n}$ 6, at [40]-[51].

${ }^{112}$ Kyung Yup Kim v Minister of Justice [first judicial review], above n 91.

${ }^{113}$ Kyung Yup Kim v Minister of Justice [second judicial review], above n 91.

${ }^{114}$ Kyung Yup Kim v Minister of Justice, above $\mathrm{n} 94$.

${ }^{115}$ Kyung Yup Kim v Minister of Justice [second judicial review], above n 91, at [11]. The briefing papers are not available to the public. The author made a request to the Ministry of Justice for this information under the Official Information Act 1982 [OIA]. The author's request for the Minister's briefing papers was declined under the OIA by the Ministry of Justice via letter dated 17 August 2018, because release of the 
At the first judicial review hearing, Kim adduced expert evidence from Clive Ansley, an expert on China's judicial system. Mallon J allowed Kim to adduce this evidence on the basis that it was relevant to whether the Minister had sufficient evidence before her when she made her decision. ${ }^{116}$ When the Minister decided to surrender Kim for a second time, she was provided with further updated information and advice from Professor Fu Hualing, a Professor of Law at the University of Hong Kong. ${ }^{117}$ What follows will briefly outline the relevant aspects of the evidence before the Minister by borrowing from the country information provided to the Minister in the briefing papers, but also by drawing on other academic writing relating to the use of torture in China and the Chinese criminal justice system.

(a) Endemic torture

Heavy reliance on confessions by Chinese law enforcement agencies has a long history dating back to imperial times. ${ }^{118}$ China's criminal procedure law exacerbates the risk of police obtaining a forced confession by allowing the police to hold a criminal suspect after arrest for up to 37 days before a suspect is charged. ${ }^{119}$ International sources point to a persistent and prevalent use of torture to extract confessions from suspects by Chinese law enforcement agencies. ${ }^{120}$ There have also been some widely reported cases of wrongful conviction as a result of coerced confessions being extracted by the police ${ }^{121}$, which has led the Chinese National People's Congress to make a series of changes to the Criminal Procedure Law of the People's Republic of China (CPL) addressing these issues. The most significant changes were adopted in 2012. For example, it is mandatory for investigators to record or videotape an interrogation throughout the interrogation

information would be likely to prejudice the maintenance of the law and withholding of the information is necessary to maintain legal professional privilege.

${ }^{116}$ Kyung Yup Kim v Minister of Justice [first judicial review], above n 91, at [14].

${ }^{117}$ Kyung Yup Kim v Minister of Justice [second judicial review], above n 91, at [49].

${ }^{118}$ Belkin, above n 92, at 278.

${ }^{119}$ Criminal Procedure Law of the People's Republic of China 2012 [CPL], art $89<$ www.cecc.gov>. See Ira Belkin "China's Criminal Justice System: A Work in Progress" (2000) 6(2) Washington Journal of Modern China 61.

${ }^{120}$ Manfred Nowak Civil and Political Rights, Including the Question of Torture and Detention: Report of the Special Rapporteur on torture and other cruel, inhuman or degrading treatment or punishment: Mission to China E/CN4/2006/6/Add6 (2006); Manfred Nowak Report of the Special Rapporteur on torture and other cruel, inhuman or degrading treatment or punishment: Follow-up to the recommendations made by the Special Rapporteur A/HRC/13/39/Add6 (2010) [Manfred Nowak 2010 report]; and Human Rights Watch "Tiger Chairs and Cell Bosses: Police Torture of Criminal Suspects in China” (13 May 2015) Human Rights Watch <www.hrw.org>.

${ }^{121}$ Belkin, above n 92, at 274. 
process where the suspect is accused of a crime punishable by life imprisonment or capital punishment; or the accused is implicated in a major criminal case. ${ }^{122}$ Most notable is the inclusion of an exclusionary rule in respect of evidence obtained by way of torture applicable to any criminal case, not just capital punishment cases. ${ }^{123}$

China ratified CAT on 4 October 1988. However, it made reservations declining to recognise the competence of the Committee against Torture to investigate and report under article 20; and rejected the dispute resolution mechanism and jurisdiction of the ICJ under article 30. China has not made a declaration under article 22 that it recognises the Committee's jurisdiction to receive and consider complaints of torture from individuals within China. China has not signed or ratified the Optional Protocol which provides for a system of regular visits by independent international and national bodies to investigate allegations of torture.

\section{(b) Criminal trials in China}

This section will outline the various aspects of China's criminal justice system relevant to the human rights issues that arose when the New Zealand courts considered the Minister's decision to surrender Kim for extradition.

(i) Ratification of the International Covenant on Civil and Political Rights

China signed the ICCPR on 5 October 1998, but has not ratified the Covenant nor signed or ratified the First Optional Protocol ${ }^{124}$ to the ICCPR, which provides for the Human Rights Committee to receive and consider complaints from individuals relating to alleged violations of the ICCPR. China has not signed and ratified the Second Optional Protocol $^{125}$, which concerns the abolition of the death penalty.

(ii) Judicial independence

There is no separation of powers in China. The Communist Party usually intervenes in court cases via the political-legal committee. However, the party may also influence cases

\footnotetext{
122 CPL, art 121.

${ }^{123}$ Article 54.

${ }^{124}$ Optional Protocol to the International Covenant on Civil and Political Rights 999 UNTS 302 (opened for signature 16 December 1966, entered into force 23 March 1976).

${ }^{125}$ Second Optional Protocol to the International Covenant on Civil and Political Rights 999 UNTS 414 (opened for signature 15 December 1989, entered into force 11 July 1991).
} 
through the party committee, judicial committee ${ }^{126}$ or the president of the court despite party involvement in specific cases not being permitted by law. The National People's Congress is the highest organ of state power and has the right to supervise the judiciary. This supervisory role can result in direct intervention in specific cases, although this is rare. Under the Chinese Constitution, the procuracy has the right to supervise the courts. ${ }^{127}$ Although this power imbalance is very real and significantly diminishes any actual independence of the courts in China, political interference in regular run of the mill criminal cases is thought to be marginal. Political interference in criminal cases is greatest in high profile cases such as corruption cases involving party members or government officials, which are generally decided by the party disciplinary committee before being turned over to the courts for formal ratification. ${ }^{128}$ However, a lack of data due to a general lack of transparency makes the inner workings of the Chinese court system at best murky, creating real difficulty in ascertaining how much political influence really takes place.

It appears that the court who hears a case is often not the final determiner of a case. Instead the judicial committee comprising a standing committee of between five to seven "judges", including a Communist Party spokesman, convenes a meeting which is closed to the public and decides the judgments of pending cases. Such decisions are made on the basis of the written evidence that was before the court which heard the case without the committee members having heard any evidence from the witnesses or having attended the hearing of the case. ${ }^{129}$ The CPL stipulates that after a hearing of a complex or major case which a panel of judges considers difficult to determine, the Court shall refer the case to the president of the court for the president to decide whether to submit the case to the judicial committee for discussion and determination. If this takes place, the panel of judges must deliver the decision of the judicial committee. ${ }^{130}$ In addition to this stipulation, the CPL also provides the president of the court with the power to refer a case to the judicial committee if the president finds some definite error in a judgment or order of the court, including an error as to the determination of the facts of a specific case. ${ }^{131}$

\footnotetext{
${ }^{126}$ Also known as the adjudicative or adjudication committee.

${ }^{127}$ Randall Peerenboom "Judicial Independence in China: Common Myths and Unfounded Assumptions" in R Peerenboom (ed) Judicial Independence in China: Lessons for Global Rule of Law Promotion (Cambridge University Press, New York, 2010) 69 at 80-83.

${ }^{128}$ Yulin Fu and Randall Peerenboom "A New Analytical Framework for Understanding and Promoting Judicial Independent in China" in R Peerenboom (ed) Judicial Independence in China: Lessons for Global Rule of Law Promotion (Cambridge University Press, New York, 2010) 95 at 103-104.

${ }^{129}$ Clive Ansley "The Chinese Judicial System: A Fairy Tale of Beijing” the Verdict (British Columbia, March 2007) at 61.

${ }^{130} \mathrm{CPL}$, art 180 .

${ }^{131}$ Article 243.
} 
(iii) Time and facilities to prepare for trial and access to a lawyer

A criminal suspect is only entitled to retain a lawyer after he or she is interrogated for the first time. ${ }^{132}$ There is no right to have a lawyer present during pre-trial interrogations by the police or procuratorate. If a defence lawyer requests a meeting with a suspect or defendant in custody, the detention facility must arrange for the suspect or defendant to meet with the lawyer promptly no longer than 48 hours after receiving the request. ${ }^{133}$ Disclosure of information held by the prosecution to the defendant is discretionary. ${ }^{134}$

(iv) Right to present a defence and be represented by a lawyer

Defendants have the right to present a defence. ${ }^{135}$ Defendants are legally aided in China when they are unable to afford to retain a lawyer privately. Where a defendant may be sentenced to life imprisonment or death, and the defendant has not retained a lawyer privately, one must be appointed to act for the defendant by a legal aid agency. ${ }^{136}$ However, article 306 of the CL makes it an offence for a defence lawyer to induce a witness or accused to change his or her testimony raising questions as to whether a defence lawyer could safely lead evidence from an accused person that is contrary to evidence given at pre-trial interrogations without being prosecuted. ${ }^{137}$ Clive Ansley, in his evidence for the judicial review proceedings, noted that a "disturbingly large number of Chinese defence counsel are now incarcerated as a result of a conviction under Article 306 ". 138

The conviction rate in China is reportedly 98-99 percent. ${ }^{139}$ Apparently, this is due to the prosecutorial authorities withdrawing charges in a large proportion of the cases where a not guilty verdict is likely rather than facing the humiliation of a not guilty verdict. This is because a not guilty verdict is perceived as an error on the part of the prosecuting authorities, which entails adverse consequences for those involved. If at the end of a trial the court is of the view that a not guilty verdict is likely, this is indicated by the judge to the prosecution and the charge or charges are withdrawn at trial rather than a verdict

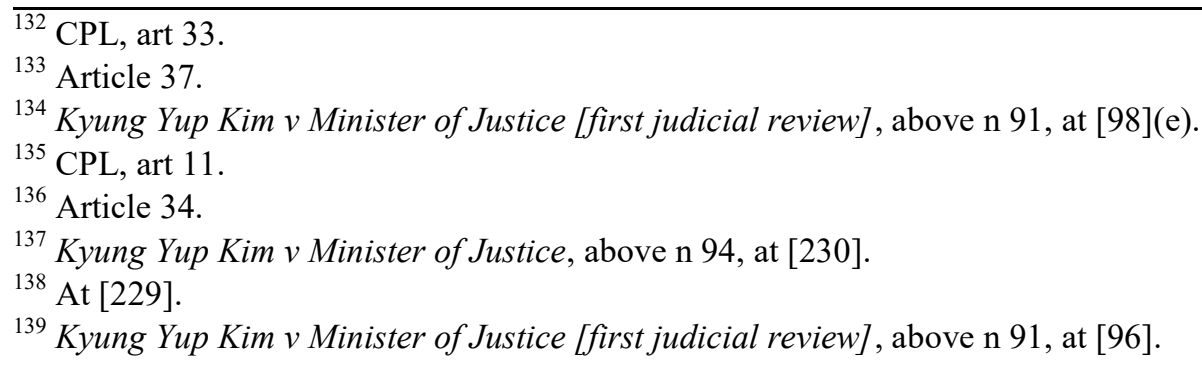


being given by the court. There is no data in respect of the number of these informal withdrawals. ${ }^{140}$

(v) The right to examine witnesses

Witnesses are only required to appear at trial and give evidence if a party to the proceedings objects to the witness' evidence, the evidence of the witness has a material impact on the case, and the court deems it necessary for the witness to appear before the court. ${ }^{141}$ There is no mandatory requirement that witnesses give oral evidence at trial unless the parties to the proceedings agree otherwise. In practice, evidence of witnesses is usually produced at trial by way of formal written statement despite the 2012 reforms placing an obligation on witnesses to testify and be subject to cross-examination. ${ }^{142}$ The Chinese criminal justice system's longstanding reliance on written statements means that there are no related evidentiary protections, such as the hearsay rule, nor is there a procedure for how the prosecution and defence are to examine witnesses at trial. ${ }^{143}$

\section{(vi) Right to silence}

There is no right to silence under Chinese law. ${ }^{144}$ Investigators must first ask a suspect whether or not he or she has committed any criminal act and let the suspect confess or explain his or her innocence before asking further questions. The suspect must answer the investigator's questions truthfully, but has the right to refuse to answer any questions which are irrelevant to the case. Interrogators must also advise the suspect of the provisions $^{145}$ of the CL allowing leniency for those who truthfully confess their crimes. ${ }^{146}$ However, Judges, procuratorial personnel and investigators are strictly prohibited from forcing anyone to provide evidence proving his or her guilt ${ }^{147}$ and there is no criminal liability for refusing to answer questions. ${ }^{148}$ Notwithstanding these provisos to the legal requirements for suspects to answer questions truthfully and to be informed of the law's

\footnotetext{
${ }^{140}$ Kyung Yup Kim v Minister of Justice [second judicial review], above n 91, at [74].

${ }^{141} \mathrm{CPL}$, art 187.

${ }^{142}$ Articles 59, 60, 187 and 188. See David Caruso and Zhuhao Wang "Is an oral-evidence based criminal trial possible in China?" (2017) 21 The International Journal of Evidence and Proof 52 at 55.

${ }^{143}$ Caruso and Wang, above $\mathrm{n} 142$, at 60.

${ }^{144}$ Margaret Lewis "Presuming Innocence, or Corruption, in China” (2012) 50 Colum J Transnat'1 L 287 at 322.

${ }^{145} \mathrm{CL}$, art 67-68.

${ }^{146}$ CPL, art 118.

${ }^{147}$ Article 50.

${ }^{148}$ Kyung Yup Kim v Minister of Justice [first judicial review], above n 91, at [99].
} 
leniency for those who confess, it is clear that Chinese criminal law falls well short of providing an unequivocal right to silence. ${ }^{149}$

(c) Death penalty

Under Chinese law, a number of serious crimes are punishable by death. These include intentional homicide ${ }^{150}$, serious cases of sexual offending ${ }^{151}$, serious corruption (embezzlement or graft) ${ }^{152}$, theft of extraordinarily large amounts of money from financial institutions ${ }^{153}$, serious drug trafficking and manufacture ${ }^{154}$, and some crimes that endanger national security ${ }^{155}$ or public security. ${ }^{156}$ A two-year suspension of execution may be granted at the time the death sentence is imposed. All death sentences must be approved by the SPC and in the case of suspended death sentences by the relevant provincial High People's Court. ${ }^{157}$ If the offender does not intentionally commit a further offence during the two-year suspension period the death sentence may be commuted to a sentence of life imprisonment. ${ }^{158}$ As the suspension period is announced at the same time the death penalty is imposed, it is presumed that the suspension period occurs while the offender is in custody. ${ }^{159}$

\section{High Court Decisions: Kyung Yup Kim v Minister of Justice}

Mallon J's approach to judicial review of the Minister's decisions to surrender Kim was on the basis that a heightened scrutiny was required of the Minister's decision-making due to the surrender decisions involving fundamental human rights and potential risks to Kim's life and liberty. This required the Minister's decision to surrender Kim, on both occasions, to be decisions that would be open to a reasonable decision maker. A successful review of the Minister's decision would require a finding by the Court that her decision was not a decision that would be open to a reasonable decision maker, or more simply that her decision was unreasonable or irrational. A successful review of the Minister's decision would not require the higher threshold of extraordinary

\footnotetext{
${ }^{149}$ Lewis, above n 144 , at 323 .

${ }^{150} \mathrm{CL}$, art 232.

151 Article 236.

152 Article 383.

153 Article 264(1).

154 Article 347.

155 Article 113.

156 Article 115.

157 Article 48.

${ }^{158}$ Article 50.

${ }^{159}$ Article 48.
} 
unreasonableness in the sense that the Court would have to find that no reasonable decision maker could ever have come to the decision made by the Minister. ${ }^{160}$ Therefore, the Court could not supplant the Minister's view with its own view where the Minister's decision was reasonably open to her, even when there may have been other different but equally reasonable decisions open to the Minister on the basis of the information before her: "Different reasonable minds can make different reasonable decisions and proper deference must be given to the decision maker's assessment of matters". ${ }^{161}$ Accordingly, it would be unreasonable for the Minister to make a decision involving a person's fundamental human rights on the basis of inadequate information or without information she ought to have been aware of at the time of making the decision. ${ }^{162}$

\section{Risk of Torture}

The Minister could not order Kim's surrender if there were substantial grounds for believing he would be in danger of being subjected to an act of torture in China. ${ }^{163}$ Mallon $\mathrm{J}$ also concluded that Kim could not be surrendered if there were substantial grounds for believing that he would be subject to cruel, degrading, or disproportionately severe treatment or punishment under the Act's "any other reason" catch-all in section $30(3)(e) .{ }^{164}$ Due to the information before the Minister, confirming the general prevalence of the use of torture in China meant that the Minister could not order Kim's surrender unless satisfied that the assurances given by China removed any risk of him being subject to torture. Mallon $\mathrm{J}$ held that whether the assurances would in fact protect Kim depended on whether China was likely to adhere to the assurances; whether Kim would be able to be actively monitored by New Zealand representatives in China; and whether there were sanctions available in the event that China did not adhere to the assurances. ${ }^{165}$

One of the principal reasons Mallon J referred the Minister's decision to surrender Kim back to the Minister for reconsideration was because the Minster had not explained why she was satisfied the assurances would protect Kim from torture or ill-treatment, particularly in light of the issues as to whether New Zealand could disclose to third parties any breach of the assurances, Kim's lack of access to a lawyer during pre-trial

\footnotetext{
${ }^{160}$ Kyung Yup Kim v Minister of Justice [first judicial review], above n 91, at [7]; and Kyung Yup Kim v Minister of Justice [second judicial review], above n 91, at [18].

${ }^{161}$ Kyung Yup Kim v Minister of Justice [second judicial review], above n 91, at [20].

162 At [17].

${ }^{163}$ Extradition Act 1999, s 30(2)(b).

${ }^{164}$ Kyung Yup Kim v Minister of Justice [second judicial review], above n 91, at [41].

165 At [44].
} 
questioning and an absence of arrangements to ensure proactive monitoring. ${ }^{166}$ The Minister received further advice from the Ministry of Foreign Affairs and Trade (MFAT) regarding whether the assurances allowed New Zealand to disclose breaches of the assurances to third parties. The advice was that if any "serious issue" could not be resolved by way of bilateral consultation, New Zealand would regard the assurances as "broken", relieving New Zealand of any obligation pursuant to the assurances not to disclose a breach to a third party. ${ }^{167}$ She also received further advice that monitoring of the assurances by MFAT staff would be conducted proactively and that the ConsulateGeneral in Shanghai had the capacity, training and experience to undertake such monitoring.

The Minister was also advised by the then Minister of Foreign Affairs, the Hon Murray McCully, that in his opinion the Chinese government was very motivated to comply with the assurances due to their desire to be able to extradite "economic fugitives" from New Zealand. This was because the Chinese government sought to demonstrate to the New Zealand government and the international community that China could be relied on to comply with assurances in such cases. ${ }^{168}$ Echoing Mr McCully's view, Professor Fu also provided advice to the effect that China viewed Kim's case as an opportunity by which to garner credibility in the international community through which it could seek international cooperation and mutual assistance in criminal matters in order to seek extradition of its economic fugitives. ${ }^{169}$

The Hon Murray McCully further assured the Minister that the New Zealand Consulate would be equipped to ensure that Kim would be visited while in detention "every 48 hours or even daily, if that is what is needed". ${ }^{170}$ The Minister advised Mr McCully that in addition to any visits sought by Kim, MFAT should visit at least once every 48 hours during the investigation stage of his detention and no less than every 15 days from then until the end of trial. China also agreed to allow New Zealand representatives access to full and unedited recordings of all pre-trial interrogations within 48 hours of each interrogation taking place. $^{171}$

\footnotetext{
${ }^{166}$ Kyung Yup Kim v Minister of Justice [first judicial review], above n 91, at [259]-[261].

${ }^{167}$ Kyung Yup Kim v Minister of Justice [second judicial review], above n 91, at [50].

${ }^{168}$ At [51]-[52].

${ }^{169}$ At [49](g).

${ }^{170}$ At [53].

${ }^{171}$ At [53]-[55].
} 
Mallon $\mathrm{J}$ held that it was reasonably open to the Minister to conclude that the assurances would be effective in protecting Kim from torture and ill-treatment on the basis of the further information she had received. ${ }^{172}$ The advice to the Minister that the Chinese government was motivated to adhere to the assurances due to its desire to engender cooperation and reciprocity from the international community as a means by which to progress its far reaching anti-corruption campaign appears to have weighed heavily in favour of the Court coming to this conclusion.

\section{Right to a Fair Trial}

In the first judicial review, Mallon $J$ held that the Minister was correct not to apply the "very high standard" or "stringent" test employed by the European Court of Human Rights (ECtHR) requiring a "flagrant denial of justice" in order to warrant declining Kim's surrender. Instead, the Minister adopted a lower threshold whereby she only had to be satisfied that Kim would not receive a trial that reasonably accords with article 14 of the ICCPR in order to decline to surrender Kim. ${ }^{173}$ In terms of the independence of the judiciary in China, the Court held that the evidence provided by Clive Ansley regarding the influence of the judicial committee on court decision-making was not likely to have led the Minister to reach a different conclusion. ${ }^{174}$ Whether the Minister was able to conclude that Kim would receive a trial before an independent and impartial tribunal depended on the Minister's ability to rely on the assurances. ${ }^{175}$ With respect to potential interference by the judicial committee, Mallon $J$ was of the view that whatever the input provided by the committee behind the scenes, a public judgment would result in any case, because the court that hears the trial makes a recommendation to the committee. ${ }^{176}$

Mallon J directed the Minister to reconsider Kim's surrender principally because the Minister had not adequately explained why the assurances could be relied upon when the assurances do not permit New Zealand to disclose information regarding Kim's treatment to third parties. ${ }^{177}$ Secondly, the Minister had not addressed whether the assurances sufficiently protected Kim from ill-treatment and his right to silence during pre-trial interviews when there was no provision in the assurances for Kim to have a lawyer present during pre-trial interrogations and there are conflicting provisions in Chinese law

\footnotetext{
${ }^{172}$ At [67].

${ }^{173}$ Kyung Yup Kim v Minister of Justice [first judicial review], above n 91, at [105]-[112].

${ }^{174}$ At [125].

${ }^{175}$ At [120]-[122].

${ }^{176}$ At [124].

${ }^{177}$ At [259].
} 
as to Kim's compellability to answer questions when interrogated. ${ }^{178}$ Finally, Mallon J commented that the Minister would need to be satisfied that monitoring of Kim would be undertaken proactively and that there was insufficient information before the Minister as to how monitoring would in fact be undertaken. ${ }^{179}$ In terms of the conflicting provisions in Chinese law relating to Kim's right to silence during pre-trial questioning, Mallon J commented that although this issue had been the subject of clarification with Chinese officials, Kim's right to silence had not been specifically addressed in the assurances. ${ }^{180}$

In the second review decision, Mallon $\mathrm{J}$ noted that article 14 of the ICCPR does not require a lawyer to be present during pre-trial questioning, only that a person be able to communicate with a lawyer of his or her own choice and be represented by a lawyer at trial. ${ }^{181}$ Mallon J considered that it would have been preferable for the assurances to have provided Kim with the right to the presence of a lawyer during all interrogations in the same way he would have if questioned in New Zealand, but concluded that the issue was not what assurances could have been sought, but whether the existing assurances protected Kim's fair trial rights. ${ }^{182}$ Although not explicitly stated by Mallon J, Professor Fu's legal opinion appears to have abated the Court's earlier concern regarding the conflicting provisions of Chinese law relating a defendant's right to silence, namely that it is not a crime to refuse to answer questions and prohibition of forced confessions under Chinese criminal law. ${ }^{183}$ On the basis of the assurances and proactive monitoring of the assurances, including China's agreement to provide full and unedited recordings of Kim's interrogations within 48 hours of each interrogation and to allowing New Zealand officials access to Kim every 48 hours, Mallon J concluded that the Minister could be satisfied that Kim's fair trial rights would be adequately protected. ${ }^{184}$

Another issue relating to Kim's ability to cross-examine witnesses at trial was addressed more fully by Mallon $\mathrm{J}$ in the second judicial review decision. Once again, Professor Fu's advice addressing a defendant's ability under Chinese law to require witnesses to be called to give evidence at trial, together with reassurances as to the Minister's ability to rely on the assurance from China that the trial would comply with its domestic law, led

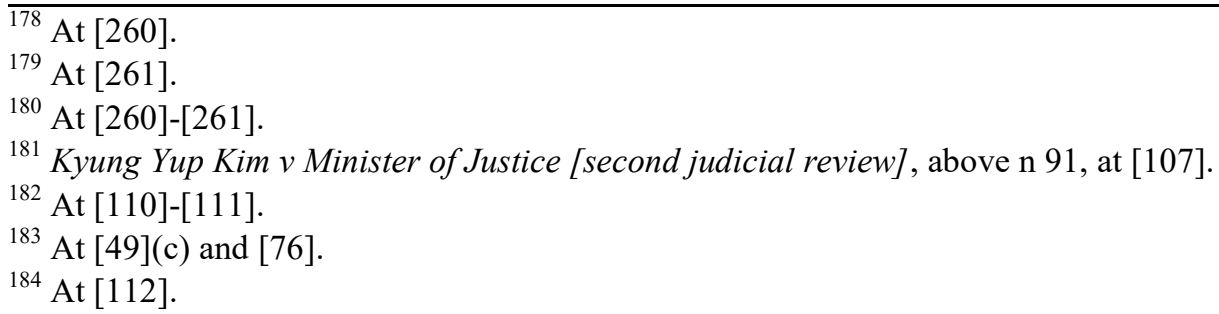


Mallon $\mathrm{J}$ to conclude that it was reasonably open to the Minister to conclude that Kim would receive a fair trial in this respect as well. ${ }^{185}$

\section{Death Penalty}

The request for Kyung Yup Kim's extradition included a decision from the SPC stating that, in accordance with article 50 of the Extradition Law of the People's Republic of China (EL), the trial court would not impose the death penalty, including the death penalty with a two-year suspension, in the event that Kim were found guilty of intentional homicide at trial. ${ }^{186}$ Accordingly, Mallon J held that this ground for refusing to surrender Kim would not prohibit the Minister from ordering Kim's surrender as long as China would adhere to this assurance. Relevant to this issue was whether New Zealand was permitted to disclose a breach of the assurances to third parties and whether the assurances would be proactively monitored. The Minister was directed to reconsider ordering Kim's surrender as she had not addressed these issues in her first decision to surrender Kim. ${ }^{187}$ Furthermore, the information obtained from other countries as to their experience with China honouring similar assurances was limited. This was relevant to the weight that the Minister could place on such information when deciding whether she could be satisfied that China would comply with its assurances. ${ }^{188}$

In the second judicial review decision, Mallon $\mathrm{J}$ held that it was open to the Minister to refuse to surrender anyone to China while it retains the death penalty in line with New Zealand's strong commitment to abolition of the death penalty. However, it was also reasonably open to the Minister to act in accordance with the public interest in prosecuting serious criminal offending when an assurance not to impose the death penalty had been provided by the requesting state and the Minister could rely on that assurance to be honoured. ${ }^{189}$ Notably the Minister could rely on New Zealand's first-hand experience of China honouring an assurance not to impose the death penalty. ${ }^{190}$ Furthermore, the Minister could also rely on China's adherence to the death penalty assurance because

\footnotetext{
${ }^{185}$ At [99]-[101].

${ }^{186}$ Kyung Yup Kim v Minister of Justice [first judicial review], above n 91, at [185].

${ }^{187}$ Kyung Yup Kim v Minister of Justice [second judicial review], above n 91, at [114].

${ }^{188}$ Kyung Yup Kim v Minister of Justice [first judicial review], above n 91, at [241].

189 At [122].

${ }^{190}$ At [234]. Zhen Xiao, a Chinese citizen, was tried and convicted in Shanghai in 2011 for a murder he was alleged to have committed in Auckland before fleeing to China where he was later apprehended by the Chinese authorities.
} 
non-compliance with this particular assurance would unquestionably be very damaging to New Zealand and China's bilateral relationship and China's international reputation. ${ }^{191}$

\section{Court of Appeal Decision: Kyung Yup Kim v Minister of Justice}

Kim's appeal to the Court of Appeal was heard on 17 July 2018. The Court allowed his appeal on a number of grounds in a reserved decision given by Winkelman CJ on a panel that included Cooper and Williams JJ on 11 June 2019. ${ }^{192}$ The Court found that Mallon J did not err in finding that it was open to the Minister to seek diplomatic assurances to meet the risk of torture ${ }^{193}$, or by rejecting the argument that the Minister took into account an irrelevant consideration, namely China's desire to establish credibility in the international community, as being relevant to whether China would honour such assurances. ${ }^{194}$ The Court also found that Mallon J did not err in upholding the Minister's decision that she could rely on China's assurance that Kim would not be sentenced to death. ${ }^{195}$ However, the Court found that the Minister had not addressed the preliminary question as to whether the general human rights situation in China was such that diplomatic assurances could not be relied on. ${ }^{196}$

\section{Torture}

(a) Member of a high risk group

The Court found that the Minister did not take into account an irrelevant consideration by considering whether Kim was a member of a group at a high risk of being subject to torture in China. ${ }^{197}$ However, the Court found that the Minister did not address the issue of whether or not murder accused are at a high risk of torture on the basis of the information before her, nor whether Kim's claim that senior Communist Party members' had an interest in convicting him could take his case outside the ambit of ordinary cases making his risk of torture high. This was because Professor Fu had not addressed this issue in his advice to the Minister. ${ }^{198}$ The Court also found that there was no evidence

\footnotetext{
${ }^{191}$ Kyung Yup Kim v Minister of Justice [second judicial review], above n 91, at [125].

${ }^{192}$ Kyung Yup Kim v Minister of Justice, above $\mathrm{n} 94$.

${ }^{193}$ At [257](a).

${ }^{194}$ At [81]-[83].

${ }^{195}$ At [257](g).

${ }^{196}$ At [77]-[79].

${ }^{197}$ At [117].

${ }^{198}$ At [119]-[120].
} 
before the Minister to establish the view that Kim would be at less risk of torture because the trial would be held in Shanghai. ${ }^{199}$

(b) Adequacy of diplomatic assurances

The Court found that the assurances relating to monitoring Kim while in detention and video-taping of interrogations were not adequate protection against torture. This was because torture is conducted outside the law in China and those that perpetrate torture take steps to make sure that the use of torture is not detected as not all forms of torture leave visible marks. The assurances did not allow consular visits without notice and requiring visits to be scheduled made evidence of torture easier to conceal. ${ }^{200}$ Recording of interrogations did not address the risk of torture occurring when the cameras were turned off. ${ }^{201}$ The assurances relied on Kim, and those associated with his incarceration, reporting torture when there would be disincentives to complain, particularly when Kim would remain under the control of those who had perpetrated the torture. ${ }^{202}$ Furthermore, the information before the Minister indicated that there were unlikely to be consequences for those who perpetrate torture, while co-workers were unlikely to report torture in circumstances where they would probably have to continue to work with the perpetrators. ${ }^{203}$ The evidence also indicated that lawyers in China are not free to represent their clients without fear of retribution and the assurances did not provide for a lawyer to be present during interrogations. ${ }^{204}$ Finally, Professor Fu's evidence was that the Chinese courts had not been able to apply the exclusionary rule against admission of evidence obtained by way of torture effectively. ${ }^{205}$ Accordingly, when considering the evidence before the Minister, the Court concluded that the Minister erred by failing to address how the assurances could protect Kim against torture. ${ }^{206}$

\section{Right to a fair trial}

The Court found that the Minister erred in applying the "reasonable extent standard" when assessing if there was a risk that Kim would not receive a fair trial in China. The Court had reservations regarding the language used to elucidate the concept of a "flagrant

\footnotetext{
${ }^{199}$ At [124]-[126].

${ }^{200}$ At [133].

${ }^{201}$ At [134].

${ }^{202}$ At [135].

${ }^{203}$ At [135].

${ }^{204}$ At [136].

${ }^{205}$ At [137].

${ }^{206}$ At [138]-[139].
} 
denial of justice" developed under the European Convention on Human Rights (ECHR) in Othman (Abu Qatada) v United Kingdom. ${ }^{207}$ The Court thought that the use of the word "flagrant" had a tendency to confuse because it denoted a "high-handed, brazen or scandalous conduct". ${ }^{208}$ The Court had reservations regarding the explanation of the "flagrant denial of justice" test offered by the ECtHR in Othman, that the test requires a departure from the standards of justice so as to "amount to a nullification, or destruction of the very essence, of the right guaranteed by" ${ }^{209}$ article 14 of the ICCPR. The Court had reservations regarding this interpretation of the test because "the language of nullification or destruction expresses the matter in such absolute terms that it errs on the side of setting the threshold too high". 210

The Court considered that the "appropriate threshold is whether there is a real risk of a departure from the standard such as to deprive the defendant of a key benefit of the right in question". ${ }^{211}$ In expressing the test in this way, the Court of Appeal has arguably lowered the threshold for finding a real risk of a flagrant denial of justice well below the "flagrant denial of justice" test and the "reasonable accordance" test applied by the Minister. This new inflection to the test arguably only allows minimal deviation from a relevant fair trial right as a requesting state must dispel almost any doubt regarding the risk of an unfair trial. This risk need only be real and not merely fanciful. The threshold for showing that such a risk in fact exists is "something less than a 51 per cent probability", 212

(a) The right to be tried by an independent tribunal

The Court of Appeal found that it was not reasonably open to the Minister to conclude that the assurances satisfactorily addressed the lack of independence of the Chinese judiciary without further inquiry. ${ }^{213}$ The Court did not think it reasonable to disregard Clive Ansley's evidence regarding the role of the judicial committee in China's criminal justice system, particularly when this evidence was consistent with materials provided to the Minister in her own briefing materials. ${ }^{214}$ The Court found that the evidence before the Minister indicated that political influence and the role of the judicial committee are

\footnotetext{
${ }^{207}$ Othman (Abu Qatada) v United Kingdom (8139/09) Section IV, ECHR 17 January 2012.

${ }^{208}$ Kyung Yup Kim v Minister of Justice, above n 91, at [178].

${ }^{209}$ Othman (Abu Qatada) v United Kingdom, above n 207, at [260].

${ }^{210}$ Kyung Yup Kim v Minister of Justice, above n 91, at [179].

${ }^{211}$ At [179].

${ }^{212}$ At $[180]$.

${ }^{213}$ At [211].

${ }^{214}$ At [212]-[214].
} 
systemic prioritising "social policy objectives over individual procedural protections". ${ }^{215}$ The Court had no doubt that a trial before a tribunal subject to direct political influence would amount to a departure from the ICCPR standard. ${ }^{216}$

The assurances did not address the issue of judicial independence directly. The only relevant assurance was that China would try the case in accordance to domestic law, but that did not meet the concern because political influence on the judiciary is systemic to China's criminal justice system enabling decisions to be made "by a body other than the body that heard the case". ${ }^{217}$ The assurance to comply with international law was insufficient because China has not ratified the ICCPR, meaning that the assurances do not oblige China to comply with the ICCPR. ${ }^{218}$ This is because China has no "applicable international legal obligations" $" 219$ under international law. However, the Court could not exclude the possibility that further information may come to light allowing the Minister to form a different view with respect to judicial independence in China, namely information regarding the extent of the judicial committee's ability to influence decisionmaking in criminal trials. ${ }^{220}$

\section{(b) Right to legal representation}

The Court grouped together the right to present a defence, receive legal assistance, adequate time and facilities to prepare a defence and to examine witnesses.

\section{(i) The right to present and prepare a defence}

The Court held that the Minister had not adequately addressed the issue regarding Kim's access to the evidence against him, noting that on the evidence before the Minister, the police, prosecution and judges had access to this evidence well in advance of the trial, but there is no mandatory requirement that the defence be provided with access to the evidence under Chinese law. The defence can apply for disclosure of evidence held by the prosecution helpful to a defendant's case, but this right is difficult to exercise when the defence does not know what evidence the prosecution has and the grant of such an

\footnotetext{
215 At [217].

${ }^{216}$ At [218].

217 At [219].

${ }^{218}$ At [219]-[220].

219 At [220].

${ }^{220}$ At $[221]$.
} 
application is discretionary. The Court held that the Minister should have sought assurances regarding the timing and content of the evidence held by the prosecution. ${ }^{221}$

(ii) Right to adequate legal assistance

The Court was troubled by the evidence relating to the treatment of the defence bar in China, namely the prosecution and imprisonment of defence lawyers involved in human rights cases. The Court thought that further enquiry was required with regard to the offence under article 306 of the CL for defence lawyers to induce witnesses or an accused to change their evidence and whether this in fact has a chilling effect on a defence lawyer's ability to effectively represent an accused person. The Court had no doubt that if defence lawyers in China were in fear of prosecution for providing representation to their clients, this would amount to deprivation of an accused's right to adequate legal representation. ${ }^{222}$ The Court thought that assurances could not "....address the jeopardy all counsel face by virtue of the provisions of art 306, and in particular the culture of fear that creates". 223

\section{(iii) The right to examine witnesses}

The Court also took issue with the lack of a requirement that witnesses be present to give evidence at trial in China. The right to have witnesses attend trial for questioning depends on the granting of an application which is open to the discretion of a judge. The Court noted its expectation that consideration be given as to whether a specific assurance could be given to ensure that witnesses will attend the trial for cross-examination. ${ }^{224}$

\section{(c) Right to silence}

The Court was of the view that even if interrogations were adequately monitored, this monitoring would not meet the concern that Kim would be questioned without a defence lawyer present. Although there would be no legal consequences as a result of Kim refusing to answer questions this would likely be lost sight of during the course of interrogations, which would likely extend on and off over a period of months pre-trial. Given the obligation that Kim answer questions relevant to the inquiry under article 118 of the CPL, the Court was of the view that access to a lawyer before and after an

\footnotetext{
${ }^{221} \operatorname{At}[238]$.

${ }^{222}$ At [239].

${ }^{223}$ At [240].

${ }^{224}$ At $[242]$.
} 
interrogation was inadequate to ensure Kim's right to silence and that there should be an assurance that Kim has a lawyer present during interrogations. The Court also commented on the issue of who Kim's legal representation should be in light of the "...pressures brought to bear upon the legal profession in the PRC"225, but did not elaborate further by suggesting who might be a suitable legal representative.

\section{Account for time spent in custody pending trial}

The Court held that Kim would be subject to a disproportionately severe punishment in the event time already spent in custody were not taken into account when sentencing him to a finite sentence and that the Minister should have sought an assurance ensuring pretrial detention would be taken into account. The Court was of the view that there was insufficient evidence to determine the issue of whether a sentence of life imprisonment without parole in China would mean that pre-trial detention would effectively not be taken into account, resulting in a disproportionately severe sentence if such a sentence were imposed. ${ }^{226}$

\section{E Diplomatic Assurances}

In terms of judicial review of the Minister of Justice's decision to surrender Kyung Yup Kim for extradition from New Zealand to China, the ECtHR's decision of Othman (Abu Qatada) $v$ United Kingdom ${ }^{227}$ was central to the courts' approach with respect to the Minister's ability to rely on diplomatic assurances in order to maintain New Zealand's international human rights obligations. In Othman (Abu Qatada) v United Kingdom, the ECtHR, for the first time, considered the reliability of assurances negotiated within the framework of a Memorandum of Understanding (MOU) in the assessment of the risk for a deportee, Abu Qatada, upon removal to Jordan. The Court held that deportation with assurances would not be in violation of the prohibition against torture under article 3 of the ECHR, but that the assurances were insufficient with respect to guaranteeing Abu Qatada's right to a fair trial under article 6 of the ECHR. This was because there was a real risk that evidence obtained by means of torture would be admitted into evidence at Abu Qatada's retrial in Jordan.

There are opposing views as to whether diplomatic assurances create legally binding obligations on a state party. In rejecting recent notions of "politically binding

\footnotetext{
${ }^{225}$ At [256].

${ }^{226}$ At [267]-[268].

${ }^{227}$ Othman (Abu Qatada) v United Kingdom, above n 207.
} 
agreements", Klabbers argues that diplomatic assurances should be considered legally binding agreements: ${ }^{228}$

Treaties rest upon the agreements of states. More importantly, as soon as there is some form of agreement, international legal rights and/or obligations are created. In other words: we deny the possibility of there being alternatives to law-making: a commitment is either legal, or it is no commitment at all.

Aust suggests that diplomatic agreements such as MOUs are not always binding on the parties as such arrangements are entered into all the time by states without an intention that they be legally binding. ${ }^{229}$ Such agreements are often preferred by states because they provide confidentiality, flexibility, and are able to be created quickly and amended easily. ${ }^{230}$ Aust argues that while state parties to non-binding instruments may have no intention to be legally bound nevertheless such agreements may give rise to legal consequences in certain circumstances. ${ }^{231}$ Aust argues that the decisive factor by which to determine whether an agreement is legally binding, and in fact a treaty, is whether the parties to the agreement intended the agreement to be binding or not. ${ }^{232}$ This requires an examination of the language used in the agreement and the circumstances in which an agreement was concluded to ascertain whether the parties intended to be legally bound by an agreement. $^{233}$

In the judicial review decisions in the High Court ${ }^{234}$ and Court of Appeal ${ }^{235}$, the focus was on the reputational consequences of a breach of the assurances for China and China's motivation to garner co-operation and goodwill from the international community in order to pursue its anti-corruption campaign internationally. This was because the assurances provided by China to New Zealand were not intended to be binding on the parties. The Court of Appeal noted with reference to the legal advice provided to Minister Adams by MFAT that: ${ }^{236}$

\footnotetext{
228 Jan Klabbers The Concept of Treaty in International Law (Kluwer Law International, The Hague, 1996) at 13. Also see Gregor Noll "Diplomatic Assurances and the Silence of Human Rights Law" (2006) 7 Melb J Intl L 104.

${ }^{229}$ Anthony Aust Modern Treaty Law and Practice (2nd ed, Cambridge University Press, New York, 2007) at 20-21, 49-52.

${ }^{230}$ At $43-46$.

${ }^{231}$ At 53-55.

${ }^{232}$ At 20.

${ }^{233}$ At 33-39.

${ }^{234}$ Kyung Yup Kim v Minister of Justice [first judicial review] and [second judicial review], above n 91.

${ }^{235}$ Kyung Yup Kim v Minister of Justice, above $\mathrm{n} 94$.

${ }^{236}$ At [27].
} 
It is common ground that the diplomatic assurances provided in this case do not impose legally enforceable obligations upon the PRC... They are not, in themselves, binding under international law unless the undertakings are set out in treaties.

Furthermore, it is doubtful that China's assurances to New Zealand could create legal obligations in the form of a unilateral declaration. The ICJ in the Nuclear Tests cases ${ }^{237}$ formulated two criteria for finding that unilateral declarations have legal effect. Firstly, the declaration must be made with an intention to be bound, and secondly, it must be made in public. ${ }^{238}$ It is clear from what has been revealed in the proceedings related to Kim's extradition that China does not intend to be legally bound by the diplomatic assurances it has provided. Furthermore, the assurances were not given in public. ${ }^{239}$ The content of the assurances was only released to the public through publication in the High Court and Court of Appeal decisions. Therefore, China's assurances do not comprise a legally "binding unilateral declaration". 240

Despite China's assurances having no legal force, the Court of Appeal did not rule out the use of diplomatic assurances as a means by which to ensure fair trial rights and protections against torture ${ }^{241}$, but in light of the Court's decision, it seems questionable as to whether reliance on diplomatic assurances alone is sufficient protection to allow New Zealand to lawfully extradite an individual to China. It may be rather telling that in Othman (Abu Qatada) v United Kingdom Abu Qatada only "agreed" to return to Jordan following the ratification of a 'mutual legal assistance agreement' between the United Kingdom and Jordan, which explicitly guarantees a number of fair trial rights for

\footnotetext{
$\overline{237}$ Nuclear Tests (New Zealand v France) [1974] ICJ Rep 457; Nuclear Tests (Australia v France) [1974] ICJ Rep 253.

${ }^{238}$ Nuclear Tests (New Zealand v France), above n 231, at [46]; Nuclear Tests (Australia v France), aboive n 231, at [43]. Also see Klabbers, above n 222, at 196-197.

${ }^{239}$ The author made a request to the Ministry of Foreign Affairs and Trade [MFAT] under the OIA for all relevant aide memoires, notes verbales, exchange of letters and any memorandum of understanding(s) in respect of the assurances sought from China for Kyung Yup Kim's extradition. The author was advised via letter from the Secretary of Foreign Affairs and Trade on 22 March 2018 that the requested information is withheld under the OIA to avoid prejudicing the international relations of the New Zealand government and to protect the passing of information from another government on a confidential basis.

${ }^{240}$ Jack Wong reaches a similar conclusion regarding the legal nature of China's diplomatic assurances. See Jack Wong "Trickled-down Assurances: Could the Central Authority, Treaty, or Judiciary Alleviate Extradition Issues Amongst Non-traditional Treaty Partners?" (LLM Thesis, Victoria University of Wellington, 2018) at 28-29.

${ }^{241}$ Kyung Yup Kim v Minister of Justice, above n 94, at [70].
} 
deportees and prohibits the use of evidence obtained via torture at trial. ${ }^{242}$ Perhaps incidentally Abu Qatada was eventually acquitted at trial after returning to Jordan.

The next chapter examines President Xi Jinping's global anti-corruption campaign, the driving force behind China's desire to extradite individuals who have allegedly fled abroad to escape prosecution for crimes committed in China. This analysis is relevant to the question of whether New Zealand's current ad hoc extradition system with its reliance on non-binding diplomatic assurances is sufficient to withstand a request for a 'high profile' 'economic fugitive' accused of perpetrating corruption in China.

${ }^{242}$ Mariagiulia Giuffre "An Appraisal of Diplomatic Assurances One Year after Othman (Abu Qatada) $v$ United Kingdom (2012)” (2013) 2 Intl Hum Rts L Rev 266 at 268. 


\section{Xi Jinping's Anti-corruption Campaign, Chinese Communist Party Factionalism and Extradition from New Zealand to China}

This chapter examines President Xi Jinping's global anti-corruption campaign, the driving force behind China's desire to extradite individuals who have allegedly fled abroad to escape prosecution for crimes committed in China. As shown in the previous chapter the New Zealand government is faced with relying on non-binding diplomatic assurances to protect individuals sought for extradition by China from torture and to ensure fair trial rights for such individuals after surrender. Even if it is possible for China to one day extradite an individual on the basis of non-binding diplomatic assurances, it remains questionable whether reliance on diplomatic assurances alone would be sufficient to withstand a request for a 'high profile' 'economic fugitive' accused of perpetrating corruption in China. The subsequent analysis of China's anti-corruption campaign will examine this question with particular focus on New Zealand's ability to rely on diplomatic assurances to ensure that China's anti-corruption agency, the CCDI, would not be involved in the prosecution of extradited individuals accused of corruption in China.

\section{A The Underlying Motivation for Xi Jinping's Anti-Corruption Campaign}

The primary motivation behind China's desire to seek bilateral extradition treaties with developed countries is Xi Jinping's far-reaching campaign against corruption, particularly in relation to alleged corruption by Chinese government officials who have fled to other jurisdictions. In order to understand perceived concerns related to the extradition of individuals sought by China to face trial for alleged corruption, it is necessary to understand some of the perceived motivations behind Xi Jinping's anti-corruption campaign and how it differs from previous anti-corruption campaigns the Chinese government has employed in the past. This understanding necessarily entails an analysis of the factional rivalry of the $\mathrm{CCP}$ and how anti-corruption campaigns have been used by different factions to wrest power from rival factions in the past.

Control and consolidation of power over the CCP is dominated by rivalry between different factions made up of complex patronage networks (guanxi). These patronage relationships are often long lasting, uniting different individuals and their families in multigenerational alliances and allegiances. Sometimes, these relationships are formed in line with different ideological blocs within the party, but this is by no means the rule. For example, such networks may have formed in relation to a particular locality, such as the 
"Shanghai clique", or an organisation, like the Communist Youth League. China's anticorruption agency, the CCDI, has recently published the names and whereabouts of 22 of its allegedly most wanted economic fugitives around the world, including four individuals whom are allegedly residing in New Zealand. ${ }^{243}$ Due to China's history of factional rivalry within the $\mathrm{CCP}$, questions arise as to whether there might be political motivations for seeking extradition of these alleged economic fugitives. It has not been uncommon for anti-corruption campaigns to be used as a means by which one faction could oust rivals of an opposing faction, but none have been as long lasting or as far reaching as the current campaign orchestrated under $\mathrm{Xi}$ Jinping. On average, the campaigns of the 1980s and 1990s lasted 28 months. The current campaign started when President Xi took power in November 2012 and has continued into the present. The current campaign is also distinguishable from past campaigns in that it targets both "tigers" (senior high ranking officials) and "flies" (low-ranking bureaucrats) in the government and state-owned enterprises. ${ }^{244}$

What follows will encompass an analysis of the history of party factionalism involving the $\mathrm{Xi}$ family and where the family stands in respect of the major divisions along ideological and personal lines. This is relevant to an assessment of the underlying motivations of Xi Jinping's present day anti-corruption campaign because in many ways the factional rivalries within the CCP in the present have their genesis in the factional and family rivalries of the past. This analysis also demonstrates how anti-corruption campaigns in China are often underpinned by political motivations rather than a genuine desire to address corruption in China.

\section{B Factional Rivalry in the Chinese Communist Party in the Era of President Xi}

At the time that Xi Jinping took power in 2012, there were two main factions vying for control of the CCP. One coalition was led by former President Jiang Zemin's protégés. The core of this coalition used to be known as the "Shanghai gang" or "Shanghai clique", but by the time of Xi's rise, leaders known as "princelings", children from high-ranking families - families of leaders of the revolution - had become more central to this faction. The dominant coalition primarily consisted of former officials from the Chinese Communist Youth League which was led by President Hu Jintao and Premier Wen Jiabao. Jiang Zemin's faction was ideologically aligned to China's "New Left" school of

\footnotetext{
243 "Four of China's 'most wanted' for alleged corruption are reported to be hiding out in Auckland" New Zealand Herald (online ed, Auckland, 28 April 2017).

${ }^{244}$ Peng Wang, The Chinese Mafia: Organized Crime, Corruption, and Extra-Legal Protection (Oxford University Press, Oxford, 2017) at 188.
} 
thought, which advocated hard line Mao-style anti-organised crime "smash the black" campaigns and a state driven development model for China, known as the "Chongqing model". In contrast, the $\mathrm{Hu}-\mathrm{Wen}$ coalition favoured the current market driven development model for Chinese development. ${ }^{245}$

The rivalry between these two factions would culminate in the prosecution and subsequent trial of Bo Xilai, the former party chief of Chongqing and a member of China's Politburo, on corruption charges. To understand the factional dynamics behind Bo Xilai's fall from grace, it is necessary to briefly examine two incidents from the CCP's history and how they involved the Bo and Xi families' factional rivalry. Although both Xi Jinping and Bo Xilai are "princelings" their relationship was greatly affected by their fathers' affiliation to opposing factions. ${ }^{246}$

\section{The Gao Gang affair}

In 1953, a rift had emerged between the newly promoted Gao Gang, who sought a swift transition to socialism, and Mao's deputy in the party, Liu Shaoqi, who favoured a gradual transition. ${ }^{247}$ Bo Yibo (Bo Xilai's father) prepared a draft of the new tax system. Mao was displeased with the moderateness of the draft policy, believing that its drafter held "bourgeois ideas". Mao organised a nationwide party conference on financial and economic work. He intended to expose the "rightists". Gao Gang presided over the conference, launching a vicious attack on Bo Yibo. Everyone took part in criticising Bo Yibo after hearing the main report by Gao Gang. ${ }^{248}$ Bo Yibo was subsequently dismissed as Minister of Finance. ${ }^{249}$

Gao Gang had ambitions to one day succeed Mao. Gao Gang eventually found an ally in Rao Shushi. Despite being warned by Mao not to engage in factional activities, they began making plans on how to divide up posts in their future leadership of the party. After getting wind of the conspiracy, Mao attacked Gao and Rao at a Politburo session. Two commissions were established delivering reports accusing Gao of colluding with the

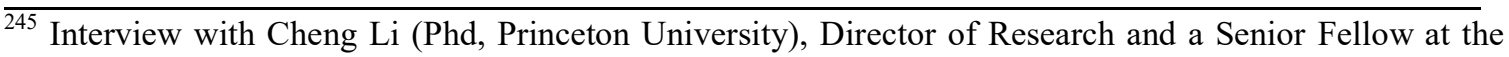
Brookings Institution's John L Thornton China Center (Anton Wishik, The National Bureau of Asian Research, 18 April 2012) <www.nbr.org $>$.

${ }^{246}$ Willy Wo-Lap Lam Chinese Politics in the Era of Xi Jinping: Renaissance, Reform, or Retrogression? (Routledge, New York, 2015) at 13.

${ }^{247}$ Alexander Pantsov and Steven Levine Deng Xiaoping: A Revolutionary Life (Oxford University Press, Oxford, 2015) at 154.

${ }^{248}$ At $156-157$.

${ }^{249}$ At 159 .
} 
Soviets. Several months later, Gao Gang committed suicide. ${ }^{250} \mathrm{Xi}$ Zhongxun (Xi Jinping's father) was an old North Shaanxi comrade of Gao Gang. He was Gao's supporter and reportedly obtained a high-ranking government position through his ties to Gao. ${ }^{251}$ In 1962, Xi proofread and corrected a manuscript which dealt with the events leading to Gao Gang's death. The manuscript was interpreted as an attempt by $\mathrm{Xi}$ Zhongxun at reversing the verdict on Gao Gang. At a party plenum in September 1962, Mao accused Xi of "using a novel to attack the Party". Xi was promptly removed from his posts and reportedly "had a rough time" after his dismissal. ${ }^{252}$

\section{The purging of Hu Yaobang}

$\mathrm{Hu}$ Yaobang was a popular liberal party leader that rose to prominence during the 1980s. Deng Xiaoping made Hu Yaobang general secretary of the Communist Party. By 1986, the increasingly market driven economy and increasingly liberal social environment was on a collision course with the conservative Communist Party elders' desire to maintain absolute political control. Hu Yaobang made attempts to limit the corruption of the party elders' children, ignored conservative ideological campaigns and tolerated the student protests. By January 1987, the conservative party elders succeeded in deposing $\mathrm{Hu}$ Yaobang by way of a "Democratic Party Life Meeting", which consisted of $\mathrm{Hu}$ being subjected to brutal criticism and humiliation by other party leaders over a five day period. Bo Xilai's father, Bo Yibo, chaired the meeting and was by far the harshest of $\mathrm{Hu}$ Yaobang's critics during the five-day meeting. ${ }^{253}$

$\mathrm{Xi}$ Jinping's father, $\mathrm{Xi}$ Zhongxun, and $\mathrm{Hu}$ Yaobang, served together in the party's Northwestern Bureau in 1949. ${ }^{254} \mathrm{Hu}$ Yaobang apparently assisted Xi Jinping's father after his fall from grace in the aftermath of the Gao Gang affair by bringing Xi Zhongxun to a senior leadership position in the Party's Central Secretariat in the early 1980s. Xi Zhongxun was almost the only elder to speak out in Hu's defence at the Party Life Meeting. ${ }^{255}$ Notable Hu Yaobang protégés were former premier Wen Jiabao, who Hu had appointed to run his General Office, and former President Hu Jintao. Hu Yaobang's death in March 1989 precipitated the protests at Tiananmen. Bo Yibo headed the subsequent purge of Hu's liberal successor, Zhao Ziyang, and joined Deng Xiaoping and the elders in

\footnotetext{
${ }^{250}$ At 160-162.

251 Frederick Teiwes Politics at Mao's Court: Gao Gang and Party Factionalism in the Early 1950s (Routledge, London and New York, 2015) at 145.

252 At 140-141.

253 John Garnaut “The Revenge of Wen Jiabao" Foreign Policy (online ed, Washington, 29 March 2012).

${ }^{254}$ Lam, above $\mathrm{n} 246$, at 36.

${ }^{255}$ At 37.
} 
declaring martial law against the protestors. Bo Yibo apparently also moved to purge Wen Jiabao from his position heading the General Office. ${ }^{256}$

During the 1990s, Bo Yibo is reported to have been instrumental in assisting former President Jiang Zemin to power. Bo also apparently assisted Jiang in maintaining power when $\mathrm{Hu}$ Jintao succeeded him as president by staying on as head of the People's Liberation Army. Jiang is rumoured to have repaid this "debt" to Bo Yibo by assisting his son, Bo Xilai, with his political career. ${ }^{257}$

\section{Factionalism and the Prosecution of Bo Xilai for Corruption}

Bo Xilai was affiliated to the faction led by former President Jiang Zemin's protégés. Although the core of this coalition used to be known as the Shanghai Gang, the "princelings" had come to dominate this faction in the lead-up to Xi Jinping being elected by the party as General Secretary and subsequently President. The other coalition primarily consisted of former officials from the Chinese Communist Youth League led by then President $\mathrm{Hu}$ Jintao and premier Wen Jiabao. ${ }^{258}$ Due to Xi Zhongxun's open rebuke at the conservative party elder's dismissal of Hu Yaobang, the Xi family had become alienated by the other princeling clans. ${ }^{259} \mathrm{Xi}$ Jinping had become a member of the Communist Youth League early on in his career and was ideologically aligned to $\mathrm{Hu}$ Jintao and Wen Jiabao's market driven plans for China's economy. ${ }^{260}$

Bo Xilai, on the other hand, was more ideologically conservative. Hu Jintao and Wen Jiabao had apparently assigned Bo to the interior city of Chongqing to reduce his power, but as the party secretary of Chongqing, Bo had managed to put Chongqing on the political map by developing its economy through a state-led development plan that became known as the "Chongqing model". Despite Bo's mother committing suicide during the Cultural Revolution and his father being tortured during this time, Bo often spoke positively of this period of China's history while leader of Chongqing, leading Wen Jiabao to publicly criticise him. ${ }^{261}$

\footnotetext{
${ }^{256}$ John Garnaut The Rise and Fall of the House of Bo: How a Murder Exposed the Cracks in China's Leadership (eBook ed, Penguin, 2012) at ch 3.

${ }^{257}$ Garnaut, above n 256, at ch 3.

${ }^{258}$ Wishik, above n 245.

${ }^{259}$ Lam, above n 246, at 38 .

${ }^{260}$ At 41.

${ }^{261}$ Wishik, above n 245.
} 
When the murder of the English businessman Neil Heywood by Bo Xilai's wife, Gu Kailai, were exposed in late 2011, this revelation provided Bo's rivals with the perfect opportunity to bring about his downfall. Bo had reportedly told people close to him that he was a better choice to lead China than Xi Jinping. As the scandal broke, Hu Jintao, Wen Jiabao, and Xi Jinping combined resources to bring Bo's career to an end. Bo was relieved of all his party positions in March 2012 and ultimately given a life sentence for corruption and abuse of power in September 2013. There was little "democratic" discussion of the scandal within the CCP. Whatever truth there was to the allegations, it was clear that the prosecution of Bo and his wife was politically motivated rather than judicially motivated. ${ }^{262}$ The trial that followed the revelations had many of the hallmarks of a show trial, including lack of transparency in the mainstream media. ${ }^{263}$ In the words of the Beijing historian Zhang Lifan: ${ }^{264}$

[T]he anti-corruption effort is just a political weapon used to take down whoever they want to take down. Because when there is widespread institutional corruption, anti-graft efforts are not going to clean up the system. They are a means to get rid of political opponents.

\section{Anti-corruption Campaign under President Xi Jinping}

True to his promise to target both "tigers" and "flies" with his anti-corruption campaign, the first "tiger" to fall, Zhou Yongkang, was investigated for corruption soon after President Xi's ascendancy to power and Bo Xilai's demise. Zhou was an avid supporter of Bo Xilai. ${ }^{265}$ He had been the Secretary of the Central Political and Legal Affairs Commission between 2007 and 2012, which saw him oversee China's security and law enforcement institutions. He was also a member of the 17th Politburo Standing Committee. When Bo Xilai was detained in March 2012, Zhou and Bo were considered by many to be Xi's political foes. Both reportedly disapproved of the 18th CCP Congress' plan for Xi to succeed Hu Jintao as General Secretary and had made derisive remarks about Xi's fitness to lead the Party. ${ }^{266}$ In June 2015, it was announced that Zhou had been convicted of bribery, abuse of power and intentional disclosure of state secrets. He was sentenced to life in prison. The trial had been held behind closed doors because

\footnotetext{
${ }^{262}$ Lam, above n 246, at 6-7.

263 At 118 .

264 "Report: China to investigate former security czar" The New Zealand Herald (online ed, Auckland, 30 August 2013).

265 Roderic Broadhurst and Peng Wang “After the Bo Xilai Trial: Does Corruption Threaten China's future?” (2014) 56(3) Survival 157 at 165.

${ }^{266}$ Lam, above n 246, at 108.
} 
the case involved information sensitive to state security. This was the first time such a senior leader had been convicted of corruption since the CCP took power in $1949 .{ }^{267}$

In prosecuting Zhou, Xi had broken Deng Xiaoping's unwritten rule, "xing bu shang dafu", which directly translates as "high-ranking officials should not be humiliated by legal punishment". This essentially meant that past and present members of the Politburo Standing Committee were not permitted to prosecute each other. ${ }^{268}$ Breaking this rule benefited $\mathrm{Xi}$ as it showed his strength and determination to root out corruption. ${ }^{269}$ What followed was a very selective excising of Zhou's associates and supporters whose faction occupied important offices in security, Sichuan province and the oil fields. As members of Zhou's faction were detained and prosecuted, their positions were filled by $\mathrm{Xi}$ Jinping's political supporters. ${ }^{270}$ This has given some scholars cause to comment that "all the 'tigers' that have been investigated or prosecuted thus far seem to be Xi's political rivals". ${ }^{271}$ In addition, Xi's anti-corruption campaign "is regime-reinforcing instead of regime-undermining". ${ }^{272}$ In fact, the Anti-Corruption Action Plan actually states that one of its key objectives is maintaining discipline within the CCP in order for the whole party to remain united under $\mathrm{Xi}^{273}$ Therefore, Xi's anti-corruption campaign allows him to consolidate power over the CCP by weeding out rival factions.

Since the downfall of Zhou Yongkang and his supporters, Xi has even broadened the application of his anti-corruption campaign by targeting would-be successors. Sun Zhengcai, who replaced Bo Xilai as the CCP Secretary of Chongqing, was dismissed from his post in July 2017 when the CCP's central committee approved an investigation into alleged corruption. This decision came before the CCP's five yearly Congress when $\mathrm{Xi}$ secured another five-year term as president. Unlike Zhou Yongkang, Sun was not retired but a serving member of the 25 member Politburo at the time of the investigation. He was once tipped for promotion to the Politburo's seven-member standing committee. He was also seen as Xi's potential successor. ${ }^{274}$ Sun was identified most closely with the

\footnotetext{
${ }^{267}$ Celia Hatton "China corruption: Life term for ex-security chief Zhou" $B B C$ (online ed, London, 11 June 2015).

${ }^{268}$ Wang, above $\mathrm{n} 244$, at 189.

${ }^{269}$ Lam, above $n$ 246, at 106.

${ }^{270} \mathrm{Fu}$ Hualing "Weilding the sword: President Xi's new anti-corruption campaign" in S Rose-Ackerman and Paul Lagunes (eds) Greed, Corruption, and the Modern State (Edward Elgar Publishing Limited, Cheltenham, United Kingdom, 25 September 2015) 135 at 137 and 151.

${ }^{271}$ Broadhurst and Wang, above n 265, at 167.

${ }^{272} \mathrm{Fu}$, above $\mathrm{n} 270$, at 134.

273 At 137.

274 "Xi curbs disloyalty as Communist party expels former rising star" The Guardian (online ed, London, 30 September 2017).
} 
China Youth League faction and Xi's predecessor, Hu Jintao. ${ }^{275} \mathrm{He}$ has been replaced by Chen Miner, a former Xi aide, who Xi has known since the early 2000s, giving some commentators at the time cause to question whether $\mathrm{Xi}$ intends Chen to be his successor. $^{276}$

$\mathrm{Xi}$ has also sought to undermine the China Communist Youth League by having it absorbed into the Chinese Academy of Social Sciences and renamed the University of Chinese Academy of Social Sciences. In addition to the organisation coming under fire from the government's CCDI, Xi himself recently published a book in which he viciously criticised the League. Former President $\mathrm{Hu}$ Jintao currently leads the League. Hu's relationship with $\mathrm{Xi}$ apparently soured during Xi's first term in office. It is rumoured that $\mathrm{Xi}$ 's move to dismantle the Youth League is an indirect means by which to halt, $\mathrm{Hu}$ Jintao's protégé, Hu Chunhua's potential rise to power. ${ }^{277}$ It appears that $\mathrm{Xi}$ is determined to use any means available to suppress any actual or potential challenge to his leadership of the CCP. On 11 March 2018, China's Legislature voted almost unanimously to abolish the two-term limit on a Chinese head of state's term of office, paving the way for Xi to remain China's president for life. ${ }^{278}$

\section{E Unilateral Persuasion by China's Security Organs}

China's anti-corruption campaigns, self-styled Operation Foxhunt and Operation Skynet, have allegedly used unilateral techniques of persuasion to convince suspects to "voluntarily" return to China to face prosecution. These techniques allegedly utilise Chinese diaspora as a source of intelligence about suspects and as de facto agents, or having Chinese security cadre pose as tourists to track or harass fugitives and in some cases abduct suspects. ${ }^{279}$ The CCDI has reported itself on the methods it has employed to persuade certain individuals suspected of economic crimes to return to China to face prosecution. Multi-agency taskforces are established to pursue particular suspects and coordinate methods for persuading a suspect's return. Such methods include utilising the suspect's relatives, friends and other important stakeholders to actively convince a

\footnotetext{
${ }^{275}$ Christopher Bodeen "Rising political star in China under investigation for corruption" The Globe and Mail <www.theglobeandmail.com>.

276 Andrei Lungu "Xi Jinping Has Quietly Chosen his Own Successor" Foreign Policy (online ed, Washington, 20 October 2017).

277 Katsuji Nakazawa "Xi silences once-powerful youth league and former president's protégé" Nikkei Asian Review (online ed, Tokyo, 25 September 2017).

278 Sidney Leng "China ends presidential term limits, but what other changes were made to the constitution?" South China Morning Post (online ed, Hong Kong, 11 March 2018).

${ }^{279}$ Nigel Stobbs “The Law and Policy Context of Extradition from Australia to the People's Republic of China" (2017) 7 Victoria U L \& Just J 32, at 42.
} 
suspect to return to China through the use of video recordings or letters persuading the suspect to return. One example involved Chen Yijuan, a Chinese expatriate in the United Kingdom, who was persuaded to return to China and confess in January 2016. He was reportedly told that those who return and confess truthfully to a crime would be dealt with leniently, but those who flee to avoid punishment would be chased and "severely punished according to law". 280

In June 2016, the CCDI reported that Tang Dongmei, a former accountant at the Arts and Crafts Import and Export Co Ltd in Fujian Province, who had fled to Australia in 2008 accused of economic crimes, had voluntarily returned to China and confessed. Other suspects have returned in similar circumstances from Australia. ${ }^{281}$ In December 2018, it was reported that Jiang Lei "voluntarily" returned to China from New Zealand after 11 years. Jiang was formerly a deputy president of China's Association of Automobile Manufacturers and accused of embezzlement. He was among four Chinese fugitives allegedly living in Auckland on a list of China's 22 most wanted corruption suspects which had been released by the Chinese government in May $2017 .^{282}$

\section{F Extradition from New Zealand to China and Xi Jinping's Anti-Corruption Campaign}

The internal workings of factional politics within the CCP is at best a murky world, which necessarily forces outside observers to speculate as to what the Chinese government's true motivations are for prosecuting government officials for corruption. But whatever factional rivalries exist behind such prosecutions it is clear that, like others before it, the current Chinese anti-corruption campaign under President Xi Jinping is being used unevenly as a political tool to suppress rival factions and consolidate power within the CCP. As some commentators have observed: ${ }^{283}$

[A]nti-corruption campaigns, even when ostensibly successful, can sometimes mask other motives, signalling, for example, a political purge or an internal power struggle. Indeed, anti-corruption drives are a proven political and disciplinary weapon within the CCP. The threat posed by anti-corruption activities enables leaders to achieve internal control: party members who oppose current CCP policy or threaten the interests of party bosses are vulnerable to corruption charges.

\footnotetext{
${ }^{280}$ At $42-43$.

281 At 43 .

${ }^{282}$ Sam Sachdeva "Chinese fugitive makes 'voluntary' return from NZ" (17 December 2018) Newsroom $<$ www.newsroom.co.nz>.

${ }^{283}$ Broadhurst and Wang, above n 265, at 166.
} 
Others point out that we should not underestimate the importance that China places on thwarting corruption through repatriating economic fugitives or assume that such repatriation is merely a means by which to suppress political rivals. Corruption is an endemic problem in China that not only threatens the Chinese economy but also political stability in China. ${ }^{284}$

The concerns regarding the underlying motivations of $\mathrm{Xi}$ Jinping's anti-corruption campaign should bring into question the ability of New Zealand's current extradition system to deal with the extradition of a high profile individual accused of corruption in China. Even if the current system is considered adequate to ensure New Zealand's international obligations when extraditing a low profile individual, such as Kyung Yup Kim, it seems fair to assume that the current system's overreliance on diplomatic assurances would not be sufficient to address New Zealand's international obligations with respect to high profile corruption cases, particularly with respect to ensuring protection against torture and fair trial rights. On the other hand, unlike with Kyung Yup Kim's extradition, as a state party to UNCAC New Zealand would be obliged under UNCAC to extradite an individual accused of corruption. Moreover, it is clear that there is a greater likelihood of political interference in cases involving corruption. ${ }^{285}$ There is also a greater risk of torture in cases involving the CCDI, which the CCP leadership prefers to use as their vehicle for combatting corruption rather than the state's legal system. ${ }^{286}$ Unlike fugitives accused of ordinary criminal offending, almost all alleged economic fugitives will have been members of the CCP at the time they left China, bringing them within the jurisdiction of the CCDI. The CCDI's investigative techniques reportedly include the use of the 'shuanggui interrogation system' involving the use of torture. The CCDI is a security agency with extra-legal powers unregulated by China's CPL. ${ }^{287}$ It seems likely that diplomatic assurances alone would be insufficient to quell concerns regarding adequate protections for high profile individuals accused of corruption in China, when the security agency tasked with overseeing the investigation of such individuals is not even subject to Chinese domestic law.

As will be shown in Chapter VII, even a legally binding treaty may not be sufficient to prevent political interference in the prosecution of a high profile individual accused of corruption. This may mean, that for cases involving high profile individuals, the only way

\footnotetext{
${ }^{284}$ Stobbs, above n 279, at 32-35.

${ }^{285} \mathrm{Fu}$ and Peerenboom, above n 128, at 103-104.

${ }^{286}$ Stobbs, above n 279, at 35 .

${ }^{287}$ At 41 .
} 
New Zealand can meet its obligations under $\mathrm{UNCAC}^{288}$ is to conclude a bilateral agreement allowing New Zealand to initiate an extraterritorial prosecution in the event that New Zealand declines to extradite such an individual. The next chapter will examine both New Zealand and China's extraterritorial jurisdictions and consider not only the viability of exercising New Zealand's extraterritorial jurisdiction but also some of the pitfalls associated with embarking on extraterritorial prosecutions.

${ }^{288}$ UNCAC, arts 42(4), 44(18), 46(30) and 47. See Chapter II C4 at 19 above. 


\section{Extraterritorial Jurisdiction and Mutual Assistance in Criminal Matters}

Any analysis of extradition between New Zealand and China would not be complete without also considering the extraterritorial jurisdiction of both countries and mutual assistance in criminal matters. This is because these legal processes supplement the extradition process and can in combination act as an alternative to extradition. The obligation of aut dedere aut judicare, or "extradite or prosecute", is the obligation for a state to extradite an accused who is present on its territory or alternatively to prosecute. This obligation has taken on an increasingly important position in emerging international criminal law treaties that criminalise certain transnational conduct. ${ }^{289}$ This obligation is reflected in China's EL, in that China's blanket refusal to extradite its own citizen's is somewhat compensated for by China's expansive extraterritorial jurisdiction in criminal matters involving its nationals and national interests. New Zealand has already availed itself of China's extraterritorial jurisdiction by agreeing to China's offer to try a Chinese citizen in Shanghai in 2011 for the murder of a taxi driver that occurred in Auckland. ${ }^{290}$ New Zealand's extraterritorial jurisdiction is not as extensive as China's, but it has been increasingly extended in respect of certain kinds of transnational offending. This expansion has occurred as New Zealand has ratified a number of treaties intended to address particular kinds of offending that have increasingly taken on transnational characteristics.

The rise in transnational crime has increased the need for mutual assistance in criminal matters between countries. New Zealand will be increasingly faced with issues surrounding its international obligations and the importance of establishing international channels of communication. A viable means by which New Zealand could better address its international obligations would be for New Zealand to offer to exercise its extraterritorial jurisdiction over an individual sought for extradition as an alternative to granting extradition, thereby circumventing the human rights issues associated with extradition to countries such as China, while at the same time fulfilling its international obligation to combat certain transnational crime. However, if New Zealand were to utilise extraterritorial jurisdiction as an alternative to extradition, the New Zealand government and its prosecuting agencies would have to be cognisant of the jurisdictional and human rights issues that arise in respect of extraterritorial prosecutions. This includes the human

\footnotetext{
${ }^{289}$ Claire Mitchell Aut Dedere Aut Judicare: the Extradite or Prosecute Clause in International Law (Graduate Institute Publications, Geneva, 2009).

290 “Taxi driver murder case continues" The New Zealand Herald (online ed, Auckland, 2 August 2011).
} 
rights issues that can arise when utilising mutual legal assistance between countries to facilitate extraterritorial prosecutions.

\section{A Extraterritorial Jurisdiction}

This section will firstly outline the scope of China's expansive extraterritorial jurisdiction, before considering New Zealand's more limited extraterritorial jurisdiction in relation to certain types of criminal offending.

\section{China's extraterritorial jurisdiction in criminal matters}

China's extraterritorial jurisdiction is expansive, allowing the Chinese courts to exercise jurisdiction over almost any kind of offending anywhere in the world when the offending involves Chinese nationals or the Chinese state. Following the civil law tradition, China asserts jurisdiction over any offending criminalised under the CL perpetrated by a Chinese citizen outside the territory of the People's Republic of China. ${ }^{291}$ In addition, China also asserts jurisdiction over criminal offending perpetrated by a foreign national outside China's territory where the offending is perpetrated against the Chinese state or against a Chinese citizen, unless the criminal offending is not a criminal offence according to the laws of the place where the offending occurred. ${ }^{292}$ Any person who commits a crime outside of China's territory can be investigated with respect to his or her criminal responsibility under Chinese law, notwithstanding such an individual already having been tried in a foreign country. If the person has already received criminal punishment in a foreign country, that individual may be exempted from punishment or given a mitigated punishment in China. ${ }^{293}$

\section{New Zealand's extraterritorial jurisdiction in criminal matters}

This section outlines the scope of New Zealand's extraterritorial jurisdiction for certain kinds of criminal offending in order to consider the extent to which New Zealand could exercise its extraterritorial jurisdiction as a viable alternative to extradition. What follows will examine the extent of New Zealand's jurisdiction over offending in its own territory, before moving on to consider New Zealand's jurisdiction over offending occurring outside its borders.

\footnotetext{
${ }^{291} \mathrm{CL}$, art 7.

${ }^{292}$ Article 8.

${ }^{293}$ Article 10.
} 
(a) New Zealand's territorial jurisdiction over criminal offending

No act or omission conducted outside New Zealand, which would usually constitute an offence under New Zealand law, is an offence unless it is deemed to be so under the Crimes Act 1961 or any other New Zealand enactment. ${ }^{294}$ An offence will be deemed to have occurred in New Zealand firstly where any act or omission forming part of an offence occurs in New Zealand, or secondly, where any event necessary to the completion of an offence occurs in New Zealand. ${ }^{295}$ The first jurisdictional test requires an act or omission forming part of the actus reus of an offence to have occurred in New Zealand. For instance, the act of posting drugs from overseas to an address in New Zealand constitutes the act of "importing" drugs into New Zealand because the act of importation continues until the drugs arrive in New Zealand. ${ }^{296}$ Furthermore, in the case of offending involving the unlawful advertising of medicines, the loading of material in New Zealand onto an overseas web server has been held to be causative of the subsequent display or publication of the material to persons in New Zealand who subsequently access the material, thereby allowing the New Zealand courts to exercise jurisdiction. ${ }^{297}$

The second test is not concerned with whether the conduct constituting a component of the offence has occurred in New Zealand, but instead with whether any event necessary for the completion of an offence has occurred within New Zealand. For example, even if importation did not constitute a continuing act, the arrival of goods into New Zealand would amount to a necessary event that results from the act of importation, thereby providing the New Zealand courts with jurisdiction over the offending. ${ }^{298}$ Similarly, the death of a person in New Zealand will amount to a necessary event allowing the New Zealand courts to exercise jurisdiction over the act of homicide even though the acts or omissions giving cause to the person's death have occurred outside of New Zealand.

The New Zealand courts have held that there is a special rule in respect of the offence of conspiracy. A conspiracy is complete once an agreement to commit an offence has been made. Where an agreement has been made between parties both in New Zealand and abroad, it is possible to regard the agreement as being made in more than one jurisdiction, thereby providing jurisdiction where conduct constituting the making of the agreement

\footnotetext{
${ }^{294}$ Crimes Act 1961, s 6.

${ }^{295}$ Section 7.

${ }^{296}$ Saxton $v$ Police [1981] 2 NZLR 186.

${ }^{297} R v$ Standard 304 Ltd [2008] NZCA 564, [2010] NZAR 194, at [36]-[37].

${ }^{298}$ Tipple v Pain [1983] NZLR 257 at 260.
} 
has occurred in New Zealand. ${ }^{299}$ Alternatively, a conspiracy can be treated as a continuing offence up until the point the object of the conspiracy is achieved. If any of the conspirators does any act or omission in furtherance of the conspiracy in New Zealand, the courts will be able to assert jurisdiction over that conspirator. Accordingly, there is jurisdiction over a conspiracy formed outside New Zealand to import drugs into New Zealand where acts done by New Zealand officials, namely the handling of a letter containing drugs mailed from overseas, are acts within the contemplation of the coconspirators in the performance of the continuing conspiracy. ${ }^{300}$ Nonetheless jurisdiction does not extend to a conspirator that enters into a conspiracy from overseas but never sets foot in New Zealand. ${ }^{301}$

(b) New Zealand's extraterritorial jurisdiction over criminal offending

The New Zealand courts are able to assert extraterritorial jurisdiction over the following specific transnational offences committed wholly outside New Zealand in certain circumstances: ${ }^{302}$

(1) Crimes Act offences committed in the course of carrying out a terrorist act (as defined in s 5(1) of the Terrorism Suppression Act 2002);

(2) dealing in people under 18 for sexual exploitation, removal of body parts, or engagement in forced labour; ${ }^{303}$

(3) participating in an organised criminal group; ${ }^{304}$

(4) smuggling migrants; ${ }^{305}$

(5) people trafficking; ${ }^{306}$

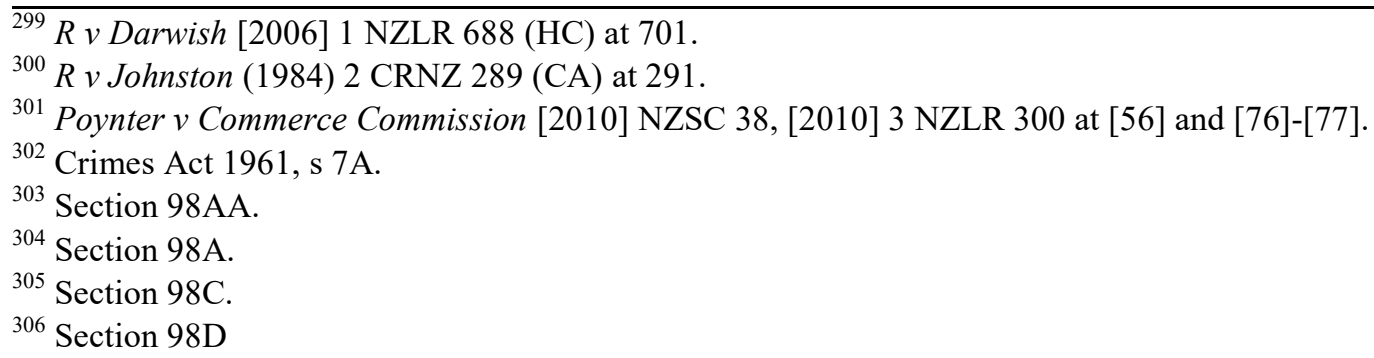


(6) corruption and bribery offences - judicial corruption, bribery of a judicial officer, corruption and bribery of a Minister of the Crown, a Member of Parliament, or a law enforcement officer, and bribery of an official; ${ }^{307}$

(7) conspiring to defeat justice; ${ }^{308}$

(8) corrupting juries and witnesses; ${ }^{309}$

(9) money laundering; ${ }^{310}$

(10) causing disease or sickness in animals; ${ }^{311}$

(11) contaminating food, crops, or water; ${ }^{312}$ and

(12) meeting a young person following sexual grooming. ${ }^{313}$

The various circumstances in which the New Zealand courts have jurisdiction in relation to these specified transnational offences are as follows:

(1) the person charged with a specified offence is connected to New Zealand either by being a New Zealand citizen, ordinarily resident in New Zealand, found in New Zealand and not extradited, or incorporated under the law of New Zealand in the case of a corporate entity; ${ }^{314}$

(2) the alleged acts or omissions forming the specified offence occurred on board a ship or aircraft connected to New Zealand by being a ship registered in New Zealand, a New Zealand Defence Force ship, or a New Zealand aircraft or an aircraft leased to a New Zealand citizen, a person ordinarily resident in New Zealand or a person whose principal place of business is in New Zealand; ${ }^{315}$

\footnotetext{
${ }^{307}$ Sections 100-104 and 105(2)

${ }^{308}$ Section 116.

${ }^{309}$ Section 117.

${ }^{310}$ Section 243.

${ }^{311}$ Section 298A.

${ }^{312}$ Section 298B.

${ }^{313}$ Section 131B.

${ }^{314}$ Section 7A(1)(a)(i)-(iv) and (2A)(a).

${ }^{315}$ Section $7 \mathrm{~A}(1)(\mathrm{b})(\mathrm{i})$-(iv) and (2A)(b).
} 
(3) the person in respect of whom the specified offence is alleged to have been committed is either a New Zealand citizen or ordinarily resident in New Zealand; ${ }^{316}$

(4) a person to be charged with the offence of participating in an organised criminal group, if one of the alleged objectives of the alleged criminal group is to obtain material benefits by the commission in New Zealand of offences punishable by imprisonment for four years or more, or conduct outside New Zealand that would constitute an offence punishable by imprisonment for four years or more, if that conduct had occurred in New Zealand; ${ }^{317}$ or

(5) the alleged acts or omissions forming the offences of smuggling migrants or people trafficking relates to entry of a person into New Zealand, or arranging the bringing of a person into New Zealand. ${ }^{318}$

New Zealand has conferred extraterritorial jurisdiction in respect of these specified offences in response to its international obligations under a number of United Nations conventions and resolutions relating to transnational organised crime, people smuggling and trafficking, terrorism, corruption and child exploitation. ${ }^{319}$

\section{Interrelationship between extraterritorial jurisdiction and extradition}

It is possible for a state to seek extradition of an individual for offending that has occurred outside its borders by way of asserting extraterritorial jurisdiction over the offending concerned. For example, in 2012 the United States was successful in seeking the extradition of two individuals in Scotland for conspiracy and unlawful importation into the United States of precursors used to manufacture methamphetamine. ${ }^{320}$ The

\footnotetext{
${ }^{316}$ Section $7 \mathrm{~A}(1)(\mathrm{c})(\mathrm{i})-(\mathrm{ii})$ and $(2 \mathrm{~A})(\mathrm{c})$.

${ }^{317}$ Sections $7 \mathrm{~A}(\mathrm{~d})$ and $98 \mathrm{~A}(2)(\mathrm{a})$ and $(\mathrm{b})$.

${ }^{318}$ Section $7 \mathrm{~A}(2)$.

319 These include UNTOC, and its Protocol to Prevent, Suppress and Punish Trafficking, Especially Women and Children 2237 UNTS 319 (opened for signature 15 November 2000, enter into force 25 December 2003) and Protocol against the Smuggling of Migrants by Land, Sea and Air 2241 UNTS 507 (opened for signature 15 November 2000, enter into force 28 January 2004); Optional Protocol on the Sale of Children, Child Prostitution and Child Pornography 2171 UNTS 227 (opened for signature 25 May 2000, entered into force 18 January 2002); International Convention for the Suppression of Terrorist Bombings 2149 UNTS 256 (opened for signature 12 January 1998, entered into force 23 May 2001); International Convention for the Suppression of the Financing of Terrorism 2178 UNTS 197 (opened for signature 10 January 2000, entered into force 10 April 2002); and the Anti-Terrorism Resolution of the United Nations Security Council S/Res/1373 (2001).

${ }^{320}$ BH(AP) v The Lord Advocate [2012] UKSC 24.
} 
individuals concerned had been operating an online business while resident in Scotland selling the precursors to customers in the United States via the postal service. Under the Extradition Act 2003 (UK), the definition of an extradition offence requires the alleged conduct to occur in the requesting state's territory. ${ }^{321}$ It is enough that the effects of the offending were intentionally felt in the requesting state's territory, irrespective of where the acts constituting the offence took place. ${ }^{322}$

Under the Extradition Act 1999 (NZ), an individual sought by New Zealand for extradition need only be accused of an extradition offence against the laws of New Zealand. $^{323}$ Similarly an extraditable person is defined as a person accused of having committed an extradition offence against the law of the requesting state. ${ }^{324}$ There is no requirement that the offending occur in New Zealand. Chinese law does not explicitly prescribe any jurisdictional requirements for an extradition from China to a foreign state. The criminal conduct alleged in any request for extradition of an individual from China need only constitute an offence according to the laws of both China and the requesting state. ${ }^{325}$ There is no requirement that the conduct constituting the offence occur in the territory of the requesting state.

It seems inevitable that New Zealand will be faced in the future with either making a request for extradition or determining a request for extradition on the basis of offending that has occurred wholly outside New Zealand or a requesting state. This is most likely to occur in respect of offending via the internet due to a recent proliferation in offending of this kind via what has become known as the "dark web" or "deep web". Drugs such as fentanyl and other synthetic opioids are often produced in China and then sent to users found on the dark web. ${ }^{326}$ Offending related to drug dealing and possession of child pornography through the use of the dark web has recently been uncovered by New Zealand investigators through the use of a "web beacon", a transparent graphic image sent to an online purchaser of child pornography, which reports back to investigators the internet provider address of the computer that requested the file when a document is

\footnotetext{
${ }^{321}$ Extradition Act 2003 (UK), s 137(2)(a).

${ }^{322}$ BH v KAS or H v The Lord Advocate [2011] HCJAC 77 at [52] citing Office of the King's Prosecutor, Brussels v Cando Armas [2006] 2 AC 1, [2005] UKHL 67 at [35].

${ }^{323}$ Extradition Act 1999, s 61.

324 Section 3(a).

${ }^{325} \mathrm{EL}$, art 7(1).

${ }^{326}$ Nathaniel Popper "Dark Wed Drug Sellers Dodge Police Crackdowns" The New York Times (online ed, New York, 11 June 2019) and Interview with Scott Stewart, Vice President of Tactical Analysis at Stratfor (Marco Wermand, Public Radio International, 19 July 2019) <www.pri.org>.
} 
opened on that computer. ${ }^{327}$ Furthermore, the increasing global utilisation of the dark web is beginning to make itself felt in New Zealand through the importation of illicit drugs purchased using cryptocurrency such as Bitcoin on the dark web. ${ }^{328}$ This growing phenomenon will potentially raise complex jurisdictional issues in the future.

\section{Competing jurisdictions and offending on the internet}

Jurisdictional issues most commonly arise in respect of transnational offending involving the manufacture and distribution of child pornography. This is because the development of new technology has made such material easy to transport between states as unlike other illegal materials, such as illicit drugs, it can be transferred between states electronically. ${ }^{329}$ By way of illustration of the jurisdictional difficulties that could arise in respect of such offending consider the hypothetical scenario of a New Zealand citizen filming a child in a sexually explicit manner in China. ${ }^{330}$ The child is a Chinese citizen. The New Zealand citizen then uploads the video file to the dark web which is then accessed by persons all around the world. The video file is later discovered by New Zealand authorities in the possession of persons in New Zealand who have subsequently accessed the file on the dark web and downloaded it. In this scenario China has jurisdiction in respect of the manufacture and subsequent dissemination of the child pornography under Chinese law ${ }^{331}$, because the initial offending relating to filming of the victim occurred in China and the child victim is a Chinese citizen. However, New Zealand could claim jurisdiction under New Zealand law in respect of the subsequent distribution of the child pornography, which is subsequently accessed and downloaded in New Zealand. ${ }^{332}$ There could potentially be further jurisdictional grounds for New Zealand having jurisdiction, if the persons downloading the materials and the New Zealand citizen who made the video were participants in an organised criminal group. If the New Zealand citizen who made the video file remained in China undetected at the time the video file was discovered in the possession of persons in New Zealand, this could potentially lead to a request by New Zealand to China for the extradition of the

\footnotetext{
${ }^{327}$ Hutton $v$ R [2018] NZHC 662.

${ }^{328}$ Smith $v$ Police [2018] NZHC 878.

329 Amanda Haasz "Underneath It All: Policing International Child Pornography on the Dark Web" (2016) 43 Sy J Int L 353 at 356.

330 The idea for this hypothetical scenario was adapted from Haasz, above n 329, at 354 .

331 Such conduct is criminalised under the CL, arts 363-367.

${ }^{332}$ Under s 122(1)(b) of the Films, Videos, and Publications Classification Act 1993 "distribute, in relation to a publication, means...to provide access to the publication (for example, to provide access by means of a public data network to digital content that is or includes the publication)".
} 
New Zealand citizen to face trial in New Zealand on charges of distributing child pornography.

The Optional Protocol on the Sale of Children, Child Prostitution and Child Pornography places an obligation on state parties to criminalise offending involving child pornography "whether such offences are committed domestically or transnationally". ${ }^{333}$ New Zealand and China have both signed and ratified this Optional Protocol. Under the Optional Protocol each state party may establish jurisdiction when the alleged offender is a national, a habitual resident of its territory, or the victim is a national of its territory. Each state party is obliged to establish jurisdiction when the alleged offender of child pornography offences is present in its territory and the harbouring state does not extradite the offender on the ground that the offence has been committed by one of its nationals. ${ }^{334}$ It is clear that jurisdictional problems will arise where the alleged offender is the national of one state and the alleged victim is a national of another. ${ }^{335}$ Under the Optional Protocol, there is also no obligation to prosecute an alleged offender who is not a national of the harbouring state. In practical terms, states attempt to limit their extraterritorial jurisdictions by applying comity, requiring a state to only exert its jurisdiction to a person of another state if it is reasonable to do so, meaning that the state with the greatest interest should apply its jurisdiction. Of course applying such a test would not always resolve such jurisdictional issues. ${ }^{336}$

Taking the hypothetical scenario referred to above, it is worth considering what would likely take place were New Zealand to request extradition of the New Zealand citizen who produced and uploaded the video file onto the dark web. Under Chinese law, the Supreme People's Procuratorate is able to notify the SPC and the Chinese Ministry of Foreign Affairs of its opinion as to whether to institute criminal proceedings. ${ }^{337}$ A request for extradition may be rejected if China has criminal jurisdiction over the offence and criminal proceedings are being instituted against the individual sought for extradition or preparations are being made for such proceedings. ${ }^{338}$ Accordingly, China could reject the request on the basis that it has decided to prosecute the alleged offending itself. Alternatively, the State Council could decide to postpone the extradition while criminal

\footnotetext{
333 Optional Protocol on the Sale of Children, Child Prostitution and Child Pornography 2171 UNTS 227 (opened for signature 25 May 2000, entered into force 18 January 2002), art 3.

334 Article 4.

335 Amanda Haasz, above n 329, at 368-369.

336 At 369.

${ }^{337}$ EL, art 21.

${ }^{338}$ Article 9(1).
} 
proceedings are initiated in China ${ }^{339}$, although it seems likely that such measures would only be resorted to in a case where the individual sought is facing prosecution for offending unrelated to the offending which is the subject of the request for extradition.

\section{Extraterritorial prosecutions and human rights issues}

The two most common issues that arise in respect of extraterritorial prosecutions is firstly the lack of clear guidelines for prosecutors as to how they should exercise extraterritorial jurisdiction and, secondly, the power imbalance between an accused and the prosecution in respect of their relative evidence gathering capabilities.

\section{(a) Lack of prosecution guidelines}

There is often a risk that the discretion as to whether to exercise extraterritorial jurisdiction becomes politicised and open to abuse. One such example involved Julian Moti who was deported from the Solomon Islands to Australia, where he was prosecuted for child sex offences that had allegedly occurred in Vanuatu. Moti's appointment as Attorney-General was terminated three days before his deportation. This led to much media attention and speculation as to the political motives of the Australian government in pursuing the prosecution. ${ }^{340}$ Jurisdiction was asserted on the basis of Moti's Australian citizenship even though he had been a citizen of Vanuatu at the time the offending allegedly occurred. Moti applied for a stay of the proceedings, arguing that the prosecution was an abuse of process. Australia had no ability to compel the witnesses residing in Vanuatu to give evidence. This led the Australian Federal Police to make payments to the main witness, which were described as "living expenses". The application for a stay was initially granted on the basis that the payments made to the main witness and other witnesses resident in Vanuatu brought the administration of justice into disrepute due to the payment amounts exceeding merely subsistence support. ${ }^{341}$ This decision was later overturned and Moti appealed to the High Court of Australia. The High Court held that the payments to witnesses was not an abuse of process, but ordered a stay of the proceedings on the grounds that the prosecution was an abuse of process due to Australian officials having facilitated Moti's deportation from the

\footnotetext{
339 Article 42.

340 Danielle Ireland-Piper "Extraterritorial Criminal Jurisdiction: Does the Long Arm of the Law Undermine the Rule of Law?" (2012) 13 Melb J Int'l Law 122 at 151.

${ }^{341} R v$ Moti [2009] QSC 407 at [92].
} 
Solomon Islands knowing that his deportation was unlawful under Solomon Island's law. ${ }^{342}$

Julian Moti's case highlights the deficiencies in the current ad hoc and often unilateral basis by which states exert extraterritorial jurisdiction. The discretionary power whether to exercise extraterritorial jurisdiction is adjudicated by domestic courts primarily by focusing on the rights of states through such principles as the comity of nations and state sovereignty rather than protecting the rights of the individuals concerned. In New Zealand, the Crown must seek the Attorney-General's consent if jurisdiction over an individual is claimed in respect of the specific offences where extraterritorial jurisdiction is provided for by the Crimes Act $1961 .{ }^{343}$ Although this does provide a check on the prosecutorial discretion to exercise extraterritorial jurisdiction in New Zealand, it by no means ensures that political motivations will not interfere in the way extraterritorial prosecutions are conducted.

Furthermore, there is little in the way of guidance on how prosecuting authorities should exercise extraterritorial jurisdiction. There is a risk that political motivations rather than the rights of the individuals concerned would influence the Attorney-General's decisionmaking with respect to the provision of consent without any clear international guidelines around exercising extraterritorial jurisdiction. It is precisely because exercising extraterritorial jurisdiction touches on matters involving foreign relations that consent of the Attorney-General is required ${ }^{344}$, not because of concerns relating to the protection of the individuals concerned. The international community would benefit substantially by moving towards a treaty-based system when exerting extraterritorial jurisdiction that encompasses both the rights of individuals as well as state sovereignty. Clear guidelines with respect to how the prosecutorial discretion to assert extraterritorial jurisdiction should be exercised could be provided for in a 'model law' similar to those developed under UNTOC. ${ }^{345}$

(b) Equality of arms

Another issue that will inevitably arise in cases involving extraterritorial prosecutions is a disparity in the relative abilities of the prosecution and defence to obtain evidence and assistance abroad, in the jurisdictions where the offending allegedly occurred. An

\footnotetext{
${ }_{342}$ Moti v The Queen (2011) 238 ALR 393 at 412.

${ }^{343}$ Crimes Act 1961, s 7B.

${ }^{344}$ Crown Law Solicitor-General's Prosecution Guidelines (1 July 2013) at 13.

${ }^{345}$ Ireland-Piper, above n 340, at 157.
} 
example of how this disparity can lead to human rights abuses is demonstrated by another Australian case involving the prosecution of Frederick Martens. Martens was an Australian citizen prosecuted for allegedly engaging in sexual intercourse with a 14 year old girl while residing and working as a pilot and businessman in Papua New Guinea. After facing trial in Australia in October 2006, Martens was convicted and spent several years in prison before eventually being pardoned after further evidence was revealed showing that Martens was not with the complainant at the time the offending had allegedly occurred. ${ }^{346}$ The fresh evidence was ultimately obtained by Martens' family.

Martens was interested in purchasing a resort located near the complainant's village. The complainant's father was the principal traditional landowner of the lands around the resort at the time. The owner of the resort had been involved in a dispute with the traditional landowners over the resort, meaning that Martens had included the traditional landowners in his negotiations regarding purchasing of the resort. In an attempt to establish goodwill with the traditional landowners, he offered to sponsor the complainant to attend high school in Cairns. The offending was alleged to have occurred in September 2001 when Martens flew the complainant to Port Moresby, where she alleged she had had sexual intercourse with Martens at his home. The complainant's mother gave evidence that Martens had flown the complainant to Port Moresby on two occasions. Martens gave evidence at his trial that he had flown the complainant to Port Moresby only once in August 2001 producing his pilot's logbook in support of his evidence. Martens gave evidence that he and the complainant had stayed at a friend's home sleeping in separate rooms. Marten's friend gave evidence that supported Marten's account of what occurred. $^{347}$

Martens was unsuccessful in his appeal against conviction in the Queensland Court of Appeal in 2007. The principal appeal ground related to the sufficiency of evidence to convict Martens and whether a direction should have been given to the jury warning of the potential issues with the evidence. The Queensland Court of Appeal held that it was open to the jury to find the evidence of Martens' logbook unpersuasive due to it being handwritten and not independently reviewed. ${ }^{348}$ From the time of his arrest, Martens claimed that there were civil aviation records which would confirm the dates in his

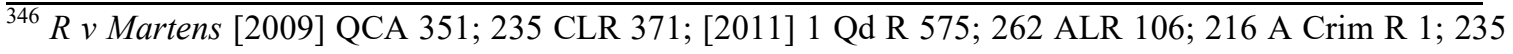
FLR 371 (QSC).

${ }^{347}$ Melissa Curley and Elizabeth Stanley "Extraterritorial Jurisdiction, Criminal Law and Transnational Crime: Insights from the Application of Australia's Child Sex Tourism Offences” (2016) 28 Bond LR 169 at $174-178$.

348 At 179 .
} 
logbook. The Australian Federal Police had made enquiries regarding such records, but were informed that records of flights were not held for longer than three months. The Papua New Guinean Police gave evidence at trial that no records of the relevant flight could be recovered. Due to enquiries conducted by members of Martens' family, records held by the Civil Aviation Authority were located in March 2008. This fresh evidence confirmed that the plane Martens flew had not flown to Port Moresby at the time the offending was alleged to have occurred by the complainant. ${ }^{349}$

The Martens case demonstrates how an extraterritorial prosecution can seriously impede a defendant's ability to source exculpatory evidence and ultimately offer an effective defence. What is startling about Martens' case is that the Commonwealth Director of Public Prosecutions actually argued that Martens should not be pardoned because the flight records existed at the time of the trial and Martens should have obtained the evidence earlier. ${ }^{350}$ A defendant to an extraterritorial prosecution will not usually have a legal right to disclosure of evidence held by authorities in a foreign jurisdiction, nor the ability to utilise the authorities in a foreign jurisdiction to facilitate evidence gathering. Unlike the Australian Federal Police who were able to utilise local law enforcement agencies to attempt to locate the flight records, Martens was forced to rely on members of his family to source the exculpatory evidence. ${ }^{351}$

The obvious answer to this relative disadvantage to a defendant facing an extraterritorial prosecution is for the defendant to be provided with the ability to seek mutual assistance in criminal matters through foreign law enforcement agencies. ${ }^{352}$ The Mutual Assistance in Criminal Matters Act 1992 (NZ) (MACMA) does not explicitly state whether a defendant facing criminal proceedings in New Zealand can utilise the Act to make a request to the Attorney-General to make a mutual legal assistance request to a foreign jurisdiction, but it is generally accepted that the Attorney-General can make a request on behalf of a defendant as well as the prosecution. ${ }^{353}$ The Law Commission has recommended that its draft Mutual Assistance in Criminal Matters and for Recovery of Criminal Proceeds Act should explicitly provide for defendant requests for information from foreign jurisdictions under the proposed legislation. ${ }^{354}$

\footnotetext{
${ }^{349}$ At 181.

${ }^{350} R v$ Martens, above n 317, at [170].

${ }^{351}$ Curley and Stanley, above n 347, at 189-190.

${ }^{352}$ At 195.

${ }^{353}$ Law Commission, above n 10, at 228.

${ }^{354}$ Law Commission, above n 2, at 113.
} 


\section{Provision of an alternative to extradition in certain cases}

William Yan (aka Bill Liu) is alleged to have committed a large scale fraud involving the theft of some NZD\$129 million in 2000 and 2001. ${ }^{355}$ The Commissioner of Police filed an application for restraining orders in August 2014 successfully restraining some \$30-40 million worth of assets in New Zealand based on alleged money laundering. ${ }^{356}$ The Commissioner sought further profit forfeiture orders of approximately $\$ 88.2$ million. ${ }^{357}$ The parties agreed to settle the claims by way of a profit forfeiture order of an undisclosed amount in 2016. The settlement was conditional upon Yan reaching an agreement with the Chinese government. ${ }^{358}$ Thomas $\mathrm{J}$ approved the conditional settlement, but held that the Court had no jurisdiction to approve the conditional aspects of the agreement with the Chinese government which were solely for the parties to agree among themselves. ${ }^{359}$ The agreement with the Chinese government meant that the settlement included an additional clause that Yan be charged for money laundering in New Zealand. ${ }^{360}$ Separate to the settlement agreement, Yan and the Chinese authorities agreed to Yan returning to China to face prosecution for the alleged fraud. This was conditional on Yan being permitted to return to New Zealand immediately following trial irrespective of the sentence imposed. The Commissioner of Police agreed to act consistently with the agreement reached between Yan and the Chinese authorities. ${ }^{361}$ The Chinese government received approximately \$27 million from the forfeiture while New Zealand kept the balance of $\$ 15$ million. ${ }^{362}$

Although it may seem strange that China would agree to return Yan at the conclusion of his trial in China without subjecting him to sentence, this conduct is actually in accordance with Chinese extradition law. The EL allows China to postpone an extradition while approving it where China is conducting criminal proceedings against the individual sought for extradition. Where postponement may seriously impede the criminal proceedings in the requesting state, the individual sought may be extradited temporarily on condition that the requesting state undertakes to send back the individual

355 Commissioner of Police v William Yan [2016] NZHC 919 at [5].

356 At [8]-[11].

357 At [13].

${ }^{358}$ At [20]-[22].

${ }^{359}$ At [38].

${ }^{360}$ Commissioner of Police v William Yan [2016] NZHC 1822 at [4](b).

${ }^{361}$ At [6]-[7].

362 Jared Savage "Controversial Citizen William Yan AKA Bill Liu admits money laundering of 'significant sums"” The New Zealand Herald (online ed, Auckland, 10 May 2017). 
unconditionally and immediately after concluding the relevant proceedings. ${ }^{363}$ This characteristic of Chinese extradition law may partly explain why the Chinese authorities were amenable to undertaking to return Yan at the conclusion of his trial in China so that New Zealand could proceed with its own prosecution of Yan for money laundering.

William Yan's case could provide a model for an alternative means by which to deal with alleged economic fugitives from China currently residing in New Zealand. Instead of individuals accused of corruption in China being extradited to China for prosecution, such individuals could instead be prosecuted in New Zealand for the offending that allegedly occurred in China under New Zealand's extraterritorial jurisdiction. ${ }^{364}$ An extradition treaty with China should allow either state party to offer to try an individual sought for extradition by the other party under that party's extraterritorial jurisdiction as an alternative to extradition. Of course, New Zealand would only be able to make such an offer in circumstances where the New Zealand courts have jurisdiction over the offending concerned. In cases involving economic fugitives, the applicable offending would involve laundering of proceeds of crime in China. Consideration should be given to expanding the scope of New Zealand's extraterritorial criminal jurisdiction in respect of individuals requested for extradition under a bilateral extradition treaty with China. Furthermore, an extradition treaty with China should also include a comprehensive asset sharing regime to determine how proceeds of crime should be shared between the parties at the conclusion of an extraterritorial prosecution. ${ }^{365}$

\section{B China and New Zealand's Mutual Assistance in Criminal Matters}

This section will consider certain issues that could arise as a result of reliance on mutual legal assistance with China when undertaking an extraterritorial prosecution. First, this section will briefly outline the relevant law applicable to mutual legal assistance between New Zealand and China, before considering the risk of individuals resident in China being subject to torture as a result of New Zealand making a request to China for mutual legal assistance.

\footnotetext{
${ }^{363}$ EL, arts 42 and 43.

${ }^{364}$ Crimes Act 1961, s 7A.

${ }^{365}$ Eleanor Ross has proposed that an asset sharing regime be part of an extradition treaty between China and the United States. See Eleanor Ross "Increasing United States-China Cooperation on Anti-Corruption: Reforming Mutual Legal Assistance” (2018) 86 Geo Wash L Rev 839.
} 
1 Treaty between New Zealand and the People's Republic of China on Mutual Legal Assistance in Criminal Matters

China and New Zealand already have a treaty relating to mutual assistance in criminal matters called the Treaty between New Zealand and the People's Republic of China on Mutual Legal Assistance in Criminal Matters. ${ }^{366}$ This treaty places an obligation on the parties to assist each other with investigations, prosecutions and other proceedings in respect of criminal matters. ${ }^{367}$ The treaty applies only to legal assistance in criminal matters, such as taking evidence from persons, serving documents, executing requests for search and seizure, arranging for persons to give evidence in the requesting state and restraining proceeds of crime. ${ }^{368}$ The treaty does not apply to the extradition of individuals between the state parties, the transfer of sentenced persons for serving their sentence, or the transfer of criminal proceedings. ${ }^{369}$ The treaty provides the following discretionary grounds for refusing requests: ${ }^{370}$

(1) the request relates to conduct which would not constitute an offence under the laws of the requested party;

(2) the request relates to an offence of a political or military character;

(3) there are substantial grounds for the requested party to believe that the request has been made for the purpose of investigating, prosecuting, punishing or taking other proceedings against a person on account of that person's race, sex, religion, nationality or political opinions, or that that person's position may be prejudiced for any of those reasons;

(4) the requested party is in the process of or has terminated criminal proceedings or has already rendered a final judgment against the same suspect or accused for the same offence as that to which the request relates;

\footnotetext{
$\overline{366}$ Treaty between New Zealand and the People's Republic of China on Mutual Legal Assistance in Criminal Matters, New Zealand-People's Republic of China [2008] NZTS 1 (signed 6 April 2006, entered into force 1 January 2008).

${ }^{367}$ Article 1.1.

${ }^{368}$ Article 1.3 .

${ }^{369}$ Article 1.4.

${ }^{370}$ Article 3.
} 
(5) the requested party considers that the assistance requested lacks substantial connection with the case; or

(6) the requested party determines that the execution of the request would impair sovereignty, security, public order, or other essential public interests.

There are no mandatory provisions for refusing a request for assistance. This is in line with the Model Treaty on Mutual Assistance in Criminal Matters. ${ }^{371}$ Notably there is no ground for refusing a request where the request relates to an offence which carries the death penalty. This is contrary to the discretionary ground under MACMA for refusing a request where a request relates to a prosecution or punishment of a person for an offence in respect of which the person may be or has been sentenced to death. ${ }^{372}$ There is no guidance under MACMA as to whether the provisions of the Act or a treaty should be preferred when considering a request. In New Zealand the regulations bringing a treaty into force do not state any limitations or exceptions to the legislation that are applicable. Any inconsistencies between a treaty and MACMA, leads to ambiguity as it is not clear whether the treaty provides an exception to the Act. ${ }^{373}$ However, the treaty provides that a requested party shall give reasons for a decision to refuse a request where one of the grounds for refusal applies or execution of the request would be contrary to fundamental principles of the requested party's national law. ${ }^{374}$ This indicates that either party to the treaty can refuse a request when such a request is contrary to its domestic law.

\section{Mutual assistance in criminal matters with China and the risk of torture}

MACMA does not provide a ground for refusing a request where there is a risk of a person being subject to torture as a result of granting a request. However, the Act does have a provision allowing the Attorney-General to refuse a request where the provision of the assistance would be likely to prejudice the safety of any person, whether that person is in New Zealand or not. ${ }^{375}$ This means that a request could be refused where granting the request may result in a risk of any person being subject to torture. Notwithstanding this provision, the Law Commission has noted that the failure of the Act to provide an explicit ground for refusing a request where there is a risk of torture is "somewhat

\footnotetext{
${ }_{371}$ Model Treaty on Mutual Assistance in Criminal Matters GA Res 45/117, A/Res/45/117 (1990).

${ }^{372}$ Mutual Assistance in Criminal Matters Act 1992 [MACMA], s 27(2)(ca).

${ }^{373}$ Law Commission, above n 10, at 155.

${ }^{374}$ Treaty between New Zealand and the People's Republic of China on Mutual Legal Assistance in Criminal Matters, above n 365, art 3.2.

${ }^{375}$ MACMA, s 27(2)(f).
} 
anomalous". ${ }^{376}$ The Commission surmises that the reason for the omission of a torture ground in the Act is because CAT explicitly includes an obligation not to extradite where there is a risk of torture, whereas CAT is silent with respect of mutual legal assistance. This silence could be due to there being less risk of a person being subject to torture as a result of granting a request for mutual assistance in criminal matters compared with the substantial risk when granting a request for extradition of an individual to a foreign state. Nonetheless, notwithstanding this distinction, the Law Commission has concluded that the significance of the prohibition against torture under CAT and customary international law means that New Zealand's domestic law should include a torture ground for refusing a request for mutual assistance. ${ }^{377}$ Reflecting this conclusion, the Commission's proposed Mutual Assistance in Criminal Matters and for Recovery of Criminal Proceeds Bill ${ }^{378}$ includes an explicit ground for refusing a request for assistance where "any person will be subjected to torture, or inhumane or degrading treatment, if the assistance is provided". 379

The obvious issue with this approach is that it does not deal with a situation where making a request for assistance could result in an individual being subject to torture in a requested state. The risks involved in requesting mutual legal assistance with China can be demonstrated by a well-known United States' case commonly called the "Goldfish case". 380 In 1988, the Drug Enforcement Administration (DEA) learned that the authorities in China had intercepted a shipment of heroin, bound for San Francisco, concealed in the cavities of dead goldfish. The DEA and the Chinese authorities then cooperated in a "controlled delivery" of the heroin by placing a "beeper" in the controlled delivery from Shanghai to San Francisco. The delivery was made and arrests followed in Hong Kong, China and San Francisco. Wang Zongxiao was arrested for his part in the conspiracy by Chinese police in Shanghai. ${ }^{381}$ He was subject to repeated interrogations involving sleep deprivation, numerous beatings and on one occasion electrocution with a cattle prod to extract forced confessions. ${ }^{382}$

Effectively granting a United States government request for mutual legal assistance, Chinese officials collaborated with United States' officials to bring Wang to San

\footnotetext{
${ }^{376}$ Law Commission, above n 10, at 175.

377 At 175.

378 This draft Bill had not been introduced in Parliament at the time of writing this thesis.

${ }^{379}$ Law Commission, above n 2, at 252.

${ }^{380}$ Xiao v Reno 837 F Supp 1506 (ND Cal 1993) and Wang v Reno 81 F 3d 808 (9th Cir 1996).

${ }^{381}$ Xiao v Reno, above n 380, at 1514.

${ }^{382}$ At 1512-1513.
} 
Francisco to serve as a prosecution witness in a trial against his alleged co-conspirators, Leung Tuk Lun, Chico Wang and Andrew Wong. Wang Zongxiao had initially denied that Leung was present at the delivery of heroin in Shanghai, but after being subjected to torture changed his statement placing Leung at the scene. Hong Kong officials had declined to prosecute Leung who had originally been arrested in Hong Kong because they suspected that Wang's confession was coerced and untrue. ${ }^{383}$ During the trial, Wang initially testified that Leung was present when the heroin was delivered in Shanghai, but later changed his story testifying that Leung was not present. When first called to give evidence, Wang unexpectedly requested to speak to the Judge. Because of what was discussed, Wang was appointed a lawyer. What followed was unprecedented. Wang's testimony changed after he was granted a preliminary injunction barring his return to China. He had obtained this injunction through his court appointed lawyer after disclosing that he had been subject to torture while detained in police custody in China. Rather shockingly, some members of the DEA, Attorney-General's office and the prosecution team knew that Wang's confessions were very likely the result of torture, but sought his participation in the trial in any case. ${ }^{384}$

The Goldfish case demonstrates the difficulties that could arise in conducting an extraterritorial prosecution on the basis of mutual legal assistance with China in criminal matters. Although requests for obtaining the attendance of individuals resident in foreign jurisdictions to provide evidence in New Zealand must be voluntary, ${ }^{385}$ there are obvious risks that evidence obtained from witnesses resident in China may have been obtained through the use of torture, particularly if a witness from China was a co-conspirator subject to detention and prosecution in China. Protections for individuals requested to give evidence from overseas are limited because protections for individuals, who agree to assist under the Treaty, focus exclusively on protections for individuals while in the requesting state not the requested state. ${ }^{386}$ Finally, China is obliged under the Treaty to obtain statements from individuals in respect of criminal matters concerning New Zealand when requested to do so by New Zealand. ${ }^{387}$ This means that there is also a risk of torture being used in circumstances where New Zealand requests the Chinese

\footnotetext{
383 Wang $v$ Reno, above $\mathrm{n} 380$, at 811.

${ }^{384}$ Xiao v Reno, above n 380, at 1536-1537.

${ }^{385}$ MACMA, s 12.

386 Treaty between New Zealand and the People's Republic of China on Mutual Legal Assistance in Criminal Matters, above n 365, art 12. Protection under art 12.4 only extends to persons traveling to give evidence or assisting in investigations under arts 10 or 11 and does not extend to persons providing statements under art 9.

${ }^{387}$ Article 9.
} 
authorities to obtain a statement from a witness, particularly if that witness is also a cooffender and also criminally liable in China.

\section{Aut Dedere Aut Judicare Clause}

Provision should be made under an extradition treaty with China for a requested party to decline to extradite an individual, but instead offer to prosecute the individual under the extraterritorial jurisdiction of the requested party. The requesting party would then have the discretion to decline such an offer. This would be particularly appropriate in cases like William Yan's involving large scale fraud and money laundering of large sums. Although serious consideration should be given to expanding the scope of New Zealand's extraterritorial jurisdiction in respect of individuals requested for extradition under an extradition treaty with China. This would allow New Zealand's prosecuting agencies greater ability to prosecute extraterritorially as an alternative to extradition to China. The treaty should also provide for an asset sharing regime in cases involving large scale economic crime to compensate the requested party for the costs associated with extraterritorial prosecutions and mutual assistance. It seems likely that diplomatic assurances alone would not be sufficient to safeguard a high profile individual's fair trial rights or provide protection from torture in cases involving allegations of corruption and fraud in respect of Chinese government institutions or state owned enterprises. Utilisation of New Zealand's extraterritorial jurisdiction would be a viable means by which to prosecute such individuals in line with New Zealand's obligations under UNCAC. This would also avoid the many human rights issues arising in respect of an extradition of such an individual to China.

Notwithstanding this conclusion, the natural corollary that flows from utilising a requested party's extraterritorial jurisdiction as an alternative to extradition is that the parties' governments and prosecuting authorities must be cognisant of the human rights issues that arise in respect of extraterritorial prosecutions. Defendants to such cases must be able to utilise mutual legal assistance between the parties to obtain exculpatory evidence. Prosecutors and government officials must not be swayed by international or domestic political pressure when deciding whether to prosecute such individuals extraterritorially, particularly when representing a powerful nation such as China. Furthermore, due to extraterritorial prosecutions necessarily requiring mutual legal assistance, government officials and prosecutors would need to be cognisant of the risks involved, not only with respect to an accused's rights, but also the risks to other individuals that may be called upon to provide statements and give evidence at trial, 
particularly where those other individuals are alleged co-conspirators who could face prosecution in respect of the alleged offending as a result of a request for mutual legal assistance.

The next chapter undertakes an analysis of the Law Commission's recommendations for modernising New Zealand's extradition law and whether those recommendations address the intrinsic problems arising from reliance on assurances to address human rights concerns. As will be seen the Law Commission's overemphasis on using New Zealand's domestic legislation to protect individuals subject to extradition requests raises more questions than it provides answers regarding whether domestic statute can ever truly provide better protections for extradited individuals than legally binding extradition treaties. 


\section{The Impact of the Law Commission's Recommendations on Extradition Practice between China and New Zealand}

The Law Commission published an issues paper ${ }^{388}$ in December 2014 after it was asked to review the Extradition Act 1999 and MACMA. After receiving submissions the Commission published a report $^{389}$ in February 2016 outlining its proposals for replacement of the current legislation along with draft Bills to replace both Acts. This chapter will focus on the Law Commission's review and proposals for the Extradition Act 1999. The Commission's proposal before submissions were even received was to replace the Extradition Act 1999 with a new statute due to perceived problems with the existing legislation's “fundamental underpinnings as well as technical aspects such as the procedural requirements and the sharing of roles". ${ }^{390}$ The Commission's proposals have essentially amounted to a streamlining of the current legislation with its focus on reducing delay and complexity of the process rather than any particularly radical change to the current legislation. The most comprehensive proposed changes relate to procedural aspects of the process involving the establishment of a Central Authority and a more significant decision-making role taken by the courts. Nevertheless, the Law Commission's approach fails to grasp the increasingly important role that bilateral treaties will play in extradition with countries such as China in the future and the Commission's proposed legislation does nothing to change the current extradition system's overreliance on diplomatic assurances to ensure New Zealand meets its international obligations.

\section{A Grounds for Refusing Extradition}

The draft Bill outlines mandatory grounds on which the court must refuse extradition in clause 20 of the draft Bill, and mandatory and discretionary grounds for refusal by the Minister in clause 21. A major concern for the Commission in drafting the grounds was to avoid consideration of the same grounds by both the Court and the Minister of Justice. ${ }^{391}$ All of the proposed statutory grounds for refusing extradition are mandatory. The only discretionary grounds are those limited grounds specified in a bilateral treaty between New Zealand and the requesting country relating to citizenship and

\footnotetext{
${ }^{388}$ Law Commission, above n 10.

${ }^{389}$ Law Commission, above $\mathrm{n} 2$.

${ }^{390}$ Law Commission, above n 10, at 5 .

${ }^{391}$ Law Commission, above n 2, at 40.
} 
extraterritorial jurisdiction, or which must be considered by an executive branch of government. $^{392}$

1 Grounds for the court to refuse extradition

\section{Grounds on which court must refuse extradition}

The grounds on which the court must refuse extradition are as follows:

(a) that there are substantial grounds for believing the respondent would be in danger of being subjected to torture or to cruel, inhumane, or degrading treatment or punishment in the requesting country:

(b) that the relevant extradition offence is a political offence:

(c) that the extradition of the respondent -

(i) is actually sought for the purpose of prosecuting or punishing the respondent on account of his or her race, ethnic origin, religion, nationality, age, sex, sexual orientation, disability, or other status, or political opinions; or

(ii) may result in the respondent being prejudiced at trial or punished, detained, or restricted in his or her personal liberty because of any of those grounds:

(d) that, if the respondent were tried for the relevant extradition offence in New Zealand, the respondent would be entitled to be discharged because of a previous acquittal, conviction, or pardon:

(e) that the extradition of the respondent would be unjust or oppressive for reasons including (but not limited to) -

(i) the likelihood of a flagrant denial of a fair trial in the requesting country; or

(ii) exceptional circumstances of a humanitarian nature:

(f) that a ground applies on which extradition must be refused under a bilateral extradition treaty.

The first significant change to the mandatory grounds for refusal is to expand the torture ground to include cruel, inhumane and degrading treatment ${ }^{393}$, in line with the wording of the Immigration Act 2009. This recommendation essentially brings the legislation in line with New Zealand's international obligations under CAT and the ICCPR. ${ }^{394}$ The discriminatory grounds for refusal have been expanded to expressly include "age", "sexual orientation" and "disability". 395 The "unjust or oppressive ground", described by

\footnotetext{
392 At 42. See clause 21(2) of the Law Commission's draft Extradition Bill.

${ }^{393}$ Clause 20(a).

${ }^{394}$ Law Commission, above n 2, at 194.

${ }^{395}$ At 195.
} 
the Law Commission as "a corner-stone" of the Commission's reform, ${ }^{396}$ is essentially a codification of the current international jurisprudence relating to refusal on grounds relating to a 'flagrant denial' of fair trial rights ${ }^{397}$ currently covered by the catch-all ground for refusal in the Extradition Act 1999: "any other reason that the Minister considers the person should not be surrendered". 398 The main legislative differences are that the ground has been expressly provided for in the draft Bill and it has been elevated to a mandatory ground for refusing extradition. However, the adoption of "a high threshold" 399 for the judicial finding of a likely breach of fair trial rights in the requesting country arguably flies in the face of current New Zealand case law on the topic. In Kyung Yup Kim v Minister of Justice ${ }^{400}$, the Court of Appeal had reservations regarding the use of the word "flagrant" because it has a tendency to denote a "high-handed, brazen or scandalous conduct". 401 The Court also did not think that the use of the term "high test" was useful because "it deflects from the critical inquiry". ${ }^{402}$ The Court considered that the "appropriate threshold is whether there is a real risk of a departure from the standard such as to deprive the defendant of a key benefit of the right in question". ${ }^{403}$

\section{Grounds for the Minister to refuse extradition}

\section{Grounds on which Minister must or may refuse extradition}

(1) The ground on which the Minister must refuse extradition is that the respondent has been, or may be, sentenced to death in the requesting country for the extradition offence and the requesting country has not given a satisfactory assurance to the Minister that the sentence will not be carried out. A ground on which the Minister may refuse extradition is a ground that -

(a) applies under a bilateral extradition treaty to which New Zealand and the requesting country are both party; and either -

(i) relates to citizenship or extra-territorial jurisdiction; or

(ii) is identified in the treaty as a ground that must be considered by a representative of the executive branch of government.

The most significant change to the ground for refusing extradition on the basis that an individual will or may be subject to the death penalty in a requesting country is the

\footnotetext{
${ }^{396}$ At 196.

${ }^{397}$ Soering $v$ United Kingdom (1989) 11 EHRR 439 (ECHR).

${ }^{398}$ Extradition Act 1999, s 30(3)(e).

${ }^{399}$ Law Commission, above $\mathrm{n} 2$, at 196.

${ }^{400}$ Kyung Yup Kim v Minister of Justice, above $\mathrm{n} 94$.

${ }^{401}$ At [178].

${ }^{402}$ At [178].

${ }^{403}$ At [179].
} 
mandatory nature of the proposed provision. The Minister no longer has discretion as to whether to refuse extradition or seek assurances. Instead the Minister must obtain an assurance that the death penalty will not be imposed if the death penalty is a possible sentence for the offence under the law of the requesting state. ${ }^{404}$ There is no definition of an "assurance" or indeed a "satisfactory assurance" contained in the Commission's draft Bill. ${ }^{405}$ The only discretionary ground under the proposed legislation is a ground specified under a bilateral treaty which relates to citizenship and questions of extraterritorial jurisdiction, or is identified in the treaty as a ground that must be considered by the executive branch of government.

\section{B Procedural Changes}

The most striking recommendations relate to changes to procedure for administering extradition requests and decision-making. The first is the proposal to establish a Central Authority with the power to vet incoming requests and liaise with requesting countries to improve requests. ${ }^{406}$ The vetting process will consist of the Central Authority assessing individual requests to determine whether there is a reasonable prospect of extradition. This would involve a preliminary assessment of whether a humanitarian ground might be likely to prevent extradition. The Central Authority would have a gatekeeping role in the initial assessment as to whether an extradition proceeding can commence. ${ }^{407}$ The Central Authority would in practice be the Attorney-General supported by the Crown Law Office. $^{408}$ It would take over certain preliminary roles currently carried out by the Minister of Justice, namely formerly receiving requests and deciding whether to initiate proceedings. $^{409}$

The second major proposed change is the significant increase in the decision-making role of the courts. The rationale for this shift is the view that law enforcement decisions should be undertaken by a non-political actor, but there is also another more practical reason for favouring the courts. This other reason is that the Minister's decisions are almost inevitably subject to judicial review often resulting in substantial delay. Nevertheless, the Commission recognised that some grounds, such as the death penalty, torture and inhumane treatment might better be assessed by the Minister because of the importance of diplomatic assurances being made by requesting states as to how an

\footnotetext{
${ }^{404}$ Law Commission, above n 2, at 197.

${ }^{405}$ At 188.

${ }^{406}$ Law Commission, above n 10, at 43.

${ }^{407}$ Law Commission, above $\mathrm{n} 2$, at 13.

${ }^{408}$ At 18.

${ }^{409}$ Law Commission, above n 10, at 40-42.
} 
individual will be treated on return. The Law Commission, therefore, recommended that the death penalty and, where expressly provided for in a treaty, citizenship and extraterritorial grounds be dealt with by the Minister. This is because the death penalty ground often necessitates assurances and monitoring which is best undertaken by a government department. ${ }^{410}$ This seems counterintuitive when under the proposals the Attorney-General assisted by the Crown Law Office would be liaising with requesting states to seek such assurances not the courts or the Minister of Justice. Furthermore, grounds proposed to be dealt with by the courts, such as the risk of torture and breach of fair trial rights, will also often require undertakings being made by requesting countries including monitoring arrangements.

\section{Further Codification of the Practice of Seeking Diplomatic Assurances}

Currently, under the Extradition Act 1999, the Minister of Justice may seek any undertakings from a requesting country for the purposes of determining whether to surrender an individual for extradition. ${ }^{411}$ The draft Bill goes much further in its codification of this practice. The Central Authority is expressly given the "entitlement" to seek assurances from requesting countries in relation to any of the grounds for refusal dealt with by the courts. The rationale behind this is that, as the practice of seeking assurances is diplomatic in nature, therefore this practice should be conducted between government representatives. In reality, seeking assurances would be conducted with the assistance of MFAT. ${ }^{412}$

In deciding whether to commence extradition proceedings, the Central Authority has discretion to take into account any concerns about the reliability of information or assurances provided by the requesting country. ${ }^{413}$ At the preliminary stage of the proceedings, the District Court can make directions at an "issues conference" that the assessment of the criteria for extradition and consideration of any grounds for refusing extradition should be dealt with at separate hearings. When making these directions, the Court must take into account the possibility that the Central Authority may intend to seek assurances from the requesting country in relation to one or more of the grounds for refusal. This is to recognise that, in some instances, it may not be appropriate to obtain diplomatic assurances relating to a ground for refusing extradition until the Court has determined whether the criteria for extradition have been satisfied. This is because the

\footnotetext{
${ }^{410}$ Law Commission, above $\mathrm{n} 2$, at 39-40.

${ }^{411}$ Extradition Act 1999, s 30(6).

${ }^{412}$ Law Commission, above $\mathrm{n} 2$, at 191.

${ }^{413}$ At 198. See clause 25(3) of the Law Commission's draft Extradition Bill.
} 
practice of obtaining assurances is resource intensive and that it is preferable for assurances to be given as close as possible to the time when the extradition will occur to reduce the possibility of unforeseen circumstances undermining such commitments. ${ }^{414}$

\section{$D$ The Law Commission's Approach to the Role of Bilateral Treaties}

The Law Commission's approach to bilateral extradition treaties is premised on the view that bilateral treaties should only be permitted to supplement the provisions of its proposed legislation, and only in key areas such as altering procedure and providing for additional extradition offences. ${ }^{415}$ In order to understand how the Commission's approach would change the position under the current legislation, it is necessary to outline how the Extradition Act 1999 currently interacts with bilateral treaties.

\section{Section 11 of the Extradition Act 1999}

The Extradition Act 1999 provides that its provisions must be construed to give effect to an extradition treaty where one is in force between New Zealand and an extradition country. ${ }^{416}$ However, extradition treaties agreed after the Act came into force may not be construed to override the following provisions of the Act:

(1) the mandatory restrictions on surrender in section 7 of the Act;

(2) the requirement to show a prima facie case for eligibility for surrender; ${ }^{417}$

(3) the prohibition preventing an individual from adducing evidence to contradict an allegation that the individual has committed an extradition offence; ${ }^{418}$

(4) the mandatory ground for refusing surrender where there are substantial grounds for believing that an individual would be in danger of being subject to an act of torture in the requesting country; ${ }^{419}$

\footnotetext{
${ }^{414}$ At $200-201$.

${ }^{415}$ Law Commission, above n 10, at 22.

${ }^{416}$ Extradition Act 1999, s 11(1).

${ }^{417}$ Section 24(2)(d).

${ }^{418}$ Section 45(5).

${ }^{419}$ Section 30(2)(b).
} 
(5) the discretionary ground for refusing surrender if it appears that the individual may be subject to the death penalty on surrender, or ${ }^{420}$

(6) any provision conferring a particular function or power on the Minister or a court.

The reason for not imposing these restrictions on extradition treaties entered into by New Zealand before the 1999 Act $^{421}$ came into force was because the Act had made changes to the grounds for refusing surrender that were often inconsistent with the pre-existing treaties. $^{422}$ It should be noted that article 27 of the Vienna Convention on the Law of Treaties (VCLT) expressly prohibits a party to a treaty from invoking its domestic law as justification for not complying with a treaty.

Most notably missing from the restrictions in the 1999 Act is the discretion to refuse surrender where an individual would not receive a fair trial. This is not possible while the ground is not specified under the Act and can only be invoked under the discretionary ground of "any other reason" for refusing surrender. ${ }^{423}$ This may mean that in circumstances where there is a bilateral extradition treaty with a requesting country, which is silent with respect to fair trial rights, the obligation to extradite an individual under the treaty would raise the threshold on which to determine the requisite breach of fair trial rights warranting refusal to surrender an individual for extradition. As argued by Crown Law in its advice to the Minister of Justice regarding the extradition of Kyung Yup $\mathrm{Kim}^{424}$, the obligation to extradite under a bilateral treaty could warrant determining the likelihood of an individual receiving a fair trial on return under a higher threshold than the "reasonable accordance" test applied by the Minister. ${ }^{425}$ Whether the obligation to extradite under an extradition treaty would make any real difference to the threshold risk requirement employed under the Court of Appeal's "real risk of a departure" ${ }^{\$ 26}$ test seems questionable.

\footnotetext{
420 Section 30(3)(a).

${ }^{421}$ Section 11(2) does not apply to pre-existing treaties because of s 11(3) and s 105.

${ }^{422}$ Law Commission, above n 10, at 29.

${ }^{423}$ Extradition Act 1999, s 30(3)(e).

${ }^{424}$ Kyung Yup Kim v Minister of Justice [first judicial review], above n 91, at [109].

425 Joanna Judge "Modernising New Zealand's Extradition Law: A Critique of the Law Commission's Proposal" (LLB (Hons) Dissertation, Victoria University of Wellington, 2016) at 32.

${ }^{426}$ Kyung Yup Kim v Minister of Justice, above n 94, at [179].
} 


\section{The Law Commission's recommendation in respect of bilateral extradition treaties}

The Law Commission recommends that New Zealand retain its current extradition system which allows all countries to seek extradition from New Zealand without requiring a treaty to be in force in order for a country to obtain extradition of an individual from New Zealand. $^{427}$ The Law Commission's primary concern is the impediments to the extradition process created by the current legislation as a result of the Extradition Act's requirement that the Act be construed to give effect to a bilateral extradition treaty in force with a requesting country. This concern is primarily focused on extradition treaties entered into prior to the 1999 Act coming into force as treaties entered into after this time are restricted in their capacity to be construed differently from the Act in any case. The vast majority of New Zealand's bilateral extradition treaties were agreed before the 1999 Act at a time when human rights were not recognised to the extent they are now and the terminologies used in those treaties are no longer used domestically in New Zealand. In short, these extradition treaties are out of date and out of step with modern international human rights law. Accordingly, the Commission recommends that the interpretive provision as outlined in s 11 of the Extradition Act 1999 not be retained and that it be replaced with a provision that would specifically identify the following requirements, procedures and grounds for refusal that must only be interpreted in accordance with the proposed legislation: ${ }^{428}$

(1) The definition of an extradition offence. ${ }^{429}$

(2) The mandatory grounds for the court to refuse extradition. ${ }^{430}$

(3) The mandatory and discretionary grounds for the Minister to refuse extradition. ${ }^{431}$

(4) The procedure for making an extradition request. ${ }^{432}$

(5) The procedure following an arrest under a provisional arrest warrant. ${ }^{433}$

\footnotetext{
${ }^{427}$ Law Commission, above n 2, at 20.

${ }^{428}$ At 21.

${ }^{429}$ Law Commission's draft Extradition Bill, cl 7.

${ }^{430}$ Clause 20.

${ }^{431}$ Clause 21.

${ }^{432}$ Clause 23.

${ }^{433}$ Clause 72.
} 
(6) New Zealand's ability to make a request for extradition of an individual from a foreign country. ${ }^{434}$

(7) The provision that persons extradited to New Zealand, or who are transported through New Zealand for the purpose of extradition to another country, do not have to hold an immigration visa. ${ }^{435}$

\section{The Law Commission's approach to bilateral extradition treaties}

The Law Commission is backward rather than forward looking in its view of the role bilateral extradition treaties should have in New Zealand's extradition system. Most of New Zealand's 45 bilateral extradition treaties were entered into between 80 and 140 years ago. Forty one of those treaties were negotiated by Great Britain on behalf of the British Empire between 1870 and 1935. ${ }^{436}$ The Law Commission's concern is centred on how New Zealand's current extradition treaties have become out dated rather than in what way bilateral treaties will play a role in New Zealand's extradition system in the future. In the Law Commission's view: ${ }^{437}$

[T] he object of the bilateral extradition treaties, as stated in the treaties themselves, is to facilitate extradition between the state parties by creating a duty to extradite in certain circumstances.

This view oversimplifies the objective(s) of extradition treaties. Arguably, bilateral extradition treaties have always had multiple objectives. Their objective is not only to facilitate extradition, but also to protect state sovereignty and the individuals sought for extradition from being treated unfairly as a result of extradition. Even the oldest imperial extradition treaties to which New Zealand is a party, had as one of their objectives to protect an individual sought for extradition from double jeopardy. ${ }^{438}$ In reality, as international human rights law has developed, the recognised protections for an individual facing extradition have grown, outpacing the grounds for refusing extradition under the older treaties. If a purpose of the early extradition treaties was not to protect an individual subject to an extradition request, then surely the more recent extradition treaties to which New Zealand is a party at present have this as one of their purposes

\footnotetext{
${ }^{434}$ Clause 101.

${ }^{435}$ Clause 114.

${ }^{436}$ Law Commission, above n 10, at 22-23.

${ }^{437}$ At 26.

${ }^{438}$ At 24.
} 
since international human rights law has evolved and become expressed in multilateral human rights instruments. Particularly in light of the rule of interpretation contained in the VCLT that when interpreting a treaty in light of its context, the context of the treaty should include "any relevant rules of international law applicable in the relations between the parties". 439

The Law Commission considers that protection for individuals subject to extradition requests is best served through providing for protections in domestic statute than relying on extradition treaties. In support of this view, the Commission cites the following provision found in the New Zealand's bilateral extradition treaties with Fiji and the United States: ${ }^{440}$

The determination that extradition based upon the request therefore should or should not be granted shall be made in accordance with the laws of the requested Party and the person whose extradition is sought shall have the right to use such remedies and recourses as are provided by such law.

The Law Commission neglects to point out that New Zealand's most recent bilateral extradition treaties with Hong Kong (1998) and the Republic of Korea (South Korea) (2002) do not include a similar provision.

The problem with the Law Commission's approach is that it fails to recognise that the only way a foreign state can be unequivocally bound to New Zealand, in accordance with international law, is by way of a treaty. Domestic legislation can never fulfil this role or effectively be a substitute for a legally binding treaty, particularly when the most recent human rights issues relating to extradition have drawn the focus away from whether an individual should be surrendered for extradition to whether an individual will be protected after an individual is extradited to another country. Moreover, New Zealand's domestic legislation is unable to supplant the domestic legislation in a requesting state like China, unlike a binding treaty which could potentially modify China's domestic law. Furthermore, the Law Commission's narrow view as to the objective or purpose of bilateral extradition treaties means that the Commission considers that the only possible material breach under an extradition treaty that can occur is one under a provision of an extradition treaty that is essential to the accomplishment of the objective to facilitate

\footnotetext{
${ }^{439}$ VCLT, art 31(2)(c).

440 Agreement on Extradition between the Government of New Zealand and the Government of the Republic of Fiji [1992] NZTS 3 (signed 21 March 1992, entered into force 14 April 1992), art 9 and Treaty on Extradition between New Zealand and the United States of America [1970] NZTS 7 (signed 12 January 1970, entered into force 8 December 1970), art 9.
} 
extradition rather than protect an individual subject to an extradition request. ${ }^{441}$ The Law Commission's proscriptive approach to the role of extradition treaties is skewed by the Commission's preoccupation with the role bilateral extradition treaties played in the past and fails to form a vision for the role extradition treaties are likely to assume in the future. There is no vision for how New Zealand's domestic legislation could supplement the role of extradition treaties in protecting an individual in a requesting state after being extradited. For instance, New Zealand's domestic legislation could expressly allow the courts and Minister to consider any human rights guarantees contained in the provisions of an extradition treaty when considering whether there are grounds for refusing extradition.

E The Essential Role of Bilateral Extradition Treaties in New Zealand's Extradition Relationships with Countries such as China

The Law Commission's view that the proposed legislation will be a 'baseline' which bilateral extradition treaties will merely supplement fails to grasp the essential role bilateral treaties could play in terms of New Zealand's extradition relationships with countries such as China in future. Domestic extradition law coupled with an ever increasing reliance on diplomatic assurances to circumvent breaches of international human rights law will never be an adequate substitute for the idiosyncratic and binding structures that constitute bilateral extradition treaties. Treaty law will never merely supplement domestic legislation. In reality, New Zealand's domestic extradition law is merely a substructure on which bilateral extradition treaties will be constructed. New Zealand's domestic extradition law and the Law Commission's proposals for reforming the legislation that underpins that law should be viewed as constituting only a temporary means by which to facilitate extradition to countries in circumstances where serious human rights concerns arise. New Zealand's domestic extradition law should be viewed as constituting a substructure which will one day facilitate and supplement more structured extradition relationships governed by bilateral extradition treaties. The Law Commission's recommendations for reform should by no means be viewed as constituting the quintessential model for governing New Zealand's extradition relationships with countries such as China going forward.

The next chapter will consider what form a bilateral extradition treaty with China should encapsulate and examine how such a treaty would bring a more structured approach to China and New Zealand's extradition relationship by way of a more well-defined and

${ }^{441}$ Law Commission, above n 10, at 26. 
binding extradition process that would ultimately transcend the disparate aspects of both countries' criminal justice systems. 


\section{Towards Concluding an Extradition Treaty with China}

In April 2016, the issue of economic fugitives residing in New Zealand sought by China for extradition to face prosecution for fraud and embezzlement was raised during a discussion between then Prime Minister John Key and Chinese Premier Li Keqiang in Beijing. Mr Key stated at the time that he was not opposed to a formal treaty being agreed with China for serious cases and people would not face torture or the death penalty: "I think it's possible - we're certainly not opposed". ${ }^{442}$ In March 2017, the government of Australia decided to withdraw an extradition treaty between Australia and China from the Australian Senate when it became clear that there was insufficient support to ratify the treaty. This was due to members of the Australian Parliament on both sides of the political spectrum being opposed to Australia extraditing individuals to China. This was because of perceived human rights inadequacies in China's judicial system. ${ }^{443}$ By November 2017, shortly after the general election, the newly elected Prime Minister, Jacinda Ardern, stated that an extradition treaty with China was "not something on my agenda". ${ }^{444}$ However, newly appointed Minister of Foreign Affairs and Trade, Winston Peters, speaking about his meeting with his Chinese counterpart Chinese Foreign Minister Wang Xi at the APEC leaders' summit in 2017, stated: ${ }^{445}$

You've got to remember that when the president [Xi Jinping] came to power the first priority he had was to end corruption in China, and he's trying to end it from people who are behaving corruptly in China and seeking domicile and safe haven in New Zealand. I think it's fair enough for us to cooperate with them, providing of course that they don't end up being executed as a consequence.

\section{A Analysis of Extradition Treaties between China and other Developed Nations}

This section will endeavour to identify the challenges New Zealand will face when it negotiates and concludes its own extradition treaty with China by evaluating the form in which extradition treaties between China and other developed countries have taken, before finally turning to consider what should be included in an extradition treaty between New Zealand and China.

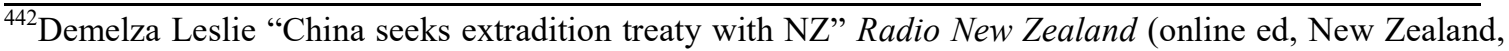
19 April 2016).

443 Stephen Dziedzic, "Australia-China extradition treaty pulled by Federal Government after backbench rebellion" ABC News (online ed, Australia, 28 March 2017).

444 Sam Sachdeva, "Peters pulls his punches on China" (13 November 2017) Newsroom $<$ www.newsroom.co.nz>.

445 Sachdeva, above n 445.
} 
China currently has 39 bilateral extradition treaties with other states although not all of these treaties are presently in force ${ }^{446}$ as not all of the treaties have been ratified by both parties. This section will focus on extradition treaties signed between China and Western developed states, which at the time of writing, are predominately with developed countries in Western Europe - Spain, Portugal, France and Italy - all of which have been ratified by both parties and therefore presently in force. China has also signed an extradition treaty with Australia which so far has not been ratified by the Australian federal government.

\section{Extradition Treaty between the People's Republic of China and the Kingdom of Spain}

Spain was the first Western developed country to sign a bilateral extradition treaty with China. ${ }^{447}$ The treaty was signed in November 2005 and ratified by the National People's Congress in April 2006. ${ }^{448}$ The treaty came into force in April $2007 .^{449}$ The treaty's only exceptional quality is how unremarkable it is. It follows the conventional format of most extradition treaties ${ }^{450}$, similar to the United Nations Model Treaty on Extradition. ${ }^{451}$ The mandatory ground for refusal on the basis that the offence for which extradition is sought is a "political offence" excludes terrorist offences and certain offences not considered to be political offences under any international convention to which China and Spain are parties. ${ }^{452}$ It is mandatory to refuse extradition when an individual sought for extradition may be sentenced to death in respect of the offence for which extradition is sought, unless the requesting party gives adequate assurance that the requesting party will not impose the death penalty on the individual, or will not execute the individual if the death penalty

\footnotetext{
446 中央纪委国际合作局 "中国对外缔结的引渡条约清单” (2017年12月8日) 全国人民代表大会 <www.npc.gov.cn>. (translation: International Cooperation Bureau of the Central Commission for Discipline Inspection "List of extradition treaties concluded by China" (8 December 2017) The National People's Congress of the People's Republic of China <www.npc.gov.cn>).

447 Law Press China "China's judicial assistance” (21 July 2015) The Supreme People's Court of the People's Republic of China $<$ www.english.court.gov.cn>.

448 Xinhau "China ratifies extradition treaty with China" (29 April 2006) The State Council of the People's Republic of China $<$ www.english.gov.cn>.

449 Thomas Eder, Bertram Lang, Moritz Rudolf “China's Global Law Enforcement Drive: The need for a European response" (18 January 2017) Merics: Mercator Institute for China Studies <www.merics.org > at 8.

450 中国人大网“中华人民共和国和西班牙王国引渡条约”全国人民代表大会 <www.npc.gov.cn>. (translation: China National People's University “Extradition Treaty between the People's Republic of China and the Kingdom of Spain" The National People's Congress of the People's Republic of China $<$ www.npc.gov.cn>).

${ }^{451}$ Model Treaty on Extradition GA Res 45/116 A/Res/45/116 (1990).

${ }^{452}$ Extradition Treaty between the People's Republic of China and the Kingdom of Spain, above $n$ 451, art $3(1)$.
} 
has already been imposed. ${ }^{453}$ It is mandatory to refuse extradition if the individual sought for extradition is a national of the requested party. ${ }^{454}$ However, if extradition is refused on the basis of nationality, the requested party shall refer the case to its competent authorities for the purpose of instituting criminal proceedings under its domestic law at the request of the requesting party. ${ }^{455}$ There are no grounds for refusal on the basis that there is a risk of an extradited individual being subject to torture, or a risk of the individual not receiving a fair trial, after extradition to the requesting party.

\section{Treaty between the Portuguese Republic and the People's Republic of China on Extradition}

An extradition treaty between Portugal and China was signed in January 2007 and ratified by the National People's Congress in October $2008 .{ }^{456}$ The treaty came into force in July 2009. ${ }^{457}$ The extradition treaty between Portugal and China is almost identical to the treaty between Spain and China. They both follow the same format consisting of 21 articles with the same headings and articles in exactly the same order. ${ }^{458}$ The most striking difference is that the mandatory ground for rejecting a request for extradition on the basis that the individual sought for extradition would be subject to the death penalty is missing from the treaty. Instead the following ground for refusal appears in its place: ${ }^{459}$

[T]he execution of the request would impair sovereignty, security, public order or other essential public interests of the Requested Party, or would be contrary to the fundamental principles of its internal law.

This rather ambiguous open ended ground for refusing extradition would appear to allow Portugal to reject an extradition request on the basis of any fundamental principles of its domestic law, including its obligations under international human rights law.

\footnotetext{
453 Article 3(8).

454 Article 3(4).

${ }^{455}$ Article 5.

456 "Decision of the Standing Committee of the National People's Congress on Ratifying the Extradition Treaty between the People's Republic of China and the Republic of Portugal" (28 October 2008) Law Info China $<$ www.lawinfochina.com $>$.

${ }^{457}$ Eder, Lang, and Rudolf, above n 420, at 8.

458 Treaty between the Portuguese Republic and the People's Republic of China on Extradition, PortugalChina (signed January 2007, entered into force July 2009). An English translation of the treaty is available on the Portuguese Parliament's website <www.parlamento.pt $>$.

${ }^{459}$ Article 3.1(h).
} 
Another difference is that terrorist offences are not expressly excluded from the mandatory "political offence" ground for refusing extradition. Instead the treaty provides that offences that are not regarded as political offences under the domestic law of the requested party or under any international treaty, convention or agreement to which both states are parties are not to be considered to be political offences. ${ }^{460}$

\section{Extradition Treaty between the French Republic and the People's Republic of China}

The extradition treaty between China and France was signed in September $2007^{461}$ and ratified by the National People's Congress in $2008 .{ }^{462}$ It came into force in July $2015 .^{463}$ The treaty consists of 23 articles. ${ }^{464}$ Although the format of the treaty is slightly different from the treaties with Spain and Portugal the treaty is really very similar. As with the treaties with Spain and Portugal, it is mandatory to refuse a request if the individual sought for extradition is a national of the requested party. ${ }^{465}$ Similar to the treaty with Spain, there is a mandatory ground for refusing extradition if the individual sought will be sentenced to death unless sufficient assurances are provided by the requesting party that the death penalty will not be imposed. ${ }^{466}$ There is no provision for an exception with respect to terrorist offences under the mandatory "political offence" ground for refusing extradition. $^{467}$

\section{Extradition Treaty between the People's Republic of China and the Italian Republic}

The extradition treaty with Italy was signed in October 2010 and ratified by the National People's Congress in December 2011. ${ }^{468}$ The treaty came into force in December 2015. ${ }^{469}$ The treaty consists of 21 articles following an identical format to the treaties with Spain

\footnotetext{
460 Article 3.2 .

${ }^{461}$ Qin Jize "Treaty on extradition signed” China Daily (online ed, China, 7 September 2007).

462 Chen Heying "Sino-French extradition treaty begins operating" Global Times (online ed, China, 18 July 2018).

${ }^{463}$ Eder, Lang, Rudolf, above n 450, at 8.

${ }^{464}$ 中国人大网“中华人民共和国和法兰西共和国引渡条约”全国人民代表大会 $<$ www.npc.gov.cn>. (translation: China National People's University “Extradition Treaty between the People's Republic of China and the French Republic" The National People's Congress of the People's Republic of China $<$ www.npc.gov.cn>).

465 Article 4.

466 Article 3(7).

467 Article 3(1).

468 Xinhua "China ratifies extradition treaty with Italy" (22 July 2015) The Supreme People's Court of the People's Republic of China <www.english.court.gov.cn>.

${ }^{469}$ Eder, Lang, Rudolf, above n 450, at 8.
} 
and Portugal. ${ }^{470}$ Similar to those treaties, terrorist offences are expressly excluded from the mandatory "political offence" ground for refusing extradition as the treaty provides that terrorist offences, and offences designated by international treaties, conventions and agreements to which both states are parties, cannot be considered crimes of a political nature. ${ }^{471}$ The most distinctive characteristic of this treaty, when compared to the other treaties we have considered so far, is a mandatory ground for refusing extradition where there are substantial grounds for believing that the individual sought for extradition has suffered or may be subject to torture, or other cruel, inhuman or degrading treatment or punishment for the offence against which the request for extradition is directed. ${ }^{472}$ Furthermore, there is a mandatory ground for refusing extradition, similar to the treaty with Portugal, in circumstances where granting the extradition request may damage the sovereignty, security, public order or other material interests of the requested party, or the consequences of granting the request would be contrary to the fundamental principles of the requested party's domestic law, including the imposition of types of penalties prohibited by the law of the requested party. ${ }^{473}$

\section{Treaty on Extradition between Australia and the People's Republic of China}

Australia signed an extradition treaty with China in September 2007. ${ }^{474}$ The treaty has not been ratified by the federal government of Australia so the treaty is not in force. No extraditions have taken place from Australia to China. The treaty consists of 23 articles and although it follows a fairly standard format it does not follow the exact same format of any of the treaties considered above. ${ }^{475}$ The format of the treaty is most similar to the treaty with France although the ordering of the articles is dissimilar and some articles appearing in the treaty with France are not present in the treaty with Australia. This similarity may be due to the treaties with France and Australia being signed at the same time. Unlike the other treaties considered above, both the treaties with France and Australia have an article providing that the treaty shall not affect any rights or obligations

\footnotetext{
$\overline{470}$ 中国人大网 “中华人民共和国和意大利共和国引渡条约” 全国人民代表大会 <www.npc.gov.cn $>$. (translation: China National People's University "Extradition Treaty between the People's Republic of China and the Italian Republic" The National People's Congress of the People's Republic of China $<$ www.npc.gov.cn>).

${ }^{471}$ Article 3(1).

${ }^{472}$ Article 3(6).

${ }^{473}$ Article 3(7).

474 “China Extradition Treaty" (28 March 2017) Australian Government Department of Foreign Affairs and Trade $<$ www.dfat.gov.au $>$.

475 Treaty on Extradition between Australia and the People's Republic of China, Australia-China (signed 6 September 2007, not yet in force). The English translation is available on the Parliament of Australia's website $<$ www.aph.gov.au $>$.
} 
under any multilateral conventions. ${ }^{476}$ The right to refuse extradition of a party's nationals is a discretionary ground for refusing extradition and like the other treaties considered above there is an obligation on a party which refuses extradition on the basis of nationality to submit the case to its competent authorities for the purpose of instituting criminal proceedings. ${ }^{477}$ Terrorist offences are not excluded from the mandatory "political offence" ground for refusing extradition. ${ }^{478}$ The mandatory discrimination ground for refusal includes "language" and "personal status" as bases for discrimination as well as "race, sex, religion, nationality and political opinion". ${ }^{479}$ Extradition must be refused if in accordance with the law of the requesting party, the individual sought may be sentenced to death for the offence for which extradition is requested, "unless the requesting party undertakes that the death penalty will not be imposed or, if imposed, will not be carried out". ${ }^{480}$ An extradition request must be refused if the requested party has substantial grounds for believing the individual sought for extradition has been or will be subjected to torture or other cruel, inhuman or humiliating treatment or punishment in the requesting party. ${ }^{481}$

The extradition treaty between Australia and China was withdrawn from a vote on its ratification in March 2017 when it became clear that the government would be unable to obtain the necessary support in Parliament to ratify the treaty in both the House of Representatives and the Senate. ${ }^{482}$ It is only possible for China to extradite an individual from Australia if it is declared an 'extradition country' by way of regulation. Although there are some countries with non-treaty extradition agreements declaring them to be extradition countries by regulation, an extradition treaty with Australia would ensure China is able to extradite individuals from Australia. At present, China can theoretically seek extradition of individuals from Australia for certain offending under Conventions such as UNCAC, but at the time of writing UNCAC had never been utilised by either country to make extradition requests. ${ }^{483}$

\footnotetext{
${ }^{476}$ Article 21 of the treaty with Australia and article 20 of the treaty with France.

477 Treaty on Extradition between Australia and the People's Republic of China, above n 476, art 5.

478 Article 3(a).

${ }^{479}$ Article 3(b).

${ }^{480}$ Article 3(f).

481 Article 3(g).

482 Dziedzic, above n 444.

${ }^{483}$ Stobbs, above n 279, at 45-47.
} 
The Joint Standing Committee on Treaties (JSCOT) while recommending that the Australian Parliament ratify the treaty noted that there were "serious concerns" raised by the submissions made to the Committee with respect to: ${ }^{484}$

1. the right to a fair trial;

2. possible imposition of the death penalty;

3. evidential standards;

4. protection from torture, cruel, inhuman, humiliating treatment or punishment;

5. omission of the words 'unjust or oppressive' from Article 4(c);

6. extradition of minors; and

7. monitoring of individuals extradited to China.

(a) Right to a fair trial

JSCOT noted the concerns raised with respect to China's criminal justice system, primarily its lack of judicial independence and the prevalence of forced confessions extracted through torture and ill-treatment. The Attorney-General's Department (AGD) submitted that the general discretions under the Extradition Act 1988 (Cth) for the Minister for Justice to refuse extradition would allow the Minister to consider the extent to which an individual would receive a fair trial. This would involve the negotiation of assurances on a case-by-case basis. ${ }^{485}$ The Law Council of Australia (LCA) submitted that such a process would be unsatisfactory primarily because it provided inadequate protection of fair trial rights "as it relies on the discretion of the decision makers in each country and the process could be "influenced by a wide range of factors", ${ }^{486}$

(b) Imposition of the death penalty

The LCA noted that an undertaking not to carry out the death penalty is legally unenforceable and that the treaty did not contain a provision for consequences in the event of non-compliance. The only consequence for non-compliance would be the Attorney-General's discretion to refuse future requests. The AGD emphasised the critical importance of government-to-government undertakings and the serious impact breach of an undertaking would have on a country's international crime cooperation relationship with other countries but also the broader bilateral relationship. The AGD also pointed out

\footnotetext{
$\overline{484}$ Joint Standing Committee on Treaties "Report 167 Nuclear Cooperation-Ukraine; Extradition-China" (December 2016) Parliament of Australia <www.aph.gov.au> at 22.

485 At $22-24$.

${ }^{486}$ At 25.
} 
that Australia already has extradition treaties with a number of other countries which retain the death penalty. ${ }^{487}$

(c) Torture, cruel, inhuman, humiliating treatment or punishment

JSCOT noted that there was concern regarding how the government would determine what should constitute 'substantial grounds' for believing an individual has been or will be subject to torture or other cruel, inhuman or humiliating treatment or punishment. The AGD emphasised that there would be extensive scrutiny as to the circumstances prevailing in the requesting country and assurances sought in respect of each individual case along with an individual's ability to seek judicial review of decisions to surrender individuals for extradition, which would provide individuals with the opportunity to present relevant information where there is a concern an individual will be subject to torture or ill-treatment after surrender. ${ }^{488}$

(d) Omitting the words 'unjust and oppressive'

The Extradition (Commonwealth Countries) Regulations, relating to 50 Commonwealth jurisdictions, not only include humanitarian considerations such as age, health and personal circumstances as discretionary grounds for refusing surrender but also include the words 'unjust and oppressive'. Ten bilateral extradition treaties with Australia also include these words. The AGD was unable to explain why the words had not been included in the treaty and emphasised that the discretionary grounds in the treaty and the Extradition Act 1988 (Cth) would be adequate to ensure Australia meets its international obligations. $^{489}$

(e) No evidence standard

There was concern that the treaty only provided a 'no evidence' threshold for extradition, which would only require China to provide a statement as to the conduct alleged against an individual sought for extradition. The LCA would prefer that Australia return to a standard that would allow the ability for evidence to be tested and challenged before a decision to extradite an individual is made. ${ }^{490}$

$\overline{487}$ Indonesia, India, Malaysia, the United Arab Emirates, the United States of America, Vietnam, Brazil, Chile, Israel and the Republic of Korea.

488 Joint Standing Committee on Treaties, above n 485, at 28-29.

489 At $29-30$.

${ }^{490}$ At $30-31$. 


\section{(f) Extradition of minors}

There was also concern raised by the LCA regarding there being no mandatory exclusion against extraditing minors provided for in the treaty. The AGD pointed out that although there is no specific age limits relating to age, the age of an individual is taken into consideration in assessing an individual's circumstances and that both Australia's and China's obligations under the Convention on the Rights of the Child would ensure children are protected. ${ }^{491}$

(g) Monitoring of individuals extradited from Australia

JSCOT noted that it had previously expressed concern regarding monitoring of individuals after extradition and had made recommendations to successive governments. JSCOT noted that the obligation under the treaty for the requested party to be provided with information relating to the proceedings and sentence along with consular assistance by the Department of Foreign Affairs and Trade for Australian citizens and permanent residents was "not enough to allay concerns". ${ }^{9}$. The AGD again emphasised the government's ability to seek assurances in cases where there were concerns in respect of a particular individual: "one of the things that we might have built into the agreement to extradite... may well be a requirement that we have access to that person..."

\section{B The Need for an Unconventional Extradition Treaty with China}

When considering the treaties signed between China and other Western countries so far, as outlined above, it is argued here that an extradition treaty following the traditional model will not be sufficient to provide adequate assurance that individuals will be protected from human rights abuses when extradited from New Zealand to China. This is because the orthodox extradition treaty model does nothing to remove a states' reliance on diplomatic assurances to protect against human rights concerns. A legally binding treaty with China must include specific fair trial guarantees and a monitoring regime to address the human rights issues surrounding extradition of individuals to China in reliance on non-binding diplomatic assurances. Depriving an individual of the minimum guarantees contained in article 14 of the ICCPR is included as a mandatory ground for

\footnotetext{
491 At 31-32.

492 At 33 .

${ }^{493}$ At 33 .
} 
refusing extradition in the United Nations Model Treaty on Extradition. ${ }^{494}$ However, more specificity is required than provided for in the draft Model Treaty to ensure that the specific risks related to extraditing an individual to China are addressed not only as a ground for refusing extradition, but also as a means by which to ensure that protection continues after extradition of an individual to China. Monitoring provisions must also be incorporated into the agreement to ensure compliance with the treaty.

Of course, the question remains as to what added protection if any a treaty would provide in the event that China were to breach a condition provided for under a binding treaty rather than a non-binding diplomatic assurance. Furthermore, none of the Western developed countries which have concluded extradition treaties with China ${ }^{495}$ have explicitly included minimum guarantees under the ICCPR as a mandatory ground for refusing extradition. China has not ratified the ICCPR nor made a declaration under article 41 allowing the Human Rights Committee to receive complaints from state parties who have made a declaration under that article with respect to violations of the ICCPR. In the event that China was to breach the ICCPR, there is no international recourse. China has ratified CAT; however, it made reservations declining to recognise the competence of the Committee against Torture to investigate and report under article 20; and rejected the dispute resolution mechanism and jurisdiction of the ICJ under article 30. China has not made a declaration under article 22 of CAT which provides for complaints to be made by individuals to the Committee. Nor has China signed or ratified the Optional Protocol. Accordingly, there is no recourse to international institutions in respect of individual complainants of torture perpetrated by Chinese state law enforcement agencies or disputes relating to torture between China and other state parties to CAT. Furthermore, China is not a party to any of the Optional Protocols of the VCLT meaning that the ICJ would not have automatic jurisdiction over a dispute arising out of the interpretation or application of the VCLT in relation to a bilateral extradition treaty between New Zealand and China.

Due to China's strong ideological position with regards to protecting its state sovereignty and self-determination, it seems unlikely that China would agree to the incorporation of a compulsory dispute settlement mechanism into an extradition treaty with New Zealand or consent to referral of a dispute to the ICJ in the event of a dispute over the interpretation of the extradition treaty. However, New Zealand could terminate or suspend the operation of the treaty in the event of a "material breach" consisting of a "violation of a provision

\footnotetext{
${ }^{494}$ Model Treaty on Extradition GA Res 45/116 A/Res/45/116 (1990).

${ }^{495}$ Spain, Portugal, France and Italy.
} 
essential to the accomplishment of the object or purpose of the treaty". ${ }^{496}$ If the breach has caused harm to New Zealand or its nationals, New Zealand may have the right to take countermeasures or make an international claim for compensation or relief. ${ }^{497}$ A state is initially most likely to resort to countermeasures in response to a breach of a treaty obligation. $^{498}$ Countermeasures are essentially a state's non-performance of certain international obligations it owes to the state it considers has harmed it. Such countermeasures must be proportionate and are initiated solely for the purpose of compelling a state to cease breaching a treaty and make full reparation. ${ }^{499}$ The obvious countermeasure that New Zealand could implement in the event that China was to breach its obligations under an extradition treaty would be for New Zealand to suspend the extradition of all individuals sought for extradition by China until the breach is remedied or the individual concerned is returned to New Zealand. Crucially, suspension would be a far more immediate consequence of non-compliance than the political consequences of breaching diplomatic assurances could ever provide. Currently a potential response to a breach of a diplomatic assurance would be New Zealand's refusal of a hypothetical and unrelated request for extradition by China at an unknown time in the future. A treaty would provide New Zealand with an immediate response to a breach of its terms in contrast to the piecemeal and somewhat delayed response available under the current ad hoc system.

\section{Proposals for an Extradition Treaty between New Zealand and China}

The following proposals for an extradition treaty between New Zealand and China may seem like a radical departure from the conventional model that extradition treaties have commonly come to compose, but such new formulations naturally arise from the confluence of extradition law and developments in international human rights law. This merging of two branches of international law makes it clear that: ${ }^{500}$

$[t]$ he enforcement of international criminal law is better served by an extradition law that expressly accommodates the interests of human rights than by one that fails to acknowledge the extent to which human rights law has reshaped this branch of international cooperation.

\footnotetext{
496 Vienna Convention on the Law of Treaties 1155 UNTS 331 (opened for signature 29 April 1970, entered into force 27 January 1980) [VCLT], art 60.

497 Aust, above n 229, at 293.

${ }^{498}$ At 362 .

499 At 363-365. See Gabclkovo-Nagymaros Project (Hungary v Slovakia) (Judgment) [1997] ICJ Rep 7.

500 John Dugard and Christine van den Wyngaert "Reconciling Extradition with Human Rights" (1998) 92 Am J Intl L 187 at 212.
} 
The natural consequence of the ECtHR's decision in Othman (Abu Qatada) $v$ United Kingdom and what followed closely on the heels of the Court's decision was the formulation of a legally binding agreement between the United Kingdom and Jordan that provided for fair trial guarantees. It would not be a huge leap in the development of extradition law for bilateral extradition treaties between Western developed countries such as New Zealand and countries such as China to not only contain fair trial guarantees, but to also contain the monitoring mechanisms necessary to ensure that the agreements are adhered to.

The Othman decision forced the British Home Secretary to conclude a 'mutual legal assistance agreement' between the United Kingdom and Jordan, which entered into force in June 2013. ${ }^{501}$ The treaty ${ }^{502}$ specifies a number of fair trial guarantees for deportees and prohibits the use of evidence obtained by use of torture at trial. ${ }^{503}$ A Judge of the Special Immigration Appeals Commission, Irwin LJ reportedly stated that ratification of the treaty alone would not be enough on its own. It would only be after the treaty's entry into force that it would override the ruling of the Jordanian courts with respect to admission of evidence obtained by torture. Accordingly, it was not until after the treaty was formally approved by Jordan's King Abdullah on 7 July 2013 that Abu Qatada "agreed" to return to Jordan. ${ }^{504}$

\section{Incorporation of international treaties into China's domestic law}

Before considering this thesis's proposals for what should be contained in an extradition treaty between New Zealand and China below, it is necessary to first consider how China's EL and domestic law would interact with a bilateral extradition treaty and whether the provisions of a treaty would take precedence over the provisions of the EL in the event of a discrepancy. The EL does not explicitly prescribe whether extradition treaties ratified by China should override the EL in the event of an inconsistency. Article 2.2 of the initial draft of the EL provided that "in the case of discrepancy between the extradition treaties and this law, the treaties shall prevail". The Legal Committee of the National People's Congress recommended that this article be amended and moved from

\footnotetext{
${ }^{501}$ Giuffre, above n 242, at 290.

${ }^{502}$ Treaty on Mutual Legal Assistance in Criminal Matters between the United Kingdom of Great Britain and Northern Ireland and the Hashemite Kingdom of Jordan, Jordan United Kingdom of Great Britain and Northern Ireland-Jordan [2013] UKTS 25 (signed 24 March 2013, entered into force 1 July 2013).

${ }^{503}$ Article 27(1)-(4). See Appendix 2 at 131 below.

${ }^{504}$ Giuffre, above n 242, at 290-291.
} 
the Chapter of general Provisions to the Supplementary Articles after the Law's second reading, but this article was deleted at the final reading of the draft law. The amended article would have stated that: ${ }^{505}$

...if the extradition treaties or other treaties in which there is an extradition clause concluded or acceded to by the People's Republic of China contain provisions that differ from those in this law, the provisions of treaties shall apply except for the provision upon which China has made reservations.

This amendment may suggest that the National People's Congress was concerned about the binding effect of such a provision being included in the EL. Nevertheless, article 17 of the CPL stipulates that international judicial assistance in criminal affairs shall be conducted "pursuant to the international treaties concluded or acceded to by China" suggesting that the provisions of an extradition treaty with China would take precedence over the EL in the event that there is a discrepancy. ${ }^{506}$ Despite article 17 of the CPL, it is difficult to assess whether this provision would ensure that the provisions of an extradition treaty with China would take precedence over the EL in the event that there is an inconsistency. The Chinese legal system does not fit snuggly into either the monistic or dualistic views that are typically associated with descriptions of the relationship between international law and domestic law. The Chinese legal system in fact incorporates a fusion of the monist and dualistic processes by which international law is incorporated into Chinese domestic law termed a "dialectical model", which is borrowed largely from soviet legal doctrine. "According to this dialectical view, international law and municipal [or domestic] law are separate systems that are infiltrating and supplementing each other rather than conflicting with each other". 507

One important method by which international treaties are incorporated into domestic law in China is through the adoption of "statutory reference norms" which provide for the application of the provisions of a treaty in the event that national legislation is inconsistent with an international treaty. ${ }^{508}$ Another method of incorporation is by way of the SPC's practice of issuing "judicial interpretations" which mandate application of a treaty norm. ${ }^{509}$ Although article 17 of the CPL appears to provide for a statutory reference norm it would seem prudent to endeavour to avoid outright conflicts between

\footnotetext{
${ }_{505}$ Qian Hu and Qiang Chen "China's Extradition Law of 2000" (2002) 1 Chinese J Int'l L 647 at 652.

${ }^{506}$ At 652. See also Feng Huang "The Establishment and Characteristics of China's Extradition System" (2006) 4 Frontiers Law China 595 at 599.

${ }^{507}$ Bjorn Ahl "Chinese Law and International Treaties" (2009) 39 Hong Kong LJ 735 at 737.

${ }^{508}$ At 746

${ }^{509}$ At 746-747.
} 
the provisions of an extradition treaty and China's domestic criminal and extradition law. Instead the goal should be to formulate an extradition treaty that is complimentary and supplemental to China's domestic law rather than one that attempts to affect a wholesale proscription of perceived inadequacies in the Chinese criminal justice system. There needs to be some acknowledgment of cultural relativism and respect for China's sovereignty when formulating human rights protections within the terms of the treaty. Bearing this in mind the next section considers what human rights protections should be included in an extradition treaty between China and New Zealand.

\section{Proposed human rights protections under the treaty}

(a) Prohibition against imposition of the death penalty

There should be an express prohibition against the imposition of the death penalty on individuals extradited under the treaty. There would still be a determination or decision issued by the SPC not to impose the death penalty in compliance with the EL. This is because article 50 of the EL provides that where the requested state grants extradition with assurances, the Chinese Ministry of Foreign Affairs may make assurances on behalf of the Chinese government. Any assurance relating to the penalty to be imposed is subject to a decision by the SPC. Article 50 further provides that where the extradited individual is found criminally liable, the judiciary will be bound by the assurance made. This is why the SPC issued the following determination, which was presented along with the request for Kim's extradition: ${ }^{510}$

According to Article 50 of Extradition Law of the People's Republic of China, it is hereby decided that,

When Kyungyup Kim is extradited from New Zealand to the People's Republic of China, if he is convicted after trial and the crime for which he is convicted is punishable by death penalty according to Criminal Law, the trial court will not impose the death penalty on him, including death penalty with a two-year reprieve.

This decision was issued in compliance with Article 50. It was not issued as an assurance to the New Zealand government. The assurance should have been given by the Ministry of Foreign Affairs, which is subject to a determination by the SPC. This determination is probably best described as a declaration by the SPC that it will comply with the assurance in accordance with China's domestic law.

${ }^{510}$ Kyung Yup Kim v Minister of Justice, above n 94, at [141]. 


\section{(b) Prohibition against use of torture}

There should be an express provision in the treaty that an individual extradited pursuant to the treaty will not be subject to torture, or other cruel, inhuman or degrading treatment or punishment after surrender to the requesting party. The first assurance given by China in respect of the extradition of Kyung Yup Kim was, as a state party to CAT, to comply with the Convention to ensure Kim will not be subject to torture or other cruel, inhuman and degrading treatment or punishment. It would not be a radical suggestion to simply make compliance with CAT a mandatory condition of any extradition request under the treaty. There is one issue however and that is China's limited definition of torture under its criminal law. The criminalisation of forms of torture under the CL focuses on physical acts of torture and fails to encompass other forms of torture, such as "mental torture". 511 Such criminal offences do not include "other cruel, inhuman or degrading treatment or punishment". 512 There is, therefore, a risk that some forms of torture may not be considered to be such by Chinese law enforcement authorities due to lack of a definition. Furthermore, there is also a risk that some forms of torture will not be recognised by the Chinese courts when considering whether to exclude such evidence at trial. It is therefore suggested that "torture" be defined under the treaty in accordance with the definition in article 1 of CAT for the purposes of dealing with individuals extradited under the treaty. "Cruel, inhuman or degrading treatment or punishment" which falls short of "torture" should also be defined in the treaty in accordance with the conventional definitions under international law.

\section{(c) Provision of a fair trial}

The treaty should provide that an individual extradited under the treaty will receive a trial that does not depart from article 14 of the ICCPR such as to deprive that individual of a key benefit of the right in question. Although this arguably would require a higher standard of compliance with the ICCPR than the "flagrant denial of justice" threshold developed by the ECtHR, it would be in line with current New Zealand case law. ${ }^{513}$ Perhaps a better option would be to provide for the requirement in line with the United Nations Model Treaty on Extradition that the individual extradited under the treaty must receive the "minimum guarantees in criminal proceedings, as contained in the

\footnotetext{
${ }^{511}$ Manfred Nowak 2010 report, above n 120, at 38.

512 See CL arts 247-248.

${ }^{513}$ Kyung Yup Kim v Minister of Justice, above n 94, at [179].
} 
[ICCPR]". ${ }^{514}$ Arguably, this would result in the courts applying much the same test as elucidated by the Court of Appeal in Kyung Yup Kim v Minister of Justice without the connotations often attached to the use of the word "flagrant".

\section{Proposed grounds for refusing surrender}

The usual grounds for refusing extradition, for example the "political offence", "military offence", "discrimination", "double jeopardy", "citizenship" and "humanitarian" grounds should be provided for in the treaty. There should still be grounds for refusing extradition even if the treaty provides for express human rights protections for individuals extradited under the treaty. This is because there may be cases where there is still a risk of an individual being subject to human rights abuses, notwithstanding express human rights protections under the treaty, due to the nature of the offending or the political status of the individual sought for extradition. The grounds for refusing extradition under the treaty should attempt to reflect the grounds for refusal under both China and New Zealand's domestic extradition law. "Citizenship" would have to be a discretionary ground to reflect the ability of New Zealand to extradite its own citizens.

\section{(a) Political offence exception}

Of the extradition treaties signed between China and other Western developed countries considered above, only the treaties with France and Australia did not have exceptions to the political offence ground for refusing extradition. Notably China's EL does not have a political offence exception. The political offence exception was created during the 19th Century by European and Western "liberal nations to support those in the fight against tyranny". 515 If there was to be an exception for terrorist offences included in an extradition treaty between New Zealand and China there would likely be concern that China may use this exception to seek extradition of Chinese dissidents and activists resident in New Zealand by accusing such individuals of committing terrorist offences. A major difficulty with making terrorist offences an exception to the political offence ground for refusing extradition is that there is no internationally accepted definition of the crime of terrorism. ${ }^{516}$ Furthermore, most legal definitions of terrorism are so wide that they encapsulate activity which would not always be considered to constitute

\footnotetext{
${ }_{514}$ ICCPR, art 3(f).

${ }^{515}$ Vincent DeFabo "Terrorist or Revolutionary: The Development of the Political Offender Exception and its Effects on Defining Terrorism in International Law" (2012) 2(2) NSLB 69 at 74.

${ }^{516}$ At 91-92.
} 
conventional acts of terrorism. China's 2015 Counterterrorism Law ${ }^{517}$ is no exception, defining terrorism as "any opinion or action that, by means of violence, sabotage or threat, generates social panic, undermines public security, infringes personal and property rights, and menaces government departments or international organisations, in order to realise its political or ideological purposes". ${ }^{518}$ For this reason it is recommended that there not be an exception to the political offence ground for refusing extradition included in an extradition treaty between New Zealand and China.

(b) Imposition of death penalty

There should be a mandatory ground for refusing extradition in cases where the death penalty will be imposed, unless a determination is provided by the SPC that the relevant court will not impose the death penalty in accordance with the terms of the treaty. This would be desirable because such a determination would provide greater assurance that the Chinese courts will comply with the terms of the treaty. Provision of such a determination by the SPC would be similar to the requirement that the SPC provide a determination under article 50 of the EL with respect to an assurance given by the Ministry of Foreign Affairs. ${ }^{519}$

(c) Subject to torture, or other cruel, inhuman or degrading treatment or punishment

There should be provision for a mandatory ground for refusing extradition where there are substantial grounds for believing the individual sought for extradition, has been, or would be in danger of being subjected to torture or to cruel, inhuman, or degrading treatment or punishment in the requesting country. This proposed formulation of the ground is an amalgamation of the current ground for refusal in the Extradition Act 1999 (NZ) that "there are substantial grounds for believing that the person would be in danger of being subjected to an act of torture" ${ }^{, 520}$ and the ground in China's EL that extradition will be refused where "the person sought has been or will probably be subjected to torture or other cruel, inhuman or humiliating treatment or punishment in the Requesting State". ${ }^{521}$ This would provide better protection than is provided under New Zealand's domestic law at present and be in line with the Law Commission's recommendation to

\footnotetext{
${ }^{517}$ Wanshu Cong “China's 2015 Counterterrorism Law” (2016) 11 J Comp L 381.

${ }^{518}$ At 382 .

519 See Chapter VII C2(a) at 101 above.

${ }^{520}$ Extradition Act 1999, s 30(2)(b).

${ }^{521} \mathrm{EL}$, art 8(7).
} 
include "cruel, inhumane, or degrading treatment or punishment" in its proposed Extradition Act. ${ }^{522}$

(d) Receipt of a trial that does not depart from article 14 of the ICCPR

It is proposed that the best option is to simply use the language of the United Nations Model Treaty on Extradition and provide that extradition must not be granted "[i]f the person whose extradition is requested... has not received or would not receive the minimum guarantees in criminal proceedings, as contained in the [ICCPR]". ${ }^{523}$ This is arguably consistent with the Court of Appeal's "real risk of departure" test, that extradition be refused where there is a real risk that the individual sought for extradition would receive a trial that departs from article 14 of the ICCPR such as to deprive the individual of a key benefit of the right in question. It is not recommended that the treaty use the higher threshold suggested by the Law Commission that extradition should be refused where extradition would be "unjust and oppressive" because of "the likelihood of a flagrant denial of a fair trial in the requesting country". ${ }^{524}$ Not only would the threshold for rejection be higher than the "real risk of departure" test currently applied under New Zealand law, but the use of the word "likelihood" raises the question as to how unlikely a flagrant denial of justice would have to be to justify rejecting an extradition request. There is a risk that the use of the word "likelihood" would be interpreted to mean that the mere possibility or a low probability of a flagrant denial of justice might not be sufficient grounds to justify rejecting a request. This interpretation would be unsatisfactory.

(e) Specific fair trial guarantees

Mirroring the assurances provided by China to New Zealand in relation to Kyung Yup Kim's extradition proceedings, the treaty should expressly provide for the following fair trial guarantees for individuals extradited under the treaty: ${ }^{525}$

1. After surrender an individual will be brought to trial without undue delay.

2. An individual will be entitled to retain a lawyer licenced to practice law in China to defend him or her at trial.

\footnotetext{
${ }^{522}$ Law Commission, above n 2, at 194. Clause 20(a) of the Law Commission's draft Extradition Bill.

${ }^{523}$ United Nations Model Treaty on Extradition, above n 495, art 3(f).

${ }^{524}$ Law Commission, above n 2, at 196.

${ }^{525}$ Assurances 2, 7, and 10. See Appendix 1 at 127 below.
} 
3. An individual will be entitled to meet with his or her lawyer in private without being monitored.

4. The requesting party will provide to the requested party, on request, full and unedited recordings of all pre-trial interrogations of the extradited individual and court proceedings relating to the extradited individual, including recordings of what occurs when the hearing is closed.

Nonetheless, in light of the Court of Appeal's decision in Kyung Yup Kim v Minister of Justice, there would have to be further fair trial guarantees. There should be a mandatory requirement that an individual extradited under the treaty be provided with access to all of the evidence held by the prosecution relevant to the charges faced by that individual. This should be an ongoing requirement throughout the trial process. The treaty should also prohibit prosecution of an extradited individual's defence lawyer under article 306 of the CL for inducing witnesses or an accused to change their evidence. As noted by the Court of Appeal, "[t]here is also an issue as to who [an extradited individual's] legal representative should be" ${ }^{526}$ There may be suitable legal practitioners resident in New Zealand who have the ability to practice law in China that would not fear repercussions for defending an accused in the same way that a local practitioner would. Alternatively, the requirement that the defence lawyer have the ability to practice law in China might be waived in respect of representation of an extradited individual.

The Court of Appeal was satisfied that there should be an assurance that Kim have a legal representative present during interrogations due to the ambiguity of the provisions of article 118 of the CL regarding the right to silence and also due to the risk of torture. ${ }^{527}$ In addition to a requirement that a legal representative be present at interrogations, it is also suggested that there be an express provision in the treaty that an extradited individual has the right not to answer any questions put to him or her in pre-trial interrogations due to the lack of an express right to silence under Chinese law. ${ }^{528}$ Finally, the treaty should place a mandatory requirement for witnesses to attend trial for cross-examination unless consent is provided by the extradited individual to a witness not attending trial.

The Chinese courts should be bound by an express provision in the extradition treaty outlining specific fair trial guarantees. This is because article 17 of the CPL requires international judicial assistance in criminal affairs to be conducted in accordance with the

\footnotetext{
${ }^{526}$ Kyung Yup Kim v Minister of Justice, above n 94, at [256].

${ }^{527}$ At [256].

${ }^{528}$ See Chapter III B(b)(vi) at 29 above.
} 
extradition treaty. However, a suggested means of addressing any possible concerns relating to the Chinese courts' readiness to follow the extradition treaty over the requirements of China's domestic criminal law with respect to the fair trial guarantees, would be to stipulate that the SPC provide a determination that it will comply with the fair trial guarantees under the extradition treaty. This would accord with the SPC's practice of issuing "judicial interpretations" thereby further ensuring incorporation of the conditions of the treaty into China's domestic law. It also accords with the way in which the SPC must make a determination under article 50 of the EL that it will not impose the death penalty. Requiring such a determination from the SPC would effectively force the SPC to acknowledge that it is bound by the fair trial guarantees under the treaty.

\section{(f) Judicial independence}

A much more difficult issue is the risk of interference by the judicial committee in the trial court's decision-making. A study of the archival minutes of a lower level court in Shaanxi province found that the judicial committee for that particular court reviewed 96.8 per cent of all of the criminal cases in 2009 raising questions as to whether the judicial committees' influence is in fact as marginal as some suppose. ${ }^{529}$

It would be desirable to include a further condition in the treaty that the trial court must conduct its decision-making process independently free from interference from the judicial committee. This is so China's judicial committee is not permitted to interfere in the trial court's decision-making in respect of a determination of an extradited individual's criminal trial. The problem with including such a condition is that it would be difficult to monitor compliance with such a condition because interference by the judicial committee in court decision-making is conducted behind closed doors. However, there is evidence to suggest that when a Chinese judge incorporates the decision of the judicial committee into a judgment, the standardised form of such judgments acknowledge that the judgment is in accordance with a decision of the judicial committee of the relevant court. ${ }^{530}$ There would really need to be more transparency about how the judicial committee conducts its affairs in order to decide whether a condition is feasible or how such a condition could be formulated and monitored. Finally, consideration should be given to potentially making it a requirement under the treaty for the SPC, or perhaps preferably the relevant judicial committee itself, to issue a decision that it will

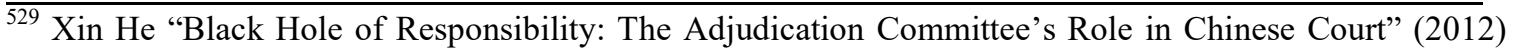
46(4) Law \& Soc'y Rev 681 at 689.

${ }^{530}$ At 688 . 
comply with a condition of the treaty not to interfere in decision-making in order for there to be some guarantee of judicial independence.

\section{Monitoring provisions}

In light of the Court of Appeal's findings in Kyung Yup Kim regarding the risk of torture occurring undetected at times other than during interrogations when the cameras are turned off ${ }^{531}$, it seems unlikely that monitoring measures alone would ever be sufficient protection against the risk of torture when an extradited individual is detained by the Chinese authorities in a detention facility pending trial. It is therefore suggested that extradited individuals not be detained in detention facilities pending trial but instead be subject to "residential surveillance" with electronic monitoring conditions ${ }^{532}$ at a suitable residence more easily monitored by the New Zealand consulate. Checks should be allowed and conducted at random. The use of 24-hour video surveillance monitored by the New Zealand consulate should be considered. The treaty should prohibit pre-trial detention in a detention facility making residential surveillance mandatory for individuals extradited under the treaty.

\section{Taking account of pre-trial detention at sentencing}

As noted by the Court of Appeal in Kyung Yup Kim v Minister of Justice China has concluded extradition treaties with other countries which expressly require the length of time an extradited individual has spent in custody before trial to be deducted from the sentence imposed by the Chinese courts for the offending. ${ }^{533}$ Such a requirement should also be provided for in an extradition treaty. The Court of Appeal refused to consider the argument that life imprisonment without parole would amount to a breach of article 7 of the ICCPR, because of an insufficient evidential basis for the argument, and because Chinese law may provide for commutation of life imprisonment. ${ }^{534}$ If it is not possible to commute a sentence of life imprisonment, to take into account time spent in custody pending trial ${ }^{535}$, then an extradition treaty with China should prohibit the imposition of life imprisonment without parole. ${ }^{536}$

\footnotetext{
${ }^{531}$ Kyung Yup Kim v Minister of Justice, above n 94, at [132].

${ }^{532}$ CPL, arts 72-77.

${ }^{533}$ Kyung Yup Kim v Minister of Justice, above n 94, at [267].

534 At [268].

${ }^{535}$ Commutation of punishment is found in Part One, Chapter IV, Section 6 of the CL, arts 78-80.

536 Perpetrators of violent crimes involving homicide, explosions, robbery, rape and kidnapping are prohibited from being granted parole when sentenced to life imprisonment. See CL, art 81.
} 


\section{Aut dedere aut judicare - obligation to exercise extraterritorial jurisdiction}

All of the extradition treaties signed between Western developed countries and China considered above ${ }^{537}$ included an obligation on the requested party to refer a case to its competent authorities for the purpose of instituting criminal proceedings under its domestic law in the event that a request is refused on the ground that a requested individual is a national of the requested party. In most cases, this would mean that China would be obligated to prosecute an individual by exercising its extraterritorial jurisdiction in cases where a request was refused for the reason that the requested individual was a Chinese national. If a treaty between New Zealand and China included such a provision there should be express provision that the protections and monitoring provisions of the treaty will also apply to a requested individual in the event that China refuses a request on the basis of nationality and exercises its extraterritorial jurisdiction.

As argued above $\mathrm{e}^{538}$ there should be provision in the extradition treaty for New Zealand to offer to exercise its extraterritorial jurisdiction in the event that New Zealand were to refuse a request from China for extradition. Where a request is based on alleged corruption, having the ability to make this offer would coincide with New Zealand's obligations under UNCAC, namely the obligation to consider transferring proceedings where several jurisdictions are involved ${ }^{539}$, and the obligation to take all necessary measures to establish jurisdiction over UNCAC offences when an alleged offender is in New Zealand's territory and New Zealand does not extradite him or her. ${ }^{540}$

\section{Termination and suspension}

Although it is argued here that the purpose of an extradition treaty is not only to facilitate extradition but to also protect individuals extradited under the treaty ${ }^{541}$, it would seem prudent to expressly provide for this purpose or objective in the extradition treaty. This would ensure that any breach of the objective to protect an extradited individual would amount to a material breach of the treaty allowing a party to take countermeasures in the event of a breach of an extradited individual's rights. The treaty could go even further and expressly state that any breach of the specific protections provided for individuals extradited under the treaty will amount to a material breach warranting suspension or

\footnotetext{
${ }^{537}$ See Chapter VII A at 88 above.

${ }^{538}$ See Chapter V C at 74 above.

${ }^{539}$ Article 47.

${ }^{540}$ Article 42(4).

${ }^{541}$ See Chapter VI D3 at 84 above.
} 
termination. Furthermore, the treaty should not only express the effect of termination of the treaty, but there should also be express provision as to the effect of suspension. Suspension should be immediate and apply to all extradition requests under the treaty. There should be consideration as to whether suspension of the treaty may also include mutual assistance requests under the Treaty between New Zealand and the People's Republic of China on Mutual Legal Assistance in Criminal Matters, including a freeze on all proceeds of crime requests under the mutual assistance treaty and MACMA. This added consequence to a material breach would give additional assurance that extradited individuals would receive sufficient protections while detained in China awaiting the determination of criminal proceedings. 


\section{Conclusion: The Need for a Structured Approach to Extradition between China and New Zealand}

As crime increasingly takes on a transnational dimension and China continues to seek extradition of individuals from New Zealand as part of its far-reaching campaign against corruption, New Zealand will increasingly be confronted with human rights issues that arise in respect of its extradition relationship with China. This is due to perceived inadequacies in China's criminal justice system and the practice of using forms of torture to extract confessions by China's law enforcement agencies despite efforts to deter this practice. What is clear is that New Zealand's current ad hoc extradition process with its overreliance on non-binding diplomatic assurances fails to guarantee fair trial rights and protection against torture for individuals extradited to China. What is needed is a more structured approach to New Zealand and China's extradition relationship in the form of a legally binding extradition treaty capable of transcending the disparate aspects of both countries' criminal justice systems by providing specific human rights guarantees. Such a legal framework would in turn provide the certainty that is needed for China to successfully extradite individuals from New Zealand in the future, while at the same time ensuring that New Zealand complies with its international obligations.

The Court of Appeal's decision in Kyung Yup Kim v Minister of Justice ${ }^{542}$ exemplifies the failings of New Zealand's current ad hoc system and its overreliance on diplomatic assurances to circumvent the risk of individuals being subject to human rights abuses after extradition to China. While the Court of Appeal has not closed the door on the possibility of an individual being lawfully extradited to China through the use of diplomatic assurances and monitoring arrangements, the Court's decision leaves great uncertainty as to whether China could ever successfully extradite an individual under the current system. Even with further assurances, it seems difficult to conceive how China could provide an adequate assurance that the Chinese judicial committee will not interfere in the trial court's decision-making as there is insufficient transparency regarding how the judicial committee conducts its affairs behind closed doors and the difficulty in monitoring the trial court's interactions with the judicial committee. Even if China is one day able to extradite an individual in reliance on diplomatic assurances, questions remain as to whether New Zealand's current extradition system would be capable of extraditing a high profile individual accused of corruption in China.

\footnotetext{
${ }^{542}$ Kyung Yup Kim v Minister of Justice, above n 94.
} 
The internal workings of factional politics within the CCP is at best a murky world, which creates speculation as to what the Chinese government's true motivations are for prosecuting government officials for corruption. It is clear that Xi Jinping's anticorruption campaign is being used unevenly as a political tool to suppress rival factions and consolidate power within the CCP. It seems fair to assume that reliance on diplomatic assurances alone would be insufficient to address New Zealand's international obligations with respect to ensuring protection against torture and fair trial rights for a high profile individual accused of corruption. On the other hand, as a state party to UNCAC, New Zealand would be obliged under UNCAC to extradite an individual accused of corruption. There is a greater likelihood of political interference in cases involving corruption and a greater risk of torture in cases involving investigation by the CCDI. This is because the CCDI is a security agency with extra-legal powers unregulated by China's CPL. It seems likely that diplomatic assurances alone would be insufficient to quell concerns regarding adequate protections for a high profile individual accused of corruption in China, when the security agency tasked with overseeing the investigation of such individuals is not even subject to Chinese law.

It may well be that the only way in which New Zealand can fulfil its obligations under UNCAC in cases involving corruption alleged to have occurred in China would be for New Zealand to exercise its extraterritorial jurisdiction. For example, William Yan voluntarily returned to face trial in China after agreement with the Chinese government that he would be returned to New Zealand irrespective of the sentence that would be imposed. This was after the New Zealand authorities agreed to prosecute Yan for money laundering in New Zealand. William Yan's case could provide a model for an alternative means by which to deal with alleged economic fugitives from China currently residing in New Zealand. Instead of individuals accused of corruption in China being extradited to China for prosecution, such individuals could instead be prosecuted in New Zealand for the offending that allegedly occurred in China under New Zealand's extraterritorial jurisdiction. Accordingly, an extradition treaty with China should allow either state party to offer to try an individual sought for extradition by the other party under that party's extraterritorial jurisdiction as an alternative to extradition. Of course New Zealand would only be able to make such an offer in circumstances where the New Zealand courts have jurisdiction over the offending concerned. In cases involving economic fugitives the applicable offending would usually involve laundering of proceeds of crime in China. Consideration should also be given to expanding the scope of New Zealand's extraterritorial criminal jurisdiction in respect of individuals requested for extradition under an extradition treaty with China. Furthermore, an extradition treaty with China 
should also include a comprehensive asset sharing regime to determine how proceeds of crime should be shared between the parties at the conclusion of an extraterritorial prosecution.

Utilisation of New Zealand's extraterritorial jurisdiction would be a viable means by which to prosecute individuals accused of corruption in line with New Zealand's obligations under UNCAC, while at the same time avoiding the human rights issues that arise in respect of extradition of such individuals to China. Notwithstanding this conclusion, the parties to the treaty and their respective prosecuting authorities would have to be cognisant of the human rights issues that arise in respect of extraterritorial prosecutions. Defendants to such cases must be able to utilise mutual legal assistance between the parties to obtain exculpatory evidence. Prosecutors and government officials must not be swayed by international or domestic political pressure when deciding whether to prosecute such individuals extraterritorially. Furthermore, due to extraterritorial prosecutions necessarily requiring mutual legal assistance, government officials and prosecutors would need to be cognisant of the risks involved, not only with respect to an accused's rights, but also the risks to other individuals that may be called upon to provide statements and give evidence at trial. This would be particularly important in cases where those other individuals are alleged co-conspirators who could face prosecution in respect of the alleged offending as a result of a request for mutual legal assistance.

The Law Commission published a report in February 2016 outlining its proposals for replacement of the current Extradition Act 1999 and MACMA along with draft Bills to replace both Acts. The Law Commission proposes that the legislation will be a 'baseline' which bilateral extradition treaties will merely supplement and considers that protection for individuals subject to extradition requests is best served through providing for protections in domestic statute than relying on extradition treaties. This approach fails to comprehend the essential role bilateral extradition treaties are likely to play in terms of New Zealand's extradition relationships with countries such as China in the future. Domestic extradition law coupled with an ever increasing reliance on diplomatic assurances to circumvent breaches of international human rights law will never be an adequate substitute for the binding structures that constitute bilateral extradition treaties. Treaty law will never merely supplement domestic legislation. In reality New Zealand's domestic extradition law is merely a substructure on which bilateral extradition treaties will be constructed, which one day will facilitate and supplement more structured extradition relationships governed by bilateral extradition treaties. The Law 
Commission's recommendations for reform should by no means be viewed as constituting the quintessential model for governing New Zealand's extradition relationships with countries such as China going forward.

A legally binding treaty with China that provides for specific fair trial guarantees and a monitoring regime is the only way forward with respect to addressing the human rights issues surrounding extradition of individuals to China in reliance on non-binding diplomatic assurances. However, merely concluding a treaty with China following the United Nations Model Treaty on Extradition or by following a standard extradition treaty format similar to the treaties China has already signed with other Western developed nations would do little to remedy these issues. An extradition treaty following the traditional model would do little more than place an additional obligation on New Zealand to extradite to China allowing the insufficiencies associated with non-binding diplomatic assurances to remain. Concluding an extradition treaty with China following the orthodox model would be unsatisfactory as the only way to truly address the inadequacies of New Zealand's ad hoc extradition system is by concluding an extradition treaty with China that incorporates human rights guarantees and monitoring arrangements into the treaty itself. This is exactly what transpired between the United Kingdom and Jordan as a result of the ECtHR's decision in Othman (Abu Qatada) $v$ United Kingdom. ${ }^{543}$ Not surprisingly the appellant in that case only "agreed" to return to Jordan following the ratification of a 'mutual legal assistance agreement' between the United Kingdom and Jordan, which explicitly guarantees a number of fair trial rights for deportees and prohibits the use of evidence obtained via torture at trial.

Due to China's strong ideological position with regards to protecting its state sovereignty and self-determination, it seems unlikely that China would agree to the incorporation of a compulsory dispute settlement mechanism into an extradition treaty with New Zealand or consent to referral of a dispute to the ICJ in the event of a dispute over the interpretation of the extradition treaty. However, New Zealand could terminate or suspend the operation of the treaty in the event of a "material breach" consisting of a violation of a provision essential to the accomplishment of the object or purpose of the treaty. An extradition treaty incorporating fair trial guarantees and monitoring arrangements would allow New Zealand to suspend the extradition of all individuals sought for extradition by China until a material breach of the treaty's provisions are remedied or the individual concerned is returned to New Zealand. Crucially, suspension would be a far more immediate consequence of non-compliance than the political consequences of breaching a

\footnotetext{
${ }_{543}$ Othman (Abu Qatada) v United Kingdom, above n 207.
} 
diplomatic assurance could ever provide. A treaty would provide New Zealand with an immediate response to a breach of its terms in contrast to the piecemeal and somewhat delayed response available under New Zealand's current ad hoc system.

Nonetheless, there are some challenges that may not be capable of being adequately remedied even by a binding treaty formulated in the way envisaged by this thesis. For instance, it is unclear whether a treaty could address China's lack of judicial independence due to a lack of transparency and uncertainty regarding how the Chinese courts' judicial committee conducts its affairs behind closed doors. This lack of transparency would make monitoring of the judicial committee's conduct almost impossible. The writer has endeavoured to address such challenges by suggesting that the SPC or the relevant judicial committee issue a determination that the judicial committee will abide by a condition in the treaty prohibiting interference in the decision-making of the trial court. This is reminiscent of the SPC's practice of issuing "judicial interpretations" which can mandate application of treaty norms thereby incorporating treaty law into China's domestic law. The viability of a treaty condition being utilised to address the judicial committee's interference in decision-making really hinges on provision of further information regarding the extent of the judicial committee's ability to influence decision-making in criminal trials and potential reform of China's domestic law with respect to the judicial committee's role in the Chinese judicial system. 


\section{Bibliography}

\section{A Cases}

1 New Zealand

Attorney-General (Minister of Immigration) v Tamil X [2010] NZSC 107, [2011] 1 NZLR 721.

Commissioner of Police v William Yan [2016] NZHC 919.

Commissioner of Police v William Yan [2016] NZHC 1822.

Dotcom v United States of America [2014] NZSC 24, [2014] 1 NZLR 355.

Hutton v R [2018] NZHC 662.

Kim v The Prison Manager Mt Eden Correctional Facility [2012] NZCA 471, [2012] 3 NZLR 845.

Kim v Minister of Justice [discharge application] [2016] NZHC 1491.

Kyung Yup Kim v Minister of Justice [2016] NZHC 1490, [2016] 3 NZLR 425 [first judicial review].

Kyung Yup Kim v Attorney General [bail decision] [2016] NZHC 2235.

Kyung Yup Kim v Minister of Justice [2017] NZHC 2109, [2017] 3 NZLR 823 [second judicial review].

Kyung Yup Kim v Minister of Justice [2019] NZCA 209.

Poynter v Commerce Commission [2010] NZSC 38, [2010] 3 NZLR 300.

$R v$ Darwish [2006] 1 NZLR 688 (HC).

$R v$ Johnston (1984) 2 CRNZ 289 (CA).

$R v$ Standard 304 Ltd [2008] NZCA 564, [2010] NZAR 194.

Saxton v Police [1981] 2 NZLR 186 (CA).

Smith v Police [2018] NZHC 878.

Taunoa v Attorney-General [2007] NZSC 70, [2008] 1 NZLR 429, (2007) 9 HRNZ 104.

Tipple v Pain [1983] NZLR 257 (HC).

2 Australia

Motiv The Queen (2011) 238 ALR 393 (HCA). 
$R v$ Martens [2009] QCA 351; 235 CLR 371; [2011] 1 Qd R 575; 262 ALR 106; 216 A Crim R 1; 235 FLR 371 (QSC).

$R v$ Moti [2009] QSC 407 (QSC).

3 Canada

Lai v Canada (Minister of Citizenship and Immigration) 2007 FC 361, [2008] 2 FCR 3 (FC).

4 European Union

Othman (Abu Qatada) v United Kingdom (8139/09) Section IV, ECHR 17 January 2012.

Soering $v$ United Kingdom (1989) 11 EHRR 439 (ECHR).

5 International Court of Justice

Gabcikovo-Nagymaros Project (Hungary v Slovakia) [1997] ICJ Rep 7.

Nuclear Tests (Australia v France) [1974] ICJ Rep 253.

Nuclear Tests (New Zealand v France) [1974] ICJ Rep 457.

6 United Kingdom

Belhaj v Straw [2017] UKSC 3; [2017] HRLR 4; [2017] AC 964; [2017] 3 All ER 337; [2017] 2 WLR 456.

$B H(A P)$ v The Lord Advocate [2012] UKSC 24.

BHv KAS or Hv The Lord Advocate [2011] HCJAC 77.

Office of the King's Prosecutor, Brussels v Cando Armas [2006] 2 AC 1, [2005] UKHL 67.

7 United States of America

Wang v Reno 81 F 3d 808 (9th Cir 1996) (The Goldfish Case).

Xiao v Reno 837 F Supp 1506 (ND Cal 1993) (The Goldfish Case).

\section{B Legislation}

$1 \quad$ New Zealand

Bail Act 2000.

Crimes Act 1961.

Criminal Procedure (Mentally Impaired Persons) Act 2003

Criminal Procedure Act 2011. 
Extradition Act 1870 (Imp)

Extradition Act 1999.

Films, Videos, and Publications Classification Act 1993.

Fugitive Offenders Act 1881 (Imp).

Mutual Assistance in Criminal Matters Act 1992.

New Zealand Bill of Rights Act 1990.

\section{Australia}

Extradition Act 1988 (Cth)

3 Hong Kong Special Administrative Region

Criminal Jurisdiction Ordinance (Cap 461).

4 People's Republic of China

Extradition Law of the People's Republic of China.

Criminal Procedure Law of the People's Republic of China 2012.

Criminal Law of the People's Republic of China.

$5 \quad$ Russia

Constitution of the Russian Federation.

\section{United Kingdom}

Extradition Act 2003

\section{Treaties and Model Treaties}

European Convention on Human Rights 213 UNTS 221 (opened for signature 4 November 1950, entered into force 3 September 1953).

Extradition Treaty between the French Republic and the People's Republic of China, France-China (signed 20 March 2007, entered into force 17 July 2015).

Extradition Treaty between the People's Republic of China and the Italian Republic, Italy-China (signed 7 October 2010, entered into force 13 December 2015).

Extradition Treaty between the People's Republic of China and the Kingdom of Spain, Spain-China (signed 14 November 2005, entered into force April 2007).

International Convention for the Suppression of Terrorist Bombings 2149 UNTS 256 (opened for signature 12 January 1998, entered into force 23 May 2001). 
International Convention for the Suppression of the Financing of Terrorism 2178 UNTS 197 (opened for signature 10 January 2000, entered into force 10 April 2002).

International Covenant on Civil and Political Rights 999 UNTS 171 (opened for signature 16 December 1966, entered into force 23 March 1976).

Model Treaty on Extradition GA Res 45/116, A/Res/45/116 (1990).

Model Treaty on Mutual Assistance in Criminal Matters GA Res 45/117, A/Res/45/117 (1990).

United Nations Convention on the Rights of the Child 1577 UNTS 3 (opened for signature 20 November 1989, entered into force 2 September 1990).

Optional Protocol to the Convention against Torture and other Cruel, Inhuman or Degrading Treatment or Punishment 2375 UNTS 237 (opened for signature 18 December 2002, entered into force 22 June 2006).

Optional Protocol to the Convention on Rights of the Child on the Sale of Children, Child Prostitution and Child Pornography 2171 UNTS 227 (opened for signature 25 May 2000, entered into force 18 January 2002).

Optional Protocol to the International Covenant on Civil and Political Rights 999 UNTS 302 (opened for signature 16 December 1966, entered into force 23 March 1976).

Protocol against the Smuggling of Migrants by Land, Sea and Air 2241 UNTS 507 (opened for signature 15 November 2000, enter into force 28 January 2004).

Protocol to Prevent, Suppress and Punish Trafficking, Especially Women and Children 2237 UNTS 319 (opened for signature 15 November 2000, enter into force 25 December 2003).

Second Optional Protocol to the International Covenant on Civil and Political Rights 999 UNTS 414 (opened for signature 15 December 1989, entered into force 11 July 1991).

Treaty between New Zealand and the People's Republic of China on Mutual Legal Assistance in Criminal Matters, New Zealand-China [2008] NZTS 1 (signed 6 April 2006, entered into force 1 January 2006).

Treaty between the Portuguese Republic and the People's Republic of China on Extradition, Portugal-China (signed January 2007, entered into force July 2009).

Treaty on Extradition between Australia and the People's Republic of China, AustraliaChina (signed 6 September 2007, not yet in force). 
Treaty on Mutual Legal Assistance in Criminal Matters between the United Kingdom of Great Britain and Northern Ireland and the Hashemite Kingdom of Jordan, Jordan United Kingdom of Great Britain and Northern Ireland-Jordan [2013] UKTS 25 (signed 24 March 2013, entered into force 1 July 2013).

United Nations Convention against Torture and Other Cruel, Inhuman or Degrading Treatment or Punishment, 1465 UNTS 85, (opened for signature 10 December 1984, entered into force 26 June 1987).

United Nations Convention against Transnational Organised Crime 2225 UNTS 209 (opened for signature 15 November 2000, entered into force 29 September 2003).

United Nations Convention on the Rights of the Child 1577 UNTS 3 (opened for signature 20 November 1989, entered into force 2 September 1990).

United Nations Convention against Corruption 2349 UNTS 41 (opened for signature 9 December 2003, entered into force 14 December 2005).

Vienna Convention on the Law of Treaties 1155 UNTS 331 (opened for signature 29

April 1970, entered into force 27 January 1980).

\section{Books and Chapters in Books}

Anthony Aust Modern Treaty Law and Practice (2nd ed, Cambridge University Press, New York, 2007).

John Garnaut The Rise and Fall of the House of Bo: How a Murder Exposed the Cracks in China's Leadership (eBook ed, Penguin, 2012).

$\mathrm{Fu}$ Hualing "Weilding the sword: President Xi's new anti-corruption campaign" in S Rose-Ackerman and Paul Lagunes (eds) Greed, Corruption, and the Modern State (Edward Elgar Publishing Limited, Cheltenham, United Kingdom, 25 September 2015) 135.

Jan Klabbers The Concept of Treaty in International Law (Kluwer Law International, The Hague, 1996).

Willy Wo-Lap Lam Chinese Politics in the Era of Xi Jinping: Renaissance, Reform, or Retrogression? (Routledge, New York, 2015).

Vladyslav Lanovoy Complicity and Its Limits in the Law of International Responsibility (Bloomsbury Publishing PLC, London, 2016).

Claire Mitchell Aut Dedere Aut Judicare: the Extradite or Prosecute Clause in International Law (Graduate Institute Publications, Geneva, 2009). 
Alexander V Pantsov and Steven I Levine Deng Xiaoping: A Revolutionary Life (Oxford University Press, Oxford, 2015).

Randall Peerenboom (ed) Judicial Independence in China: Lessons for Global Rule of Law Promotion (Cambridge University Press, New York, 2010).

Frederick C Teiwes Politics at Mao's Court: Gao Gang and Party Factionalism in the Early 1950s (Routledge, London and New York, 2015).

Peng Wang, The Chinese Mafia: Organized Crime, Corruption, and Extra-Legal Protection (Oxford University Press, Oxford, 2017).

\section{E Journal Articles}

Bjorn Ahl "Chinese Law and International Treaties” (2009) 39 Hong Kong LJ 735.

Clive Ansley "The Chinese Judicial System: A Fairy Tale of Beijing" the Verdict (British Columbia, March 2007).

David Aronofsky and Jie Qin "US International Narcotics Cases: Legal Trends and Developments with Implications for US-China Drug Enforcement Activities” (2011) 19 Mich St U Coll L J Int'1 L 279.

Volker Behr "Development of a New Legal System in the people's Republic of China" (2007) 67 Lou L Rev 1161.

Ira Belkin "China's Criminal Justice System: A Work in Progress" (2000) 6(2) Washington Journal of Modern China 61.

Ira Belkin "China's Tortuous Path Towards Ending Torture in Criminal Investigations" (2010-2011) 24 Colum J Asian L 273.

Matthew Bloom “A Comparative Analysis of the United States's Response to Extradition Requests from China" (2008) 33 Yale J Int'l L 177.

Roderic Broadhurst and Peng Wang "After the Bo Xilai Trial: Does Corruption Threaten China's future?" (2014) 56(3) Survival 157.

David Caruso and Zhuhao Wang "Is an oral-evidence based criminal trial possible in China?" (2017) 21 The International Journal of Evidence and Proof 52.

Wanshu Cong “China’s 2015 Counterterrorism Law” (2016) 11 J Comp L 381.

Melissa Curley and Elizabeth Stanley "Extraterritorial Jurisdiction, Criminal Law and Transnational Crime: Insights from the Application of Australia's Child Sex Tourism Offences" (2016) 28 Bond L Rev 169. 
Vincent DeFabo "Terrorist or Revolutionary: The Development of the Political Offender Exception and its Effects on Defining Terrorism in International Law" (2012) 2(2) NSLB 69.

John Dugard and Christine van den Wyngaert "Reconciling Extradition with Human Rights” (1998) 92 Am J Intl L 187 at 212.

$\mathrm{H} \mathrm{L} \mathrm{Fu} \mathrm{"The} \mathrm{Relevance} \mathrm{of} \mathrm{Chinese} \mathrm{Criminal} \mathrm{Law} \mathrm{to} \mathrm{Hong} \mathrm{Kong} \mathrm{and} \mathrm{Its} \mathrm{Residents"}$ (1997) 27 Hong Kong L J 229.

Geoff Gilbert "Who has Jurisdiction for Cross-Frontier Financial Crimes?" (1995) 2 Web JCLI 1.

Mariagiulia Giuffre "An Appraisal of Diplomatic Assurances One Year after Othman (Abu Qatada) v United Kingdom (2012) (2013) 2 Int'l Hum Rts L Rev 266.

Amanda Haasz "Underneath It All: Policing International Child Pornography on the Dark Web” (2016) 43 Sy J Int L 353.

Xin He "Black Hole of Responsibility: The Adjudication Committee's Role in Chinese Court” (2012) 46(4) Law \& Soc'y Rev 681.

Qian Hu and Qiang Chen "China's Extradition Law of 2000” (2002) 1 Chinese J Int'l L 647.

Feng Huang "The Establishment and Characteristics of China's Extradition System" (2006) 1 Frontiers L China 595.

Danielle Ireland-Piper "Extraterritorial Criminal Jurisdiction: Does the Long Arm of the Law Undermine the Rule of Law?” (2012) 13 Melb J Int'1 L 122.

Margaret Lewis "Presuming Innocence, or Corruption, in China" (2012) 50 Colum J Transnat'1 L 287.

Anna MacCormack "The United States, China, and Extradition: Ready for the Next Step?” (2008-2009) 12 NYU J Legis \& Pub Pol’y 445.

Yu Mou "The Constructed Truth: The Making of Police Dossiers in China" (2017) 26 Social and Legal Studies 69.

Gregor Noll "Diplomatic Assurances and the Silence of Human Rights Law" (2006) 7 Melb J Int'1 L 104.

Hu Qian and Chen Qiang “China's Extradition Law of 2000” (2002) 1 Chinese J Int'l L 647.

John Quigley “Socialist Law and the Civil Law Tradition” (1989) 37 Am J Comp L 781. 
Francis Regan "Going to Court in China: Observations on a Minor Criminal Case” (2009) 34 Alternative L J 111.

Eleanor Ross "Increasing United States-China Cooperation on Anti-Corruption: Reforming Mutual Legal Assistance” (2018) 86 Geo Wash L Rev 839.

Chen Ruihua “China's New Exclusionary Rule: An Introduction” (2010-2011) 24 Colum J Asian L 229.

Flora Sapio “The Devil’s Proof” (2012) 21 Hum Rts Defender 10.

Lena Skoglund "Diplomatic Assurances Against Torture - An Effective Strategy?" (2008) 77 Nordic J Int'1 L 319.

Nigel Stobbs “The Law and Policy Context of Extradition from Australia to the People's Republic of China" (2017) 7 Victoria U L \& Just J 32.

Aristi Volou “Are Diplomatic Assurances Adequate Guarantees of Safety Against Torture and Ill-Treatment? The Pragmatic Approach of the Strasbourg Court" (2015) 4 UCLJLJ 32.

\section{F Parliamentary and Government Materials}

“China Extradition Treaty” (28 March 2017) Australian Government Department of Foreign Affairs and Trade $<$ www.dfat.gov.au $>$.

Ministry of Health Amphetamine Use 2015/16: New Zealand Health Survey (December 2016).

\section{$G$ Reports}

Committee Against Torture Concluding observations on the fifth periodic report of China $\mathrm{CAT} / \mathrm{C} / \mathrm{CHN} / \mathrm{CO} / 5$ (2016).

Joint Human Rights Committee Allegations of UK Complicity in Torture (21 July 2009) $<$ www.parliament.uk $>$.

Joint Standing Committee on Treaties "Report 167 Nuclear Cooperation-Ukraine; Extradition-China" (December 2016) Parliament of Australia <www.aph.gov.au>.

Law Commission Extradition and Mutual Assistance in Criminal Matters (NZLC IP37, 2014).

Law Commission Modernising New Zealand's Extradition and Mutual Assistance Laws (NZLC R137, 2016). 
Manfred Nowak Civil and Political Rights, Including the Question of Torture and Detention: Report of the Special Rapporteur on torture and other cruel, inhuman or degrading treatment or punishment: Mission to China E/CN4/2006/6/Add6 (2006).

Manfred Nowak Report of the Special Rapporteur on torture and other cruel, inhuman or degrading treatment or punishment: Follow-up to the recommendations made by the Special Rapporteur A/HRC/13/39/Add6 (2010).

\section{H Theses and Dissertations}

Joanna Judge "Modernising New Zealand's Extradition Law: A Critique of the Law Commission's Proposal" (LLB (Hons) Dissertation, Victoria University of Wellington, 2016).

Jack Wong "Trickled-down Assurances: Could the Central Authority, Treaty, or Judiciary Alleviate Extradition Issues Amongst Non-traditional Treaty Partners?" (LLM Thesis, Victoria University of Wellington, 2018).

\section{Internet Sources}

中国人大网“中华人民共和国和意大利共和国引渡条约”全国人民代表大会

$<$ www.npc.gov.cn>. (translation: China National People's University "Extradition Treaty between the People's Republic of China and the Italian Republic" The National People's Congress of the People's Republic of China $<$ www.npc.gov.cn $>$ ).

中国人大网“中华人民共和国和西班牙王国引渡条约”全国人民代表大会

<www.npc.gov.cn>. (translation: China National People's University "Extradition Treaty between the People's Republic of China and the Kingdom of Spain" The National People's Congress of the People's Republic of China <www.npc.gov.cn>).

"Decision of the Standing Committee of the National People's Congress on Ratifying the Extradition Treaty between the People's Republic of China and the Republic of Portugal" (28 October 2008) Law Info China <www.lawinfochina.com>.

Thomas Eder, Bertram Lang, Moritz Rudolf "China's Global Law Enforcement Drive: The need for a European response" (18 January 2017) Merics: Mercator Institute for China Studies $<$ www.merics.org $>$.

Global Legal Research Center "Law on Extradition of Citizens" (July 2013) The Law Library of Congress $<$ www.loc.gov $>$.

Human Rights Watch "Tiger Chairs and Cell Bosses: Police Torture of Criminal Suspects in China" (13 May 2015) Human Rights Watch <www.hrw.org>. 
中央纪委国际合作局 "中国对外缔结的引渡条约清单” (2017年12月 8 日) 全国人民代表大会 $<$ www.npc.gov.cn>. (translation: International Cooperation Bureau of the Central Commission for Discipline Inspection "List of extradition treaties concluded by China" (8 December 2017) The National People's Congress of the People's Republic of China $<$ www.npc.gov.cn>).

Law Press China "China's judicial assistance" (21 July 2015) The Supreme People's Court of the People's Republic of China <www.english.court.gov.cn>.

Interview with Cheng Li (Phd, Princeton University), Director of Research and a Senior Fellow at the Brookings Institution's John L Thornton China Center (Anton Wishik, The National Bureau of Asian Research, 18 April 2012) <www.nbr.org $>$.

Interview with Scott Stewart, Vice President of Tactical Analysis at Stratfor (Marco Wermand, Public Radio International, 19 July 2019) <www.pri.org $>$.

Sam Sachdeva, "Peters pulls his punches on China" (13 November 2017) $<$ www.newsroom.co.nz>.

Sam Sachdeva "Chinese fugitive makes "voluntary' return from NZ" (17 December 2018) Newsroom <www.newsroom.co.nz>.

Statistics New Zealand "Trade with China nearly tripled in past decade" (7 September 2016) StatsNZ < www.m.stats.govt.nz $>$.

Xinhua "China ratifies extradition treaty with Italy" (22 July 2015) The Supreme People's Court of the People's Republic of China <www.english.court.gov.cn>.

Xinhau "China ratifies extradition treaty with Spain" (29 April 2006) The State Council of the People's Republic of China <www.english.gov.cn>.

\section{$J \quad$ Newspaper and Magazine Articles}

Christopher Bodeen "Rising political star in China under investigation for corruption" The Globe and Mail <www.theglobeandmail.com>.

Stephen Dziedzic, "Australia-China extradition treaty pulled by Federal Government after backbench rebellion" ABC News (online ed, Australia, 28 March 2017).

John Garnaut "The Revenge of Wen Jiabao" Foreign Policy (online ed, Washington, 29 March 2012).

Celia Hatton "China corruption: Life term for ex-security chief Zhou" $B B C$ (online ed, London, 11 June 2015). 
Chen Heying "Sino-French extradition treaty begins operating" Global Times (online ed, China, 18 July 2018).

Qin Jize "Treaty on extradition signed" China Daily (online ed, China, 7 September 2007).

Sidney Leng "China ends presidential term limits, but what other changes were made to the constitution?" South China Morning Post (online ed, Hong Kong, 11 March 2018).

Demelza Leslie "China seeks extradition treaty with NZ" Radio New Zealand (online ed, New Zealand, 19 April 2016).

Andrei Lungu "Xi Jinping Has Quietly Chosen his Own Successor" Foreign Policy (online ed, Washington, 20 October 2017).

Katsuji Nakazawa "Xi silences once-powerful youth league and former president's protégé” Nikkei Asian Review (online ed, Tokyo, 25 September 2017).

Nathaniel Popper "Dark Wed Drug Sellers Dodge Police Crackdowns" The New York Times (online ed, New York, 11 June 2019).

"Portugal blocks 2 China extraditions" United Press International (online ed, Washington, 7 July 1995).

"Report: China to investigate former security czar" The New Zealand Herald (online ed, Auckland, 30 August 2013).

Jared Savage "China deports drug suspect" New Zealand Herald (Auckland, 16 July 2015).

Jared Savage "Controversial Citizen William Yan AKA Bill Liu admits money laundering of "significant sums"' The New Zealand Herald (online ed, Auckland, 10 May 2017).

"Taxi driver murder case continues" The New Zealand Herald (online ed, Auckland, 2 August 2011).

"Xi curbs disloyalty as Communist party expels former rising star" The Guardian (online ed, London, 30 September 2017).

\section{$K$ Other Resources}

Anti-Terrorism Resolution of the United Nations Security Council S/Res/1373 (2001).

"Four of China's 'most wanted' for alleged corruption are reported to be hiding out in Auckland' New Zealand Herald (online ed, Auckland, 28 April 2017). 


\section{Appendix 1: China's assurances}

China gave the following assurances to the New Zealand government with respect to Kyung Yup Kim's extradition to China:

(a) First assurance

As a State Party to CAT, the People's Republic of China (PRC) will comply with the Convention to ensure Mr. Kim Kyung Yup will not be subject to torture or other cruel, inhuman and degrading treatment or punishment. The PRC side will honour the above assurances.

(b) Second assurance

After surrender to the PRC from New Zealand, Mr. Kim Kyung Yup will be brought to trial without undue delay, pursuant to the Criminal Procedure Law of the People's Republic of China.

(c) Third assurance

During all periods of Mr. Kim Kyung Yup's detention following his surrender, including pre-trial detention, New Zealand diplomatic or consular representatives will be informed in a timely manner of where Mr. Kim Kyung Yup is detained and of any changes to the place of his detention.

(d) Fourth assurance

During all periods of Mr. Kim Kyung Yup's detention following his surrender, including pre-trial detention, Mr. Kim Kyung Yup will be able to contact New Zealand diplomatic or consular representatives at all reasonable times, and PRC authorities will provide the facilities for him to do so. Such contact may be by facsimile, email or telephone, and will not be censored or edited in any way. Any such contact with New Zealand diplomatic or consular representatives under this paragraph will be used for the sole purpose of obtaining information on the treatment of Mr. Kim Kyung Yup and will not otherwise be disclosed to third parties. 
(e) Fifth assurance

During all periods of Mr. Kim Kyung Yup's detention following his surrender, including pre-trial detention, New Zealand diplomatic or consular representatives may visit $\mathrm{Mr}$.

Kim Kyung Yup at his place of detention and may be accompanied by one or more of the following people chosen by New Zealand diplomatic or consular representatives:

(i) an interpreter;

(ii) a medical professional(s) (including physician, dentist, and psychiatric expert) qualified to practise in the PRC;

(iii) a legal expert licensed to practise law in the PRC.

Such visits will be on a regular basis and permitted once every fifteen days. The PRC authorities will arrange additional visits on request by New Zealand diplomatic or consular representatives. Such visits will include the opportunity:

(i) to interview Mr. Kim Kyung Yup. The interview will, on request by the New Zealand diplomatic or consular representatives, be in private and without being monitored. The PRC will provide safe facilities for such interviews to take place;

(ii) for Mr. Kim Kyung Yup, if he consents, to be examined by the medical professional(s) chosen by New Zealand diplomatic or consular representatives; such examination will be in private, although a medical professional chosen by the PRC authorities may be present at a physical examination;

(iii) to access the parts of the detention facility to which Mr. Kim Kyung Yup has access, including his living quarters.

New Zealand diplomatic or consular representatives will have the opportunity to meet with other persons in private including prison staff, procuratorate, medical professionals, and, with Mr. Kim Kyung Yup's consent, his lawyer.

New Zealand diplomatic or consular representatives will have the opportunity to access other information relevant to the treatment of Mr. Kim Kyung Yup as well as his conditions of detention.

New Zealand diplomatic or consular representatives will conduct such activities for the sole purpose of obtaining information on the treatment of Mr. Kim Kyung Yup and will not otherwise disclose the information to third parties. 
(f) Sixth assurance

There will be no reprisal against persons who supply information regarding Mr. Kim Kyung Yup's treatment to New Zealand diplomatic or consular representatives, if the information is provided in good faith.

(g) Seventh assurance

Mr. Kim Kyung Yup will be entitled to retain a lawyer licensed to practice law in the PRC to defend him. He shall also have the right to dismiss that lawyer and retain another of his choosing. Mr. Kim Kyung Yup shall be entitled to meet with his lawyer in private without being monitored. In addition, he has the right to receive legal aid according to Chinese law.

(h) Eighth assurance

New Zealand diplomatic or consular representatives will be informed of, and will be able to attend, any open court hearing relating to Mr. Kim Kyung Yup. If, pursuant to the CPL and the Criminal law of the PRC, the hearing is closed, those periods shall be as short as possible.

(i) Ninth assurance

New Zealand diplomatic or consular representatives will be provided with information about the status of the case by the PRC authorities.

(j) Tenth assurance

The PRC will, on request, provide New Zealand diplomatic or consular representatives with full and unedited recordings of all:

(i) pre-trial interrogations of Mr. Kim Kyung Yup;

(ii) court proceedings relating to Mr. Kim Kyung Yup, including recordings during any period when the hearing is closed.

Any recordings provided under this paragraph to New Zealand diplomatic or consular representatives will be used for the sole purpose of obtaining information on the treatment of Mr. Kim Kyung Yup and in respect of paragraph 11, and will not otherwise be disclosed to third parties. 
(k) Eleventh assurance

The PRC will, in its dealings with Mr. Kim Kyung Yup, comply with applicable international legal obligations and domestic requirements regarding fair trial.

(1) Twelfth assurance

In the event of any issue arising in relation to the interpretation or application of these assurances, including any issue arising in relation to the treatment of Mr. Kim Kyung Yup, the PRC and New Zealand will immediately enter into consultations in order to resolve the issue in a manner satisfactory to both sides. The Department of Treaty and Law of the Ministry of Foreign Affairs of the PRC, and the New Zealand Embassy in the PRC will facilitate contact between New Zealand and the PRC for all issues related to the above assurances. 


\section{Appendix 2: Article 27 of the Treaty on Mutual Assistance in Criminal Matters between the United Kingdom of Great Britain and Northern Ireland and the Hashemite Kingdom of Jordan}

1. Where a person is returned under this Chapter the Contracting States shall ensure the provisions in this Article shall apply in respect of any criminal trial in the receiving State against such a person in relation to charges notified under Article 26(3).

2. In respect of a criminal trial referred to in paragraph 1 of this Article:

(i) A returned person who is arrested or detained shall be brought promptly before a judge or other officer authorised by law to exercise judicial power in order that the lawfulness of his detention may be decided;

(ii) A returned person who is arrested or detained shall be informed promptly of the reasons for his arrest or detention, and of the charges against him;

(iii) A returned person who is charged with an offence following his return shall receive a fair and public hearing without undue delay by a competent, independent and impartial tribunal established by law. Judgment shall be pronounced publicly, but the press and public may be excluded from all or part of the trial in the interests of morals, public order, or national security, where the interests of juveniles or the protection of the private life of the parties so require, or to the extent strictly necessary in the opinion of the court in special circumstances where publicity would prejudice the interests of justice;

(iv) A returned person who is charged with an offence following his return shall be allowed adequate time and facilities to prepare his defence, and shall be permitted to examine or have examined the witnesses against him and to call and have examined witnesses on his behalf. He shall be allowed to defend himself in person or through legal assistance of his own choosing, or, if he has not 
sufficient means to pay for legal assistance, shall be entitled to receive legal assistance in accordance with the law of the receiving State.

3. Where there are serious and credible allegations that a statement from a person has been obtained by torture or ill-treatment by the authorities of the receiving State and it might be used in a criminal trial in the receiving State referred to in paragraph 1 of this Article, then the statement shall not be submitted by the prosecution nor admitted by the Court in the receiving State, unless the prosecution submits evidence on the conditions in which the statement was obtained, and the Court is satisfied to a high standard that such statement has been provided out of free-will and choice and was not obtained by torture or ill-treatment by the authorities of the receiving State.

4. Where, before the date of signature of this Treaty, a Court in the sending State has found that there is a real risk that a statement from a person has been obtained by torture or ill-treatment by the authorities of the receiving State, and might be used in a criminal trial in the receiving State referred to in paragraph 1 of this Article, this statement shall not be submitted by the prosecution nor admitted by the Court in the receiving State, unless the prosecution in the receiving State proves beyond any doubt that the statement has been provided out of free-will and choice and was not obtained by torture or ill-treatment by the authorities of the receiving State, and the Court in the receiving State is so satisfied.

5. The guarantees set out in this Article shall apply to both:

(i) any retrial of a person returned to the Contracting States under this Chapter; and

(ii) any criminal trial on charges which have not previously been the subject of any criminal proceedings;

where those charges have been notified in accordance with Article 26(3). 